\title{
GEOLOGY, ENERGY AND MINERAL RESOURCES ASSESSMENT OF THE KITT PEAK AREA, ARIZONA
}

\author{
BY \\ SUSAN K. CRUVER, JACK CRUVER, A. WODZICKI AND JAN KRASON \\ GEOEXPLORERS INTERNATIONAL, INC. \\ 5701 East Evans Avenue \\ Denver, Colorado 80222 \\ Telephone 303-759-2746
}

Prepared for:

United States Department of the Interior BUREAU OF LAND MANAGEMENT

December 31, 1982

Gea-Scientific, Professional and Ongincering Services 
-

-

C 


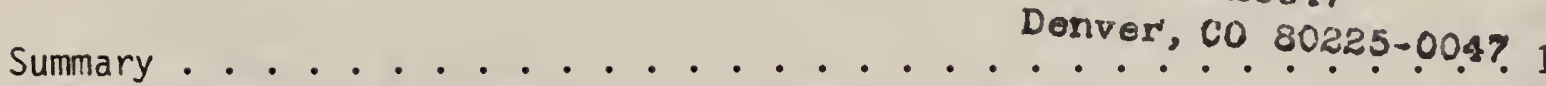

BLA Library

D-553A, Building 50

CONTENTS
Denver Federal Center

P. 0. Box 25047

Introduction. . . . . . . . . . . . . . . . . . 3

Purpose and methodology. . . . . . . . . . . . . . . 3

Location and access. . . . . . . . . . . . . . 3

Physiography. . . . . . . . . . . . . . . . . . . 5

Geology . . . . . . . . . . . . . . . . . . . . . 6

Lithostratigraphy-rock units . . . . . . . . . . . . 7

Precambrian . . . . . . . . . . . . . . . . 7

Paleozoic . . . . . . . . . . . . . . . 7

Mesozoic. . . . . . . . . . . . . . . . . 20

Lower Mesozoic supracrustal rocks. . . . . . . . . . .20

Jurassic plutonic rocks. . . . . . . . . . . . . . .22

Upper Mesozoic supracrustal rocks. . . . . . . . . .23

Laramide orogenic period. . . . . . . . . . . . . . 23

Metamorphic core complexes. . . . . . . . . . . . . 27

Mid-Tertiary. . . . . . . . . . . . . . . . . 30

Late Tertiary . . . . . . . . . . . . . . . . . 33

Latest Tertiary and Quaternary. . . . . . . . . . . 34

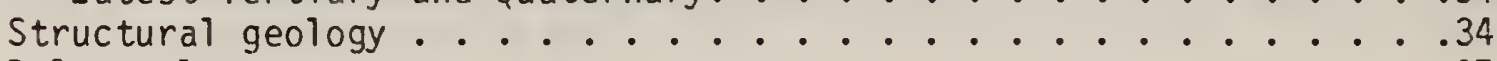

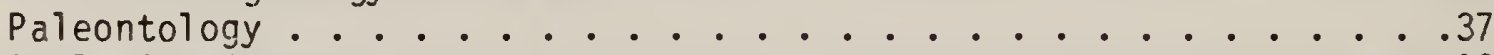

Geologic history . . . . . . . . . . . . . . . . . . . . . . . . . . .

Energy and mineral resources. . . . . . . . . . . . . . . . . 40

Known mineral deposits, mines or prospects

with recorded production. . . . . . . . . . . . . . . 41

known prospects, mineralized areas, and geothermal

resources with no recorded production . . . . . . . . .58

Mining claims, leases and material sites . . . . . . . . . . 65

Mineral deposit types. . . . . . . . . . . . . . . . . .66

Paleozoic and Mesozoic sediments. . . . . . . . . .66

Mesozoic plutonic rocks . . . . . . . . . . . . 70

Mesozoic volcanic rocks . . . . . . . . . . . . . . 71

Laramide intrusive rocks. . . . . . . . . . . . . . 71

Mid-Tertiary metamorphic rocks. . . . . . . . . . . . 73

Mid-Tertiary volcanics. . . . . . . . . . . . 75

Mid-Tertiary sediments. . . . . . . . . . . . . . .75

Late Tertiary sediments . . . . . . . . . . . . . . . . . . . . .

Recent alluvium .................... . . . . . . . . . . . .

Active geothermal systems . . . . . . . . . . . . . . . . . . .

Mineral economics. . . . . . . . . . . . . . . . . . . . . . . . . . .

Strategic and critical minerals and metals. . . . . . . . 79

The geology, energy and mineral resources of the

Wilderness Study Areas . . . . . . . . . . . . . . 80

Classification scheme. . . . . . . . . . . . . . . 80

Level of confidence scheme . . . . . . . . . . . . . . 84

The Coyote Mountains WSA (020-202) . . . . . . . . . . 84

Physiography. . . . . . . . . . . . . . . . . 84

Geology .. . . . . . . . . . . . . . . . . 84

Mineral deposits . . . . . . . . . . . . . . 85

Land classifiction for GEM resources potential. . . . . . . 86

Metallic minerals. ................. . . 86

Uranium. . . . . . . . . . . . . . . . . . . . . . . . . . .

Other resources. . . . . . . . . . . . . . 88

The Baboquivari Peak South WSA (020-203B)........... . . . . . . 


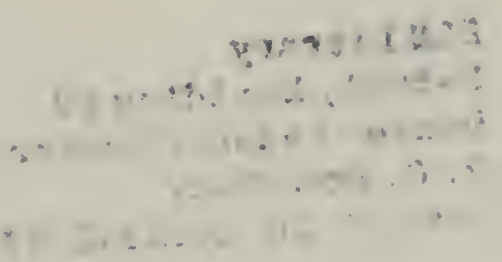

-

-

0 
Physiography. . . . . . . . . . . . . . . . . 88

Geology . . . . . . . . . . . . . . . . . 88

Mineral deposits. . . . . . . . . . . . . . . . . . . . . . . . . . .

Land classification for GEM resources potential . . . . . . .90

Metallic minerals. . . . . . . . . . . . . . 90

Uranium. . . . . . . . . . . . . . . . . 99

Non-metallic minerals. . . . . . . . . . . . .91

0ther resources. . . . . . . . . . . . . . . . . . . . . . . . . .

Recommendations for further work:

Coyote Mountains WSA (020-202) and

Baboquivari Peak South WSA $(020-203 B)$. . . . . . . . .91

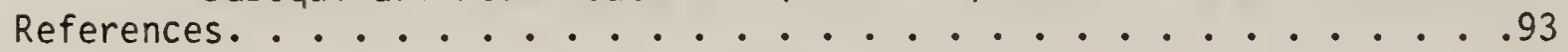

\section{ILLUSTRATIONS}

Figure 1: Physiographic map of south-central Arizona showing location of Sonora, Wymola and Kitt Peak areas.

Figure 2: Paleotectonic and paleogeographic maps of Arizona showing location of the Kitt Peak GRA.

Figure 3: Geologic, energy and mineral resources map of the Kitt Peak area, Arizona.

Figure 4: Legend for geologic, energy and mineral resources map.

Figure 5: Composit stratigraphic column of southwestern Arizona.

Figure 6: Claim density map, with oil and gas leasing status, of the Kitt Peak area, Arizona.

Figure 7: Location of oil and gas exploration holes in southern Arizona.

Figure 8: Favorability and level of confidence map for metallic mineral resources of the Kitt Peak area, Arizona.

Figure 9: Favorability and level of confidence map for uranium resources of the Kitt Peak area, Arizona.

Figure 10: Favorability and level of confidence map for non-metallic mineral resources of the Kitt Peak area, Arizona.

\section{TABLES}

Table 1: Wilderness Study Areas in the Kitt Peak GRA.

Table 2: Claim density records in the Wilderness Study Areas (WSA), Kitt Peak GRA.

Table 3: Geological environments of the Kitt Peak area and associated mineral deposit types. 
- 


\title{
GEOLOGY, ENERGY AND MINERAL RESOURCES ASSESSMENT OF THE KITT PEAK AREA, ARIZONA
}

\author{
by \\ Susan K. Cruver, Jack Cruver, Antoni Wodzicki and Jan Krason
}

\section{SUMMARY}

The Kitt Peak "Geological, Energy and Minerals (GEM) Resources Area" (GRA) lies within Pima County, Arizona and contains the following Wilderness Study Areas (WSAs):

Coyote Mountains (020-202), and

Baboquivari Peak South (020-203B).

Precambrian rocks do not occur in this part of Arizona. The oldest rocks which crop out in the area are Paleozoic shallow-water clastics and carbonates, which were thermally and regionally metamorphosed in the Laramide and mid-Tertiary. Mesozoic continental clastics and volcanics were deposited both before and after emplacement of voluminous Jurassic intrusives during the mid-Mesozoic orogeny, S-type granites were intruded during the Laramide and are associated with regional metamorphism of Paleozoic and Mesozoic sediments, and they may be associated with early stages of metamorphic core complex emplacement. The mid-Tertiary orogeny lasted from 35 to $14 \mathrm{~m} . \mathrm{y} . \mathrm{B} . \mathrm{P}$. and involved the following: Deposition of a thick sequence of fluvial and lacustrine sediments in northwest-striking downwarps; outpouring of calc-alkaline volcanics including ash-flow deposits possibly related to cauldrons; emplacement of metamorphic core complexes; and listric normal faulting which offset Mesozoic to mid-Tertiary volcanic and sedimentary rocks. Basin and Range faulting became dominant 14-4 m.y.B.P. and was accompanied by bimodal volcanism. Since 4 m.y.B.P. the main geological processes have been erosion and deposition of alluvium.

Geologic environments potentially favorable for the occurrence of mineral or energy resources in the WSA include: Paleozoic and Mesozoic sediments and metamorphosed equivalents; Mesozoic plutonic rocks; Mesozoic volcanic rocks; Laramide intrusive rocks; mid-Tertiary metamorphic rocks; mid-Tertiary volcanic rocks; mid- and late Tertiary sediments; and recent alluvium.

Numerous tungsten and polymetallic deposits are hosted by Paleozoic and Mesozoic sediments and are related to Laramide plutonism and metamorphism. Hydrothermal gold, silver and copper deposits are apparently associated with Jurassic plutonism. Mesozoic volcanic rocks host polymetallic deposits related to Cretaceous volcanism, Laramide plutonism, or mid-Tertiary metamorphic core complex emplacement. Laramide intrusives are related to hydrothermal gold-silver and base-metal deposits, tungsten and uranium mineralization, and beryl occurrences in pegmatites. Hydrothermal gold, silver, copper, lead and manganese mineralization is related to mid-Tertiary volcanics. Several tungsten, gold and silver placer deposits occur in Recent 
alluvium.

The Coyote Mountains WSA (020-202) is underlain by metamorphosed Paleozoic sediments, Jurassic and Laramide intrusives, Mesozoic sediments and volcanics, and Recent alluvium. The Coyote Mountains may represent a mid-Tertiary metamorphic core complex. One copper-bearing pyrometasomatic replacement deposit in the WSA is hosted by metamorphosed Paleozoic limestones. Molybdenum and uranium mineralization located near the WSA is probably related to Laramide plutonism. The WSA is of low to moderate favorability for the occurrence of metallic minerals and uranium.

The Baboquivari Peak South WSA (020-203B) is underlain by early and late Mesozoic volcanics and sediments, Jurassic granite and Laramide pegmatite. A silver and gold occurrence is located in the WSA and may be related to Laramide diking. Beryl occurs in Laramide pegmatites near the northern edge of the WSA. The WSA is considered moderately favorable for the occurrence of metallic minerals, of low favorability for the occurrence of uranium, and parts of the WSA and adjacent areas that are underlain by Laramide pegmatites are moderately favorable for the occurrence of nonmetallic minerals.

Important recommendations for further work in the WSAs include:

1. Large areas of the WSAs should be field checked for the occurrence of hydrothermal alteration that may be related to mineralization.

2. Geochemical sampling and analysis of rocks of the possible metamorphic core complex should be done to check for enrichment of several elements.

3. The uranium occurrence (U 14) located near the Coyote Mountains WSA should be field checked for mineralization and/or radioactivity.

4. Laramide pegmatites in the WSAs should be field checked for the occurrence of uranium and beryl. 


\section{INTRODUCTION}

\section{Purpose and Methodology}

The need for "Geological, Energy and Minerals (GEM) Resources Assessment" of "Wilderness Study Areas" (WSA) has been recognized for some time by the Bureau of Land Management (BLM). The assessment is now being performed by various contractors for the BLM.

Wilderness Study Areas, widely scattered within the Sonoran Desert and Mexican Highlands and grouped into Region 5 by the BLM, are being studied and assessed by Geoexplorers International, Inc. The present report pertains to two WSAs in southern Arizona which have been grouped together into the Kitt Peak Geological Energy and Minerals Resources Area (GRA).

The purpose of the present study is to assess the potential for locateable, leaseable and saleable resources within the GRA, and specifically within each of the WSAs. This assessment has been carried out through literature study of the geology, structure and economic geology of the GRA, with a consideration of the regional paleogeographic, plate tectonic and metallogenic setting of the GRA within the southern Cordillera. Thus, the assessment is not only based on data from the GRA itself, but also on metallogenic concepts within the regional paleogeographic and plate tectonic framework.

\section{Location and Access}

The Kitt Peak GRA is located in Pima County, southeastern Arizona. The GRA lies in the southwestern part of the Tucson 1:250,000 quadrangle and in the northwestern part of the Nogales 1:250,000 quadrangle. Arizona Highway 86 traverses the northern half of the area and Arizona Highway 286 traverses the eastern half of the Kitt Peak GRA (fig. 1). Numerous dry-weather and 
0 
light duty roads provide access to ranches and small towns in the valleys; some of these roads extend into the lower reaches of the Baboquivari Mountains. The Kitt Peak National Observatory is located in the north-central part of the GRA and the Papago Indian reservation occupies the western half of the area. No major towns are present in the GRA, but Tucson lies about 25 miles east-northeast of the Kitt Peak GRA. The two WSAs within the Kitt Peak GRA are described in Table 1.

\section{Table 1. Wilderness Study Areas in the Kitt Peak GRA}

WSA NO. WSA Name

Acres

$020-202$

Coyote Mountains

5080

$020-203 B$

Baboquivari Peak South

2065

Total

7145

\section{PHYSIOGRAPHY}

The GRA lies within the Sonoran Desert section of the Basin and Range Province of Fenneman (1931). The area has north-south and northeast-trending topographic grains reflecting Basin and Range faulting and, perhaps, lineation of a mid-Tertiary metamorphic core complex. Basin and Range fault scarps have eroded back to form extensive pediments and range fronts are embayed (Tucker, 1980). This is because much of southern Arizona has been almost free of tectonic activity for the past several million years.

The Kitt Peak GRA can be divided into two distinct physiographic terrains: mountainous - to - hilly and lowland terrains.

The mountainous - to - hilly terrain is comprised of the Baboquivari Mountains, Quinlan Mountains, Coyote Mountains, Bell Mountain, Dobbs Buttes and Martina Mountain, which trend north-south to northeast through the GRA, the southern Comobabi Mountains in the northwest corner of the GRA, Los 
r

$\bullet$

- 
Animas Mountain in the southwest part of the GRA, and Las Guijas Mountains in the southeast corner of the GRA.

Baboquivari Valley, in the western part of the area, and Altar Valley, in the eastern part of the GRA, comprise the lowland terrain. Both are probably fault-bound basins which have widened due to the formation of pediments. Both valleys are filled with more than 4800 feet of sediments.

\section{GEOLOGY}

Southern Arizona is an area of highly complex geology. Rocks range in age from Cambrian to Recent, and the area has been affected by mid-Mesozoic, Laramide and mid-Tertiary orogenies, and Basin and Range faulting. Important advances in the understanding of the complex geology of southern Arizona have been made since the publication of the Geologic Map of Arizona (Wilson et a1., 1969) and have been summarized by Reynolds (1980). These advances have largely been the result of a greatly increased number of radiometric dates (Haxel et al., 1980; Shafiqullah, et al., 1980); regional and local analyses of deformation (Davis, 1981; Gardulski, 1980; Davis et a1., 1981; Rehrig and Heidrick, 1967); recognition of metamorphic core complexes (Coney, 1980; Davis et al., 1981 and 1980; Rehrig and Reynolds, 1980; Davis and Coney, 1979); recognition of the relationship between subduction magmatism and metallogenesis in the southern Cordillera (Damon et a1., 1981; Coney and Reynolds, 1977); and an increased level of mapping of Cenozoic basins as a result of intense uranium exploration during the late 1970's (Scarborough and Wilt, 1979; Eberly and Stanley, 1978).

The lithology and stratigraphy, structural geology and tectonics, paleontology and geologic history of the Kitt Peak GRA are discussed in this section in order to facilitate the assessment of mineral potential within the GRA, and specifically, within the enclosed WSAs. The regional geologic 
setting is shown in figure 2 and detailed geology of the Kitt Peak GRA is illustrated in figure 3 .

\section{Lithostratigraphy-Rock Units}

In the kitt Peak GRA and adjoining areas of the Papago Indian Reservation, Precambrian rocks do not crop out. The oldest rocks in the GRA are Paleozoic shallow marine sediments, which have been engulfed by Laramide intrusives and penetratively metamorphosed; Mesozoic sediments, intrusives and volcanics; Laramide intrusives, sediments and metamorphic rocks; mid-Tertiary intrusives, volcanics and clastic continental sediments; 1ate Tertiary valley-fill and pediment-capping sediments and recent alluvium. Intense activity and metamorphism took place during the mid-Mesozoic, Laramide and mid-Tertiary. Metamorphic core complexes were probably emplaced during the latter event.

\section{Precambrian}

The Baboquivari Mountains, the central range of the Kitt Peak GRA, occupy an area of southern Arizona which contains no outcroppings of Precambrian rocks and few outcroppings of Paleozoic sediments (Wright and Haxe1, 1982; Haxel et a1., 1980). Radiometric data indicate that the aluminous Laramide Pan Tak pluton of the Coyote Mountains is probably derived from a Precambrian source (Wright and Haxe1, 1982; Haxel et a1., 1980).

\section{Paleozoic}

Three Paleozoic formations have been tentatively identified in the Coyote Mountains of the kitt Peak GRA. Sediments of the Cambrian Bolsa Quartzite and Abrigo Formation and the Devonian Martin Formation are present within the Laramide Pan Tak Granite (Gardulski, 1980). The Paleozoic sediments have been dilated and contact metamorphosed by the intrusion, then 
Figure 2: Paleotectonic and paleogeographic maps of Arizona showing location of the Kitt Peak GRA.

A. Location of Precambrian terrains and the Holbrook, Bright Angle-Mesa Butte and Colorado lineaments, after Warner (1978) and Titley (1982).

B. Location of mid-Mesozoic magmatic arc, the Mojave-Sonora megashear and mid- to late Mesozoic red beds, after Dickinson (1981). The red beds postdate the magmatic arc and probably extend farther to the southwest than shown.

C. Location and age trends of major porphyry copper deposits. Note that these are aligned parallel to northwest-trending Paleozoic-Mesozoic discontinuities (Lowe11, 1974; numbers 1-6 correspond to discontinuities named in Heidrick and Titley, 1982), along northwest-trending Laramide magmatic arcs ( $v$ pattern), and along northeasterly Precambrian trends (Heidrick and Titley, 1982). Curved black lines show location of arc at different times, as given.

D. Location of Precambrian alkali and alkali-calcic intrusions and mid-Tertiary metamorphic core complexes, mid-Tertiary alkali-calcic volcanics and sedimentary domains (Scarborough and Wilt, $1979)$. 


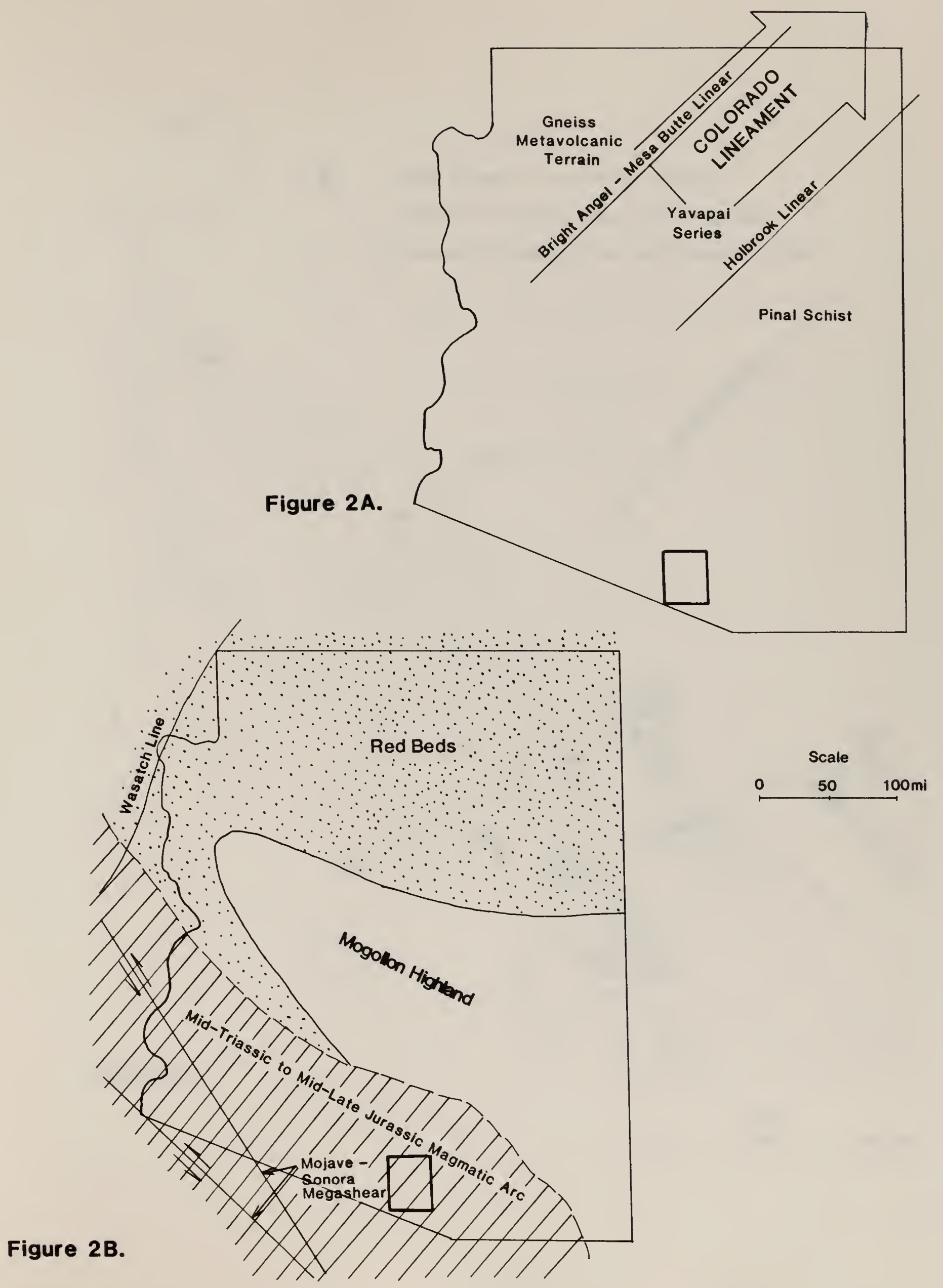




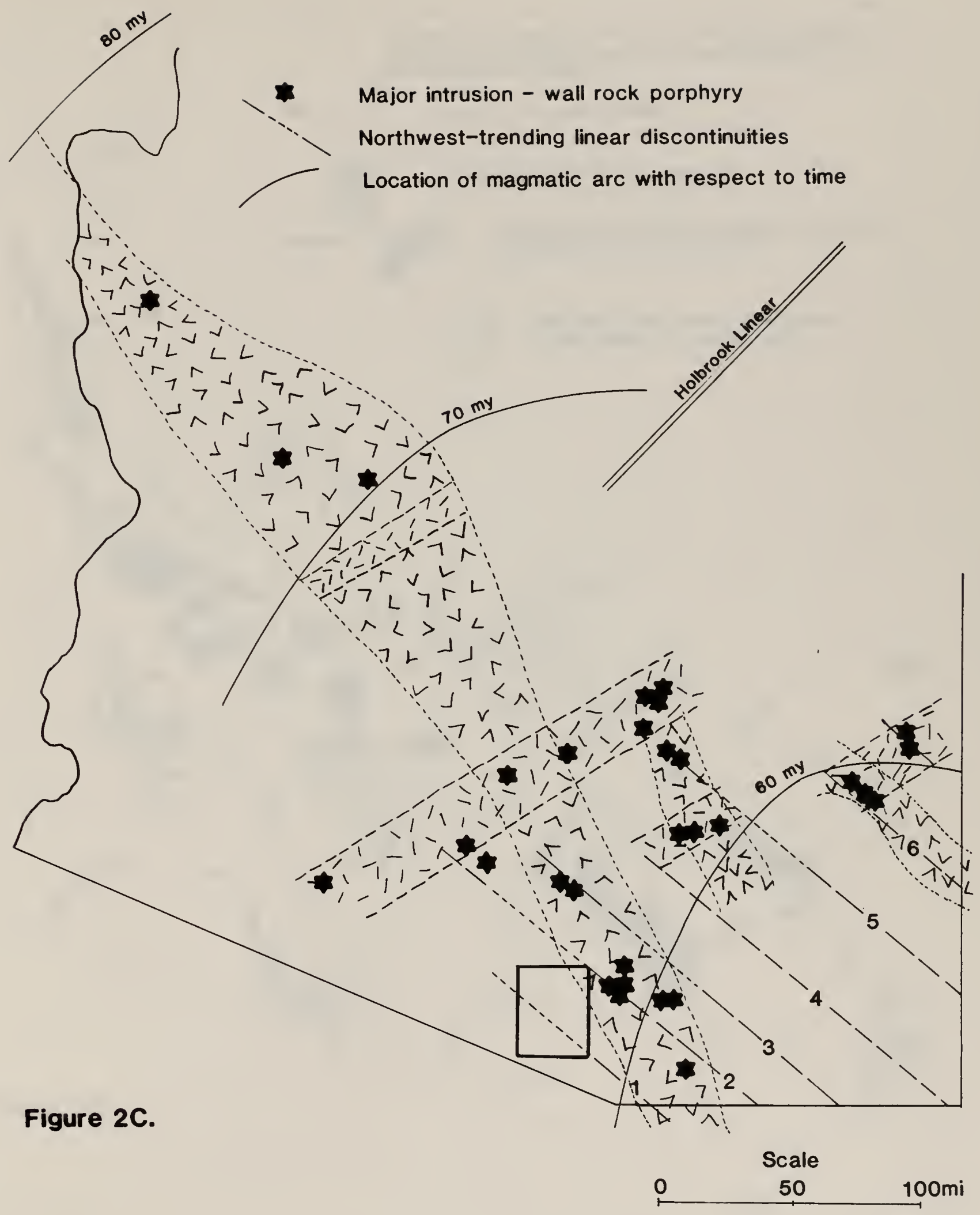




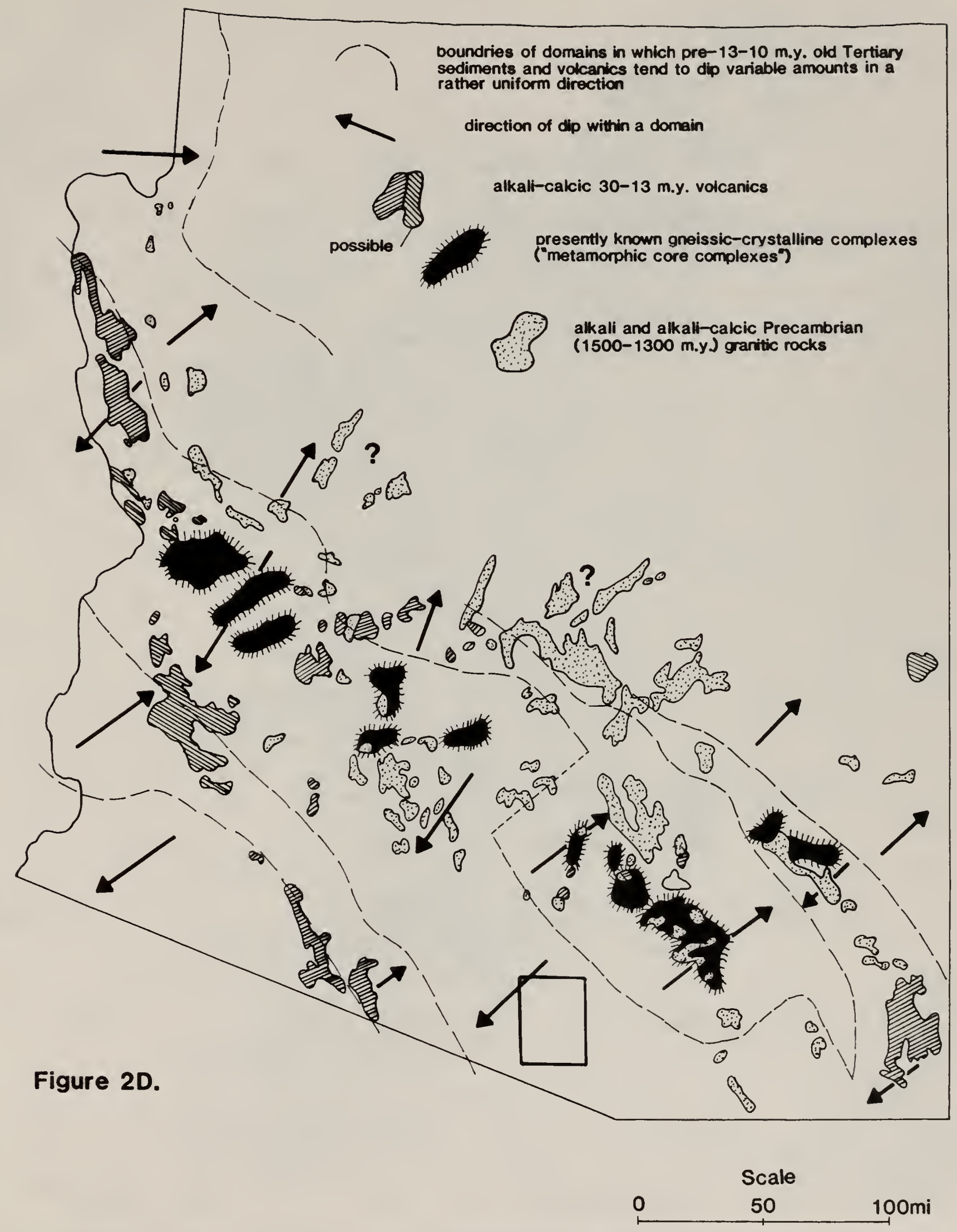


e 


\section{FIG. 3 GEOLOGIC, ENERGY AND MINERAL RESOURCES MAP OF THE KITT PEAK AREA, ARIZONA}




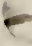

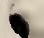


Figure 4.

GEOLOGIC, ENERGY AND MINERAL RESOURCES MAPS

Scale of all maps is $1: 250,000$ or as otherwise indicated. 
0

○

0 


\section{LITHOSTRATIGRAPHY}

After Wright and Haxel (1982), Haxel and others (1980), Gardulski (1980), Davis and others (1981), Wilson and others (1969), Heindl and Fair (1965), Heindl (1965), and Fair (1965).

QUATERNARY

\section{LATE TERTIARY TO QUATERNARY}

QTs

\section{Tvs}

\section{MID-TERTIARY}

\section{CRETACEOUS TO TERTIARY}

SEDIMENTS - Alluvium; mostly sand and silt.

SEDIMENTS - Dominantly gravels; includes alluvial fan and pediment deposits.

SILICIC VOLCANICS - Rhyolitic tuffs, agglomerates and possibly fluvlal clastlc rocks. Includes Kohi Kug Volcanics.

SEDIMENTS and VOLCANICS, undifferentiated.

INTERMEDIATE VOLCANICS - Andesite flows, breccias, and conglomerates of the Yellowstone Wash Formation in the Baboquivari Mountains and other units elsewhere in the area.

INTRUSIVES - Dikes, sills and possibly plugs and small epizonal plutons. Intermediate to silicic composition.

CONGLOMERATE - Possibly the Fresnal Fanglomerate; thick-bedded, red conglomerate.

METASEDIMENTARY ROCKS - Thermally and regionally metamorphosed equivalents of the Cambrian Bolsa Quartzite and Abrigo Formation and the Devonian Martin Formation. Calc-silicate rocks and quartzite tectonite.

METASEDIMENTARY AND METAVOLCANIC ROCKS - Greenschist facies metamorphic equivalents of the All Molina and Pitoikam Formations of Jurasslc (?) age. Phyllite, schist, semischlst, metaconglomerate, quartzite, metarhyolite, greenschist, mlnor gneisses.

GRANITC ROCKS OF PRESUMIDO TYPE - Alumlnous granitic rocks, including gamet-two-mica granites. Pan Tak Granite, Gu Chuapo Granite, Presumido Peak Granite and other unnamed plutons.

ROSKRUGE RHYOLITE - Rhyolite flows, tuffs, and agglomerates with Interbedded sediments and andesitic to dacitic flows. Dominantly pyroclastic in the Dobbs Buttes area.

ANDESITE - Undifferentlated andesite flows, tuffs and breccias; may include some sediments.

SEDMENTS-Undifferentiated continental clastic sediments; may contain lesser volcanics. Includes Sand Wells Formation in northem Coyote Mountalns. 
○

-

○ 
Mzv

MESOZOIC

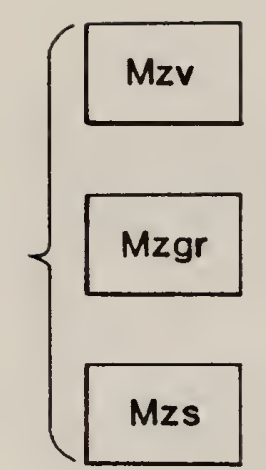

UPPER MESOZOIC VOLCANICS AND SEDIMENTS - Andesite to thyolite flows, tuffs. breccias and subvolcanic intrusives, and continental clastic rocks of the Chiull Shaik and Sand Wells Formations.

JURASSIC GRANITIC ROCKS - 165 to 145 m.y.B.P. granites to granodiorites with alkalic intrusives, diabases, and quartz diorites.

LOWER MESOZOIC SEDIMENTS AND VOLCANICS - Andesitic to thyodacitlc flows, tuffs and breccias, and continental clastics of the Ali Molina, Pitoikam, Mulberry Wash Volcanic, and Roadside Formations. 
○

0

○ 


\section{SPECIAL SYMBOLS \\ OF STRUCTURAL FEATURES \\ After U.S. Geological Survey}

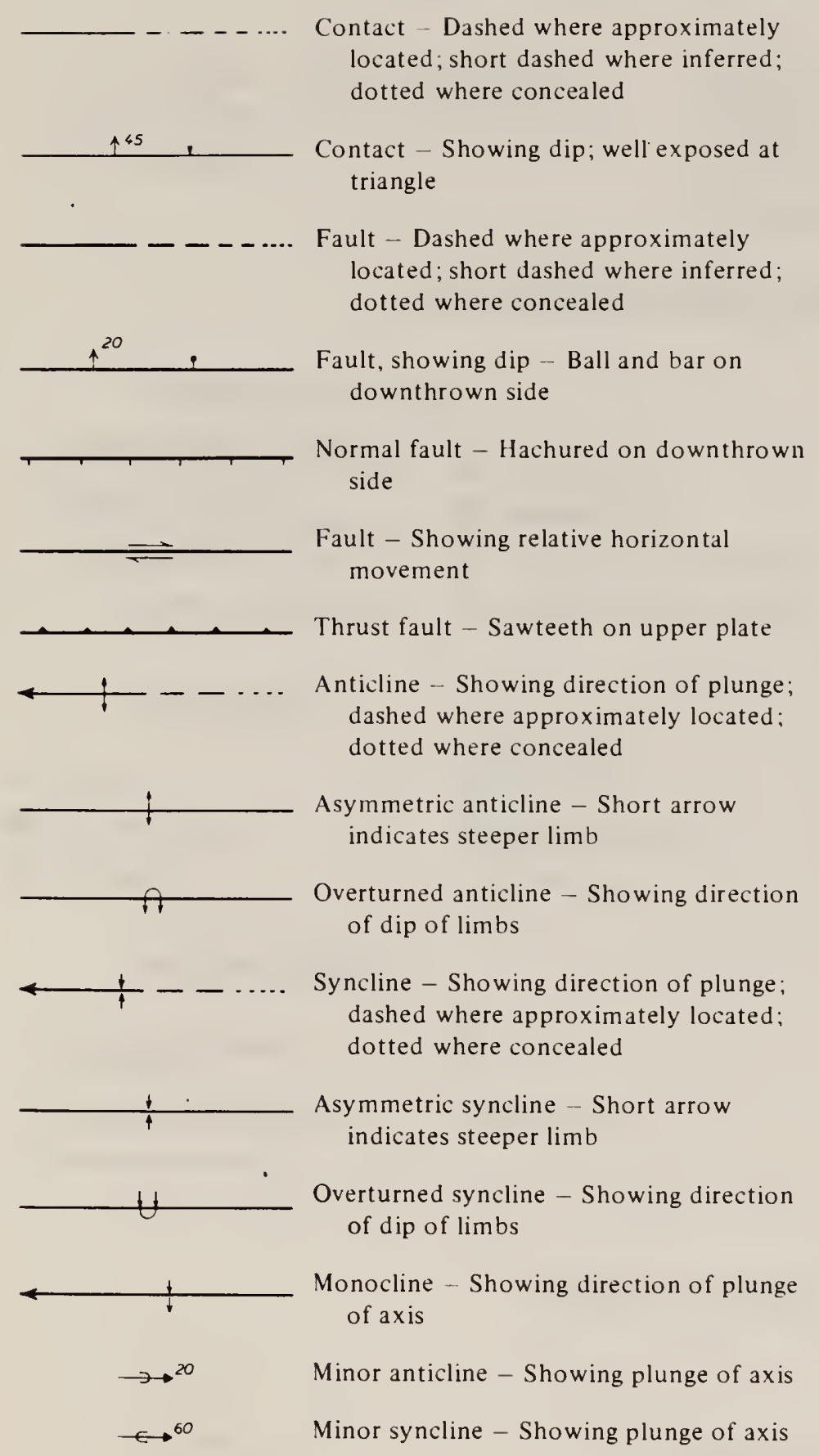

Strike and dip of beds - Ball indicates top of beds known from sedimentary structures

$\overbrace{}^{70}$ Inclined $\oplus$ Horizontal

+ Vertical ${ }^{40}$. Overturned

Strike and dip of foliation 20 Inclined † Vertical † Horizontal

Strike and dip of cleavage 15 Inclined $\longrightarrow$ Vertical If Horizontal

Bearing and plunge of lineation

$15 \&$ Inclined - Verlical $\longleftrightarrow$ Horizontal

Strike and dip of joints

${ }_{-}^{40}$ Inclined - Vertical - Horizontal

Note: planar symbols (strike and dip of beds, foliation or schistosity, and cleavage) inay be combined with linear symbols to record dat a observed at same locality by superimposed symbols at point of observation. Coexisting planar symbols are shown intersecting at point of observation. 
○

-

0 


\section{SPECIAL SYMBOLS}

\section{FOR ENERGY AND MINERAL RESOURCES}

\section{KNOWN DEPOSITS AND OCCURRENCES}
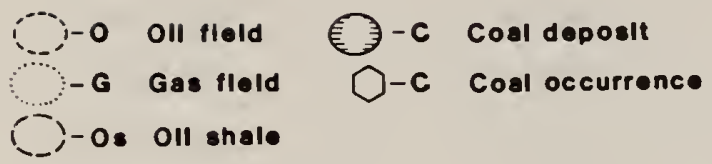

-Mineral orebody - as speclfled with symbol

- Mineral deposit - as speclfled with symbol

$\square$-Mineral occurrence - as specifled with symbol

a - Mineral dlstrlct (Fig. = Inserted map)

\section{EXPLORATION AND/OR MINING ACTIVITY}

\section{MINERALS AND COAL}

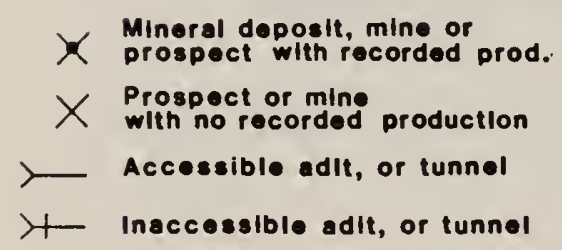

\section{PETROLEUM}

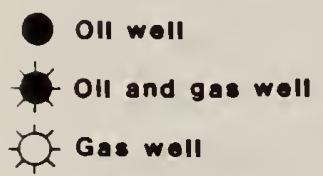

\section{GROUND WATER}

1 water well of speclal importance

$\downarrow$ water well of high yield

flowing water well

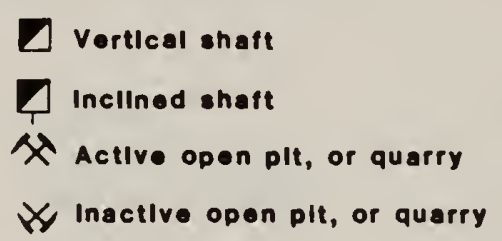

A Thermal point

\section{ENERGY RESOURCES}
o OII
G Gas
Os Oll shale
Ot Tar sands

C Coal

U Uranium

Cb Lignite (brown coal)

Cp Peat

Th Thorlum

Gt Geothermal 
-

-

0 


\section{MINERAL RESOURCES}

\section{METALS}
Al Aluminum
Sb Antimony
As Arsenic
Be Beryilium
Bi Bismuth
Cd Cadmium
Cr Chromium
Cs Cesium
Co Cobait

Cu Copper

Ga Galilum

Ge Germanium

Au Gold

Fe iron

Pb Load

LI Lithium

Mn Manganese

Hg Mercury

Mo Molybdenum
Ni Nickel
Nb Nioblum or Columblum
Pt Piatinum group
RE Rare earth
Re Rhenium
SC Scandium
Ag Silver
T• Teliurium

TI Thallium

Sn Tin

Ti Titanium

w Tungston

v Vanadium

Zn Zine

$\mathrm{Zr}$ Zirconium and Hf Hafnium

\section{NONMETALS - INDUSTRIAL MINERALS}

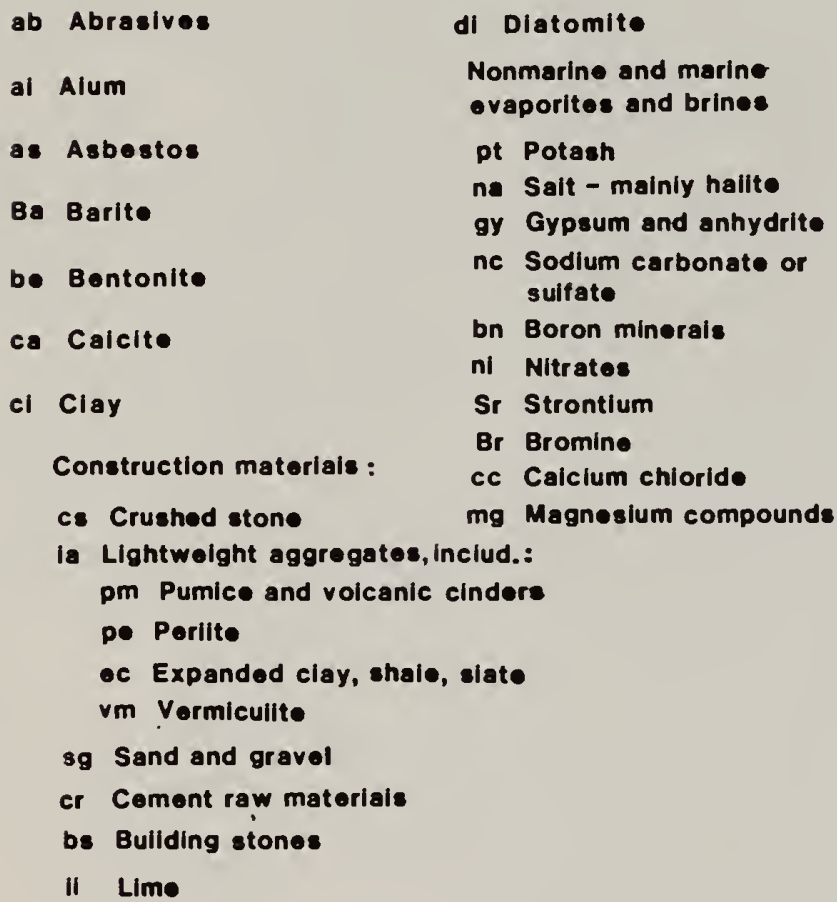

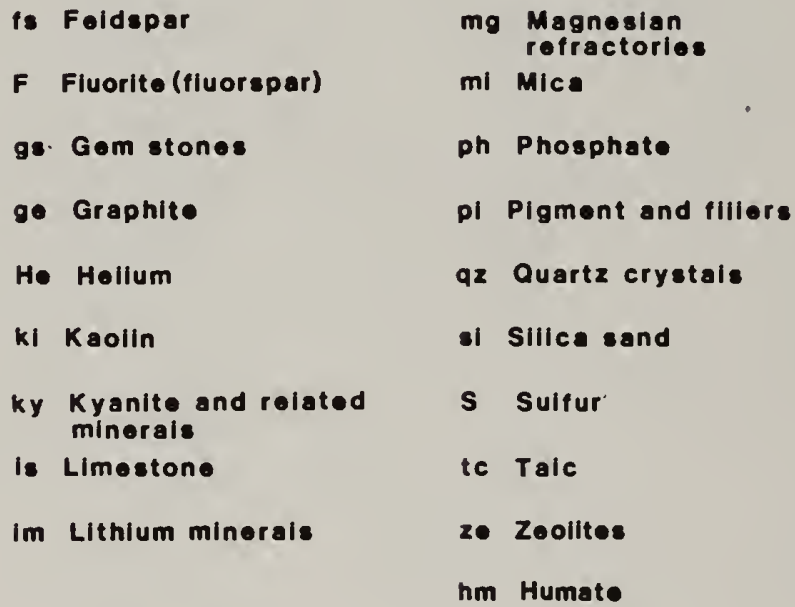




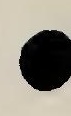

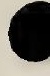

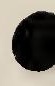




\section{SPECIAL GEOLOGICAL FEATURES}

POINT OF SPECIAL GEOLOGIC INTEREST

m Mineral occurrence

f Fossil locality

v Volcanic phenomenon

t Stratigraphic sequence
- Structural, bedding, follation, etc.,

b Brecciation, shear zone, etc.,

y High yieid sping

p Spring with mineral water u Radioactive epring

g Thermal spring

Extensive rock alteration

r Lthologic type loceilty

\section{FAVORABILITY POTENTIAL AND LEVEL OF CONFIDENCE FOR MINERAL RESOURCES}

\section{FAVORABILITY:}

$1 A$ - Undefined

1 - Not favorable - combine with elther B, C, or D

2 - Low

3 - Moderate

4 - HIgh

\section{LEVEL OF CONFIDENCE:}

A - Insufficient data

B - indirect evidence

C - Direct evidence

D - Abundant direct and Indirect evidence 
-

○

○ 
penetratively metamorphosed by a later event, and parts of the section subsequently underwent cataclastic metamorphism during the mid-Tertiary orogeny. As the Paleozoic formations retain little similarity to their unmetamorphosed counterparts which crop out el sewhere in southern Arizona, they will be discussed in a following section describing Laramide-age rocks.

\section{Mesozoic}

Mesozoic rocks of the Baboquivari Mountains and adjoining areas have been divided into three broad units by Haxel and others (1980). These units are as follows: lower Mesozoic supracrustal rocks, which are older than to coeval with Jurassic intrusives; mid- to late Jurassic plutonic rocks; and upper Mesozoic supracrustal rocks, which were formed after the mid-Mesozoic orogeny and prior to the Laramide orogeny.

\section{Lower Mesozoic Supracrustal Rocks}

Lower Mesozoic supracrustal rocks crop out in the north-center, center and northwest portions of the Kitt Peak GRA and underl ie parts of both the Coyote Mountains and Baboquivari Peak South WSAs. From oldest to youngest, the lower Mesozoic rocks of the Baboquivari Mounains (central part of the GRA) are: the Ali Molina Formation, the Pitoikam Formation and the Mulberry Wash Volcanic Formation. The Roadside Formation, which is not correlative with the formations of the Baboquivari Mountains, crops out in the northern part of the GRA.

The lower Jurassic Ali Molina Formation has been divided into two parts by Haxel and others (1980). The lower part is comprised of tan to white rhyodacitic flows, tuffs and pyroclastics with lesser porphyritic andesite. Interbedded with the volcanics are quartzite and arkosic quartzite. The upper part of the Ali Molina Formation is sandstone and conglomerate (Haxel et al., 1980; Fair, 1965). The Ali Molina Formation is about 12,000 feet 
○

○

- 
thick (Haxel et al., 1980).

Overlying the Ali Molina Formation, in probable conformable contact, is the lower Jurassic Pitoikam Formation. Thickness of this formation, which Haxel and others (1980) have divided into three members, is not reported. The unnamed lower member is composed of red to maroon conglomerate, brown and white sandstone and purple and green siltstone. The middle unit is the Contreras Conglomerate Member, which is volcaniclastic conglomerate with minor interbedded sandstone and siltstone. The Chiltepines Member rounds out the section. This upper member consists of siltstone with subordinate shale, sandstone, conglomerate, and at the top, intermediate volcanic flows (Haxel et al., 1980). Fair (1965) reports a tan to white limestone in the upper part of the section.

The lower Jurassic Mulberry Wash Volcanic Formation unconformably overlies the Pitoikam Formation. The lower part of the 5000 foot thickness of Mulberry Wash rocks consists of gray, pink and red porphyritic rhyodacitic to andesitic flows intertonguing with volcanic breccia, lesser flows and small lenses of arkose and shale. The middle unit is predominantly red to brown volcanic breccia to conglomerate with lesser green-gray arkose, green mudstone, white marl and local limestone. The upper part is composed of purple to red latitic, rhyodacitic and andesitic flows with lesser breccias and tuffs (Haxel et al., 1980; Fair, 1965).

The Roadside Formation is the lower Mesozoic unit which crops out in the northern part of the GRA. The lower part of the Roadside Formation is comprised predominantly of dacitic flows with interbedded clastics ranging from mudstone to boulder conglomerate and breccia. Clasts in the coarse-grained rocks include arkose, quartzite, andesite, limestone, schist and granite. The upper part of the Roadside Formation is made up of andesite flows and breccias, with lesser brecciated limestone lenses (Heind1, 1965). 
-

-

- 


\section{Jurassic Plutonic Rocks}

Mid- to late Jurassic intrusives ranging in age from 165 to 145 m.y.B.P. underlie much of the Baboquivari Mountains and also crop out in the South Comobabi Mountains in the northwest part of the GRA. Most of the rocks are quartz-rich and range from alkali feldspar granite to granodiorite with alkalic intrusives occurring in the Comobabi Mountains.

The Kohi Kug Granite is described by Fair (1965) as a brick red to tan porphyritic granite associated with dark gray diabase and pods of gray, equigranular monzonite. The Kohi Kug Granite apparently crops out in the northern Baboquivari Mountains.

The Otero Granite of the Baboquivari Mountains is a medium-grained, gray, quartz- and biotite- bearing porphyry. The Baboquivari Granite crops out at Baboquivari Peak and in the western part of the range and is a coarse-grained, reddish, porphyritic rock with large phenocrysts of potassium feldspar and clusters of chlorite (Heindl and Fair, 1965). Granodiorite, quartz monzonite and quartz diorite intrusives occur in the Quinlan Mounains of the north-central part of the GRA (Min, 1965).

Wright and Haxel (1982) and Gardulski (1980) described the Jurassic intrusives of the Coyote Mountains. Four units crop out in the southern part of the mountains: sphene-bearing hornblende-biotite and biotite granodiorite and monzonite, both intruded by biotite monzogranite and syenogranite. Mesocratic sphene- and epidote- bearing biotite-hornblende quartz diorite, hornblende-epidote diorite and augite hornblendite crop out in the northeast Coyote Mountains. Gardulski (1980) notes that some of the northern rocks have glomeroporphyritic texture with clots of chlorite, some with pyroxene cores. 
-

c 


\section{Upper Mesozoic Supracrustal Rocks}

Upper Mesozoic units of the Kitt Peak GRA are dominantly sedimentary with lesser volcanics. The Chiuli Shaik Formation, of late Jurassic or Cretaceous age, crops out in the central and southern parts of the GRA. It is composed of 2000 feet of andesite flows, breccias, rhyolite tuffs and subvolcanic intrusions (Haxel et al., 1980; Heindl and Fair, 1965). The Sand Wells Formation of probable cretaceous age, but possible late Jurassic age, crops out in the southern Comobabi Mountains and in the northernmost part of the Coyote Mountains. The Sand Wells Formation is about 1900 feet thick in the southern Comobabi Mountains and is composed of a basal conglomerate overlain by a middle unit of sandstone, siltstone, conglomerate, mudstone and subordinate volcanics. The upper part of the Sand Wells consists of volcanic breccia and flows of intermediate composition, with minor sandstone beds (Haxel et al., 1980). The Roskruge Rhyolite crops out over much of the northeast part of the area and is composed of rhyolite flows, tuffs and agglomerates with intercalated sediments and andesitic to dacitic flows. In the Dobbs Buttes area, the 1250 feet of the Roskruge Rhyolite is dominantly pyroclastic and is interbedded with water-laid tuffaceous sediments. The Cretaceous unit unconformably overlies the Roadside formation but nowhere is in contact with rocks of the Sand Wells Formation (Heindl, 1965).

\section{Laramide Orogenic Period}

The Laramide was a period of volcanism, intrusion and intense tectonic activity in southern Arizona. It is of particular importance because a large number of porphyry copper deposits were formed at this time, especially in southeastern Arizona (Damon and Mauger, 1966; Shafiqullah et al., 1980; Titley, 1981; Heidrick and Titley, 1982; see fig. 2C). Of the 35 major porphyry copper deposits in Arizona, 32 1ie to the southeast of the Holbrook 
-

-

○ 
Line where basement is Pinal Schist, and 3 lie to the northwest where basement consists of Yavapai Series and gneissic-metavolcanic terrain (see figure 2 C). The intrusives associated with the porphyry copper deposits were emplaced during the southeastward sweep of the magmatic arc (Damon et al., 1981; Clark et al., 1982) and possibly are related to the decrease in the dip of the Benioff zone at this time (Coney and Reynolds, 1977). The porphyry copper deposits appear to be aligned along northwest and east-northeast trends (see figure 2C; Heidrick and Titley, 1982). The northwesterly trend is sub-parallel to Mesozoic linear discontinuities in depostional patterns (Titley, 1976); the trend of Laramide basement-cored uplifts and faults (Nielsen, 1979; Davis, 1981); the Texas zone of Schmitt (1966); and the trend of the Laramide magmatic arcs. The ENE-trend is sub-parallel to Precambrian fold axes and to Laramide tensional fractures (Rehrig and Heidrick, 1976). The intrusions related to the porphyry copper deposits are small in area (seldom over $3 \mathrm{~km}^{2}$ ) and may have been emplaced along the NW and ENE structural intersections (Titley, 1982).

Intrusives, metamorphic rocks and possibly sediments of Laramide age occur in the Kitt Peak GRA. Laramide intrusive rocks crop out in the Las Guijas Mountains in the southeast corner of the GRA, through most of the length of the Baboquivari Mountains, in the Coyote Mountains in the northeast and the Quinlan Mountains and South Comobabi Mountains in the northwest. Metamorphic rocks crop out in the South Comobabi Mountains, the Coyote Mountains and the Baboquivari Mountains in the southern part of the GRA. Conglomerate which may be Laramide or younger in age crops out northwest of Baboquivari Peak (see fig. 3 ).

Laramide granitic rocks of the Kitt Peak GRA and adjoining parts of the Papago Indian Reservation have been termed by Haxel and others (1980) as "granites of Presumido type" after granites of Presumido Peak, an area in the 
-

-

- 
Baboquivari Mountains south of the GRA. The Presumido Peak granite crops out in a small area at the southern edge of the GRA and is a garnet-two-mica granite. These highty aluminous granites are comparable to S-type granites, thought to be of sedimentary origin by Chappell and White (1974).

Haxel and others (1980) noted characteristics of the leucocratic muscovite- and garnet-bearing granites of the Presumido type, as follows:

1. The rocks have no hornblende, but contain all combinations of biotite, white mica and garnet. In Arizona, Laramide intrusives associated with porphyry copper deposits are all hornblende-bearing.

2. Most of the Presumido type granites were emplaced as two phase intrusions; the older phase contains little or no garnet, but the younger, highly leucocratic phase has sparse to common garnet and grade into or consist largely of pegmatite.

3. Most Presumido type rocks are monzogranites in composition and are not associated with hornblende-bearing rocks - the rocks are not part of a differentiation sequence. Intrusive contacts are sharp.

Wright and Haxel (1982) also note a strong spatial relationship between these aluminous granites and regionally meamorphosed rocks of the same age.

The $58 \pm 3$ m.y. old Pan Tak granite of the Coyote Mountains intrude Jurassic granites and diorites in the northeast and southwest, and Paleozoic sediments of the Bolsa Quartzite, Abrigo Formation and Martin Formation form a discontinuous septum running north-south down the center of the pluton (Wright and Haxe1, 1982; Davis et al., 1980b, Gardulski, 1980). It fits all characteristics of Presumido type granites. The younger phase is garnetiferous and composed almost entirely of pegmatites, with aplite dikes also ocurring (Wright and Haxel, 1982). 
-

-

- 
The Gu Chuapo granite of the northwest Quinlan Mountains and southeast Comobabi Mountains is also a garnet-two-mica granite but grades into granite porphyry.

Linear-shaped Laramide intrusives which stretch from the Quinlan Mountains south through the Baboquivari Mountains contain beryl-bearing pegmatites.

No information is available on the Laramide intrusive of the Las Guijas Mountains in the southeastern corner of the GRA.

Paleozoic sediments of the coyote Mountains have a fairly complex metamorphic history. In addition to contact metamorphism resulting from intrusion, the sediments have been affected by more than one penetrative deformational event. Garnet, epidote, K-feldspar, diopside, dolomite, muscovite and ubiquitous quartz are metamorphic phases which occur in several assemblages in metamorphosed limestone. Quartzites are visibly lineated. An early regional metamorphism foliated all rocks younger than the second phase of the Pan Tak pluton (Gardulski, 1980). As the Coyote Mountains were greatly affected by the mid-Tertiary orogeny, metamorphic history of the rocks will be discussed more completely in a following section.

Greenschist fascies regional metamorphism affected the Mesozoic rocks of the Ali Molina and Pitoikam Formations. These rocks, termed the metamorphic rocks or schist of Chutum Vaya, crop out in a large zone in the southern part of the GRA. A gradational contact exists between the Mesozoic rocks (Mzs) and the Laramide schist (TKSC) at the northern end of the schist body schists can be traced laterally into relatively unmetamorphosed Mesozoic parent rock. Metamorphic rocks of Chutum Vaya consist of quartzofeldspathic to quartzose phyllite and schist, arkosic semischist, epidotized sandstone, metaconglomerate, quartzite, metarhyolite, greenschist and some gneissic rocks. Foliation is predominantly westward-dipping and lineation plunges 
-

- 
gently to moderately NNW to NE. Kink folds and crenulations also occur (Haxel et al., 1980).

Laramide metamorphics of unknown nature are associated with garnet-two-mica granites of the Quinlan Mountains and South Comobabi Mountains. Laramide intrusives in the Kitt Peak GRA are both synmetamorphic and post-metamorphic (Haxel et al., 1980).

Haxel and others (1980) report that conglomerates (TKs, fig. 3) are either Laramide or younger in age. These conglomerates may be the thick, red Fresnal Fanglomerate of Fair (1965). Age of the unit, which rests unconformably on Mesozoic volcanics and sediments and is overlain by mid-Tertiary rocks, cannot be well-bracketed. It is quite possible that the conglomerate is part of a post-Laramde molasse-type deposit.

\section{Metamorphic Core Complexes}

More than a dozen metamorphic core complexes have been identified and described recently in southwestern Arizona. They occur along a northwest-trending zone that extends from southeastern to west-central Arizona and are part of a more extensive zone that runs from Sonora to Arizona, through eastern Nevada, Idaho, eastern Washington and southeastern British Columbia (Coney, 1980). Their general features have been summarized recently by Davis and Coney (1979) and Reynolds (1980) as follows. Metamorphic core complexes are characterized by metamorphic and mylonitic rocks whose gently dipping foliation defines broad domes which generally are elongated in an ENE to NE direction. The core of the domes consist of amphibolite facies gneisses and granites that have undergone ductile deformation. Up section a mylonitic fabric with an ENE-to-NE lineation is overprinted on both igneous and metamorphic rocks. This grades upward into a greenschist facies breccia over a short distance and records a sharp thermal 
-

-

• 
and strain gradient. The breccia is overlain by a normal decollement zone, or dislocation surface, above which allochthonous, deformed, but unmetamorphosed upper plate rocks are present. These range in age from Precambrian to Miocene and have undergone listric normal faulting as recently as mid-Miocene. The core complexes typically record $30-20$ m.y.B.P. K-Ar cooling ages. It is generally agreed that the complexes formed in an extensional environment (back-arc spreading?) during and after the fast regression of the magmatic arc $40-20 \mathrm{~m} \cdot y \cdot B . P$. (Coney and Reynolds, 1977) at a time of high heat flow. Davis and Coney (1979) regard the complexes as megaboudins formed from the crystalline basement. Rehrig and Reynolds (1980) agree that the complexes formed by an extensional process but consider that the metamorphic core complex itself developed between, rather than within, separating blocks.

Rocks of the Coyote Mountains, and a "sister" complex of rocks in the Pozo Verde Mountains approximately five miles south of the GRA, possess a number of characteristics common to metamorphic core complexes.

The rocks of the Pozo Verde Mountains include garnet-two-mica granites which intrude dominantly Mesozoic rocks. $100 \mathrm{~km}^{2}$ of the area has been metamorphosed into a mylonitic tectonite, with foliation dipping south. Between the Pozo Verde Mountains and the Coyote Mounains is non-mylonitic country rock protolith of the Baboquivari Mountains. K-Ar cooling age of muscovite associated with the metamorphic event in the Pozo Verde Mountains is 24 m.y.B.P. (Davis et al., 1981).

Widespread in Jurassic intrusive rocks and Paleozoic sediments and common in the older phase of the Pan Tak granite is west- to SW-dipping foliation with subordinate west- to WSW-dipping lineation. This metamorphism was contemporary with intrusion of the older phase of the Pan Tak Granite (Wright and Haxel, 1982). A later metamorphic event in the Coyote Mountains 
-

$\bullet$ 
produced penetrative NE-dipping foliation and NNW-plunging lineation in metaquartzites and discrete, NE-dipping, curviplanar slip surfaces in the pegmatite, part of the younger phase of the Pan Tak Granite, that encloses the metasedimentary rocks (Gardulski, 1980). Gardulski (1980) suggests that this ductile shear resulted from plastic flow accompanying flattening and NNW extension. The penetratively metamorphosed rocks are truncated by the Ajo Road Fault or Decollement (see fig. 3), a north-dipping normal fault. At least a one hundred meter thickness of Coyote Mountain rocks has a brittle, mylonitic foliation, associated with movement along the fault, which overprints the ductile deformation. A zone of chloritic breccia directly underlies the fault. A Tertiary dike emplaced after the ductile deformational event is truncated by the Ajo Road Decollement, suggesting a deformational hiatus between the penetrative event and activation of the decollement (Gardulski, 1980). Hanging wall rocks north of the fault are volcanics and sediments of the Mesozoic Roadside and Sand Wells Formations. The Mesozoic rocks are brittly deformed, with fracturing, faulting and shearing common. Adjacent to the fault, brittle deformation is intense and the rocks are shattered and have a pasty, gouged appearance (Gardulski, 1980; Davis et al., 1981).

Rocks of the Coyote Mountains, with north-dipping mylonitic foliation, and Pozo Verde Mountains, with south-dipping foliation, are unusual for core complexes as a very large mass of rocks (around 25 miles in length) that were unaffected by mid-Tertiary metamorphism separate the two areas. The Coyote and Pozo Verde Mountains certainly were greatly affected by the mid-Tertiary orogeny, but may not be metamorphic core complexes, at least as currently defined. 
0

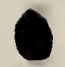

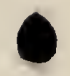




\section{Mid-Tertiary}

Mid-Tertiary rocks are here defined to include all sedimentary and igneous rocks deposited after the Laramide orogeny and the post-Laramide period of peneplanation, and before Basin and Range-type faulting became dominant. These pre-Basin and Range rocks have been divided into three units by Eberly and Stanley (1978) and Scarborough and Wilt (1979), and stratigraphy of the units is summarized in figure 5 .

The lowest unit consists of indurated, red to brown arkosic fluvial sandstone, fanglomerates of gneissic and granitic provenance up to 300 feet thick, and minor lacustrine sediments with some algal limestone. Andesitic to rhyolitic volcanics increase in abundance towards the upper part of this unit.

The middle unit is characterized by voluminous intermediate to felsic volcanism that is associated with the mid-Tertiary orogeny. The volcanics consist of flows, ash flow tuffs, tuff breccias and ash of latitic, quartz latitic, rhyolitic, and trachytic composition and flows and flow breccias of basaltic, basaltic andesite, and andestitic composition (Reynolds, 1980). Small intrusions of the above compositions are also present. The volcanic rocks are interbedded with red sand and gravel fluvial deposits, massive fanglomerates, and lacustrine deposits with local organic-rich facies, algal linmestones, and water-laid tuffs. It is within such beds that the well-known uranium deposit of the Anderson Mine is located (Sherborne et al., 1979).

The upper unit consists of grayish brown, poorly consolidated sandstones, fanglomerates, mudstones, and water-laid tuffs. The rocks contain abundant volcanic debris. They are overlain and intercalated with basaltic volcanic mudstones in lacustrine deposits and contain fresh water 
0

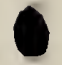

- 
PHOENIX-TUCSON AREA

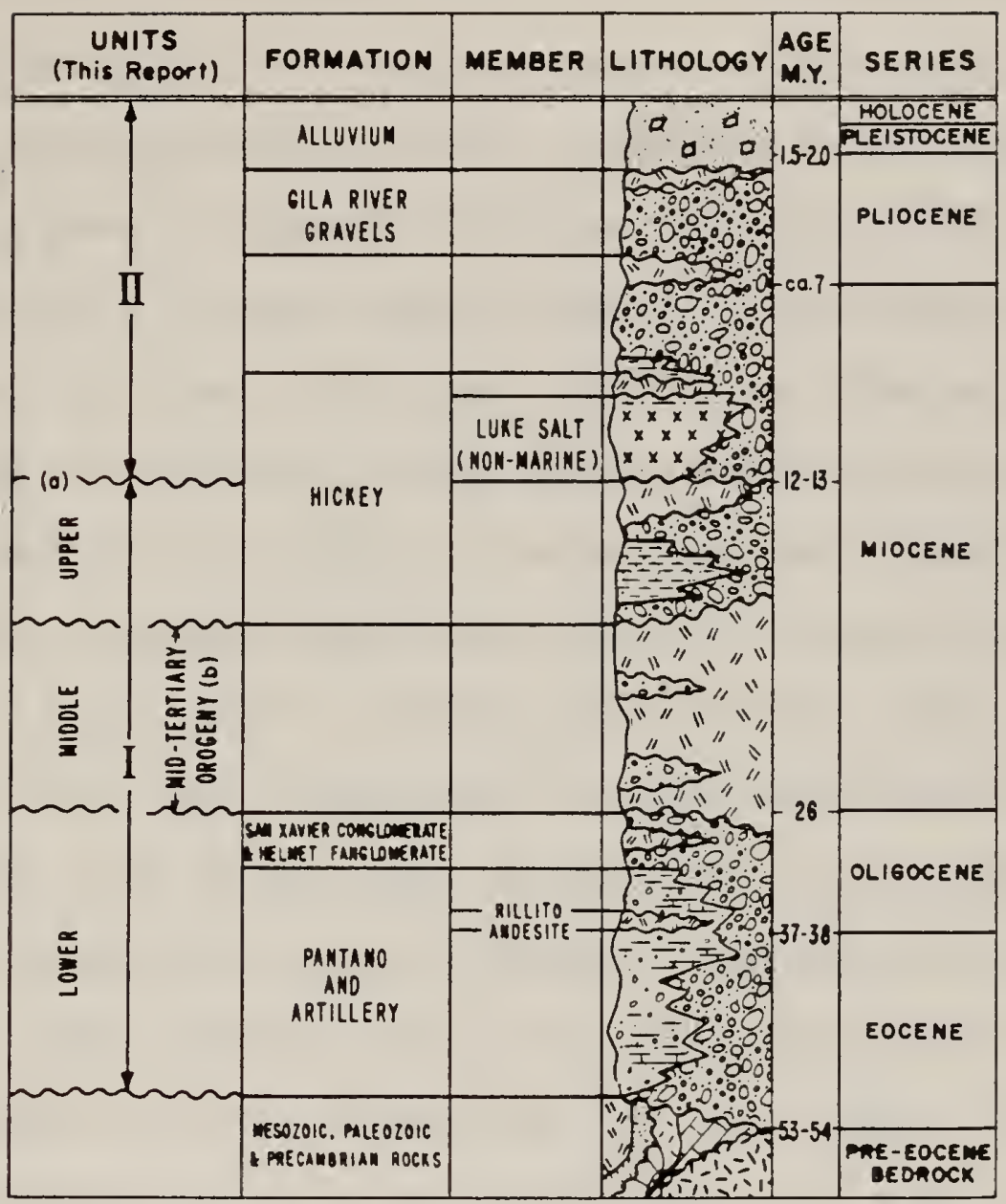

FIG.5 COMPOSITE STRATIGRAPHIC COLUMN OF SOUTHWESTERN ARIZONA. Unconformity (a) represents erosional surface that was disrupted by beginning of late Miocene block faulting. From Eberly and Stanley (1978). 


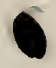

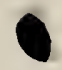

0 
ostracods.

The mid-Tertiary rocks of Arizona rest unconformably on Precambrian, Paleozoic, Mesozoic, and Laramide rocks. In the Kitt Peak GRA, mid-Tertiary rocks rest unconformably on Mesozoic sediments and volcanics. They were deposited in northwest-striking basins which were tilted northeastward and southwestward as shown in figure 2D (Scarborough and Wilt, 1979).

The mid-Tertiary volcanic rocks lie mainly in the middle unit, but they do extend into the lower and upper units. The volcanism was extremely voluminous, and in southern Arizona about a million cubic kilometers were emptied (Shafiqullah et al., 1980). These may have been largely emptied from cauldrons such as have been identified in the Datil volcanics in southwestern New Mexico by Elston (1978) and Elston and Bornhorst (1979). However, no such cauldrons have been identified in southwestern Arizona to date. The volcanism lasted from $35 \mathrm{~m} \cdot y \cdot B . P$. to about $12 \mathrm{~m} . y . B . P .$, with the interval between 24 and 12 m.y.B.P. being the transition from the mid-Tertiary orogeny to Basin and Range faulting, which did not take place simultaneously throughout southern Arizona (Shafiqullah et al., 1980). In southeastern Arizona the intensity of volcanism peaked about $26 \mathrm{~m} . y . B . P$. as the volcanic arc swept westward during the steepening of the Benioff zone in the late 01 igocene and early Miocene (Coney and Reynolds, 1977). At first the volcanism was calc-alkaline, but as the main magmatic arc passed westward the volcanism became highly potassic with the eruption of potassic trachyandesites and ultra-potassic trachytes (Shafiqullah et a1., 1980). Towards the close of the mid-Tertiary orogeny, volcanism became almost entirely basaltic.

In the Kitt Peak GRA, mid-Tertiary volcanics and sediments crop out in the western Baboquivari Mountains at the center of the GRA, Comobabi Mountains in the northwest, the foothills of the Roskruge Mountains in the 
0

○

0 
northeast and the Black Hills at the eastern edge of the area (see fig. 3 , units Ts, Tvs, Tvi, Til. Additional information is available only for the Coyote Mountains - Baboquivari Mountains area.

Mid-Tertiary rocks of the Coyote Mountains consist of generally N-S trending, near vertical dikes. The dikes are about one meter wide by six to 60 meters long and are composed of augite phenocrysts in a felty groundmass of plagioclase, quartz, chlorite and opaques. Although termed lamprophyres by early workers, these rocks lack the high potassium and/or sodium content characteristic of lamprophyres. One Tertiary dike in the western Coyote Mountains consists of phenocrysts of magnetite in a fibrous chloritic(?) matrix (Gardulski, 1980). Wright and Haxel (1982) report the occurrence of similar dikes in the east-central Baboquivari Mountains; there the "1 amprophyre" dikes are cut by 24 m.y.B.P. rhyolite dikes.

Heindl and Fair (1965) report the occurrence of Tertiary volcanic conglomerate, andesite flows, rhyolite tuffs, welded tuffs and agglomerates in west-central Baboquivari Mountains. Fair (1965) describes the Yellowstone Wash Formation of that same area. The Yellowstone Wash Formation consists mainly of deep red, bedded conglomerate with lesser interbedded andesite flows, some possibly correlative with the 25-30 m.y.B.P. Turkey Track Porphyry of the Tucson area, and sedimentary breccias. This formation probably unconformably overlies late Mesozoic rocks and Laramide(?) conglomerate (Fair, 1965; Haxel and others, 1980). Overlying the Yellowstone Wash Formation are 1250 feet of rhyolite, tuff, welded tuff, tuff breccia, andesite, and clastics of fluvial origin, which Fair (1965) terms the Kohi Kug volcanics.

\section{Late Tertiary}

Late Tertiary deposits occur in all the tectonic basins formed during 
0

○

0 
the Basin and Range disturbance. The depth of these basins have been estimated by Oppenheimer and Sumner (1980) through gravity modeling and drillhole data and is shown in figure 1. The Baboquivari valley, in the western part of the Kitt Peak GRA, and the Altar Valley, in the east, both are greater than 4800 feet deep.

The deposits consist mainly of poorly consolidated, tan colored fanglomerate, sandstone, and siltstone of fluvial and lacustrine origin, and minor basalt (Scarborough and Wilt, 1979; Eberly and Stanley, 1978). These deposits rest unconformably on mid-Tertiary or older rocks.

The initiation of Basin and Range faulting and deposition of basin-fill sediments took place 13-12 m.y.B.P. according to Eberly and Stanley (1978). Shafiqullah and others (1980), however, present evidence to show that the transition from the mid-Tertiary orogeny to the Basin and Range disturbance took place over the time interval between 19 and 12 m.y.B.P., and that the basaltic volcanism decreased in intensity from 9 to 4 m.y.B.P. The interval during which Basin and Range tectonism, volcanic activity and sedimentation was dominant in southwestern Arizona was probably 14 - 4 m.y.B.P. (Shafiqullah et al., 1980), though some basaltic volcanism is as young as 1 $m \cdot y \cdot B \cdot P$.

\section{Latest Tertiary and Quaternary}

During the last four million years volcanic and tectonic activity has slowed down in southwestern Arizona. The dominant geological processes have been erosion of ranges and formation of extensive pediments, deposition of fanglomerates and deposition of alluvium.

\section{Structural Geology}

The GRA lies within the North American craton and east of the Wasatch Line and has been affected by tectonism during mid-Mesozoic, Laramide and 
0

0

• 
mid-Tertiary orogenies and most recently by the Basin and Range disturbance. The area is, therefore, structurally very complex. It is only recently, and largely as a result of detailed structural studies and extensive radiometric dating, that the structure and tectonics of the area has begun to be understood. Particularly important recent studies include strain analysis of various deformations by Davis (1981) and a summary of recent radiometric dates by Shafiqullah and others (1980).

No pronounced tectonic or igneous activity took place during the Paleozoic, but southwestern Arizona was strongly affected by a mid-Mesozoic magmatic arc and a later period of metamorphism and folding. The magmatic arc extended across southwestern Arizona (see fig. 2C) during mid-Jurassic and produced voluminous volcanism and granitic plutonism. The area underwent folding and metamorphism after deposition of molasse-like sediments and prior to the Laramide orogeny. Northwest-trending strike slip faulting was initiated (Davis, 1981) and movement along the Mojave-Sonora left-lateral mega-shear (see fig. 2B) probably took place at this time (silver and Anderson, 1974). Northwest-trending linear discontinuities in depositional patterns (see fig. 2) were produced in southeastern Arizona (Titley, 1976).

The Laramide was a period of intense tectonism and localized magmatic and metamorphic activity which were associated with the southeastward migration of the magmatic arc (Coney and Reynolds, 1977; Lowe11, 1974). The Laramide basement-cored uplifts and thrust faults which strike NNW to NW (Nielsen, 1979; Davis, 1981); the WNW left-lateral strike slip faulting of the Texas zone of Schmitt (1966); and the ENE-striking tensional features (Rehrig and Heidrick, 1976) are all probably related to ENE plate motion and compression. Laramide plutons associated with porphyry copper mineralization have a pronounced NNW to NW trend and a secondary ENE trend (Heidrick and Titley, 1982; see fig. 2C). The former is parallel to the Laramide magmatic 
0

○

0 
arc and basement-cored uplifts, and the latter is parallel to Precambrian fold axes and Laramide tensional features.

The mid-Tertiary orogeny lasted approximately from 34 to 14 m.y.B.P. (Shafiqullah et al., 1980) and involved eruption of large volumes of volcanic rocks, emplacement of metamorphic core complexes and listric normal faulting. These geologic events accompanied the steepening of the Benioff zone and the resultant westward migration of magmatic arc at this time (Coney and Reynolds, 1977 ).

The volcanism produced enormous volumes of ignimbrite eruptions and was dominantly calc-alkaline but became potassic in the later stages. In southwestern New Mexico similar volcanics originated from numerous cauldrons (Elston and Bornhorst, 1979). Cauldrons may be present in southern Arizona, although none have been located to date.

Metamorphic core complexes are characterized by mylonitic augen gneiss and an overlying brittle fracture zone separated by a dislocation surface from an allochthonous upper plate which is unmetamorphosed (Davis and Coney, 1979; Coney, 1980; Rehrig and Reynolds, 1980). The mylonitic foliation defines gently dipping, NE-to-ENE-striking dunes which often have physiographic expression. The mylonitic rocks have pronounced NE-to-ENE lineation which is developed parallel to the direction of extension in the lower plate. Most workers agree that the metamorphic core complexes indeed formed as a response to extension in a NE-SW to ENE-WSW direction. Davis (1980) considers the complexes as mega-boudins, whereas Rehrig and Reynolds (1980) consider that the complexes developed in areas of high heat flow between separating blocks. The relationship of the core complexes to the coeval volcanism is not known. The Coyote Mountains in the northwest corner of the Kitt Peak GRA has mylonitic foliation which is possibly associated with a metamorphic core complex. 
-

○

- 
Listric normal faulting is common in the upper plates of metamorphic core complexes. The faults merge downward into the dislocation surface. The spoon-shaped, gravity-like faults generally strike northwest and typically involve 01igocene and mid-Miocene rocks (Davis, 1981). An example is the northwest part of the GRA; the Mesozoic volcanics and sediments are believed to be listric-faulted upper plate rocks of the Coyote Mountains metamorphic core complex (Wright and Haxel, 1982).

About 14 m.y.B.P. a transition occurred between listric faulting and Basin and Range normal faulting. Basin and Range faults strike NW to N-S and are high angle faults (Davis, 1981). The present-day ranges and basins resulted from this tectonic episode which was terminated in much of southwestern Arizona about 4 m.y.B.P.

\section{Paleontology}

Fossils are important for three major reasons, as follows:

a) Guide fossils which in the sedimentary sequence are most useful for stratigraphic correlation,

b) outstanding fossil specimens or fossils which are extraordinarily well preserved can be beneficial to science and/or tourism, and

c) fossils can be excellent indicators of the paleogeographic and paleoecological environments; as a result, even moderately to poorly preserved "uninteresting" fossils can be geologically important.

Plant fossils must al so be considered important as organic material can trigger the precipitation of uranium and/or other metals.

No fossils are reported from the sedimentary rocks of the Kitt Peak GRA. Gardulski (1980) reports that any fossils originally occurring in the 
○

○

○ 
Paleozoic metasediments of the Coyote Mountains have been destroyed. Other workers in the Baboquivari Mountains have not reported about fossils. Upper Mesozoic sediments of the Sierrita Mountains, just east of the GRA, contain pelecypods, gastropods and fresh water ostracods. Fossils may also occur in unmetamorphosed sediments of the Kitt Peak GRA.

\section{Geologic History}

The geologic history of the area is complex and only a brief synopsis is presented here. Excellent summaries of the main geological events that affected the southern Cordillera of North America are given by Burchfiel (1979) and Dickinson (1981). More detailed accounts pertaining particularly to southern Arizona are given by Titley (1982) and Shafiqullah and others (1980). The geologic history can be summarized as follows:

1. No Precambrian rocks now occur in the GRA and surrounding areas,

2. During the Cambrian the GRA was submerged beneath epicontinental seas. At this time, shallow marine clastic sandstone, mudstone and minor limestone were deposited (Heindl and McClymonds, 1964).

3. No deposition took place during the Ordovician and Silurian, and the Cambrian is disconformably overlain by a Devonian to Early Mississippian transgressive sequence of clastics and carbonates (Teichert, 1955; Bryant, 1968).

4. Late Paleozoic sediments do not occur in the area; possibly they were removed by erosion during the mid-Mesozoic orogeny. Molasse-like sediments were deposited in local basins in the GRA (Heindl, 1965). The upper part of this sequence contains volcanic material, possibly derived from the magmatic arc that 
-

○

• 
extended over the GRA during the mid-Jurassic (see fig. 2B). Much of the Baboquyivari Mountains consists of Jurassic intrusives and later Mesozoic sediments and volcanics.

5. The Laramide was a period of intense tectonic activity characterized by NNW-to-NW-striking basement-cored uplifts and thrust faults (Neilsen, 1979; Davis, 1981); WNW-striking, left-lateral faults of the Texas zone (Schmitt, 1966); ENE-striking tensional features (Rehrig and Heidrick, 1976); and intrusion of small epizonal plutons along NW and ENE trends (Heidrick and Titley, 1982). The magmatic activity proceeded from northwest to southeast as the dip of the Benioff zone flattened in the time interval from 70 to 50 m.y.B.P. (Coney and Reynolds, d1977). Several Laramide intrusives crop out in the GRA and Laramide metamorphic rocks crop out in the northwest, northeast and southern parts of the Kitt Peak GRA.

6. The Laramide was followed by a period of tectonic quiet and erosion.

7. The mid-Tertiary orogeny lasted from about 35 to $14 \mathrm{~m} \cdot \mathrm{y} \cdot \mathrm{B} . \mathrm{P}$. During this time, a great thickness of fluvial and lacustrine sediments interbedded with voluminous felsic to intermediate volcanics were deposited in northwest-striking basins (Eberly and Stanley, 1978; Scarborough and Wilt, 1979). The volcanism was mainly calc-alkaline (Shafiqullah et al., 1980) and was dominated by ignimbrite eruptions, possibly related to cauldrons. Coeval with the volcanism was the emplacement of metamorphic core complexes which occur along a northwest trending zone (Coney, 1980) possibly including the Coyote 
○

-

• 
Mountains in the northern part of the GRA. Associated with the core complexes and aiso present elsewhere in southern Arizona are listric normal faults (Davis, 1981) which offset upper plate rocks. Volcanism and tectonism migrated westward during the mid-Tertiary as the dip of the Benioff zone steepened (Coney and Reynolds, 1977).

8. After the westward passage of the magmatic arc, listric normal faulting gave way to steep, normal Basin and Range faulting which became dominant after 14 m.y.B.P. (Shafiquilah et al., 1980). At this time basalt became the predominant volcanic rock, the present ranges were uplifted, and the basins were filled with fluvial, lacustrine and marine sediments.

9. Since 4 m.y.B.P., volcanism and tectonism have been minor (Shafiquilah et al., 1980), and the dominant geologic processes have been erosion of ranges resulting in the formation of extensive pediments and deposition of fans in the basins and altuvium along major rivers.

\section{ENERGY AND MINERAL RESOURCES}

The following are descriptions of known mineral deposits, prospects, occurrences, mineralized areas, thermal wells and other energy resources (fig. 3) in the Kitt Peak GRA. Information was derived from the following sources: U.S. Geological Survey (1972, updated 1979 and 1981), Keith (1974), Johnson (1972), Peirce and others (1970), Arizona Bureau of Mines (1969), Stipp and others (1967), Fair (1965) and McCrory and O'Haire (1965).

Scarborough and Wilt (1979) and Luning and Brouillard (1982) were consulted for uranium occurrences within the GRA; the Arizona Department of Mineral Resources (1981) Tist of active mines was also consulted; Witcher and others 
○

0

• 
(1982) was consulted for geothermal resources.

\section{Known Mineral Deposits, Mines or Prospects with Recorded Production}

\section{Good Enough Claims (nos. 1 and 2)}

Synonym Names: Zappia Claims; Soto Group; Esperanza Group; Whi tcomb.

Location: $31^{\circ} 38^{\prime} 54^{\prime \prime} \mathrm{N}, 111^{\circ} 21^{\prime} 51^{\prime \prime} \mathrm{W}$

Sec. 31, T20S, R10E.

Commodities: W (major product); $\mathrm{Ag}, \mathrm{Au}, \mathrm{Cu}$ (minor product); $\mathrm{Pb}$ (potential).

Ore Materials: Wolframite series (huebnerite) with minor scheelite. Deposit Description:

Smail, $N 75^{\circ} \mathrm{W}-\mathrm{N} 60^{\circ} \mathrm{W}$ trending, $60-50^{\circ} \mathrm{NE}$

dipping, ore in quartz lenses in irregular fracture zone through granitic formation; exposed for $800 \mathrm{ft}$. along strike, underground workings.

Geology: Mineralization in Cretaceous volcanic breccia associated with Laramide granite, cross-faulting and post-mineral lamprophyre dikes.

Production: Yes, 50 tons of $\mathrm{Au}, \mathrm{Ag}, \mathrm{Cu}, 40,000$ pounds of $\mathrm{WO}_{3}$ concentrate.

References: U.S.G.S., 1972, CRIB Mineral Resources file 12, Record 1623, p. 4234-4237; Keith, 1974.

2. St. Jude Mine

Location:

$32^{\circ} 07^{\prime} 14^{\prime \prime} \mathrm{N}, 111^{\circ} 27^{\prime} 11^{\prime \prime} \mathrm{W}$

Sec. 17, T15S, R9E.

Commodities: $\mathrm{Ag}$, Cu (major products); $\mathrm{Pb}, \mathrm{Au}, \mathrm{Ba}, \mathrm{Mn}$ (minor products); $\mathrm{Ba}, \mathrm{Mn}$ (occurrence).

Ore Materials: Argentite, native silver (main); manganese, barite (minor).

Deposit Description:

Small deposit located in a shear zone, shaft workings.

Geology: Mineralization in Cretaceous sediments and volcanics associated with Cretaceous-Tertiary granitic intrusions. Mineralization in fault zone cutting Cretaceous sediments.

Production: Yes, 300 tons of ore.

References: U.S.G.S., 1979, CRIB Mineral Resources file 12, Record 1138, p. 2957-2959; Keith, 1974.

\section{Columbia Mine Group}

Location:

$32^{\circ} 03^{\prime} 30^{\prime \prime} \mathrm{N}, 111^{\circ} 47^{\prime} 15^{\prime \prime} \mathrm{W}$

Sec. 1, T16S, R5E.

Commodities: $\mathrm{Cu}, \mathrm{Ag}$ (major products); $\mathrm{Au}$ (minor product).

Ore Materials: Copper carbonates, chalcocite.

Deposit Description:

Small,irregular shaped deposit in a vein/shear zone, tunnel workings.

Geology: Mineralization in Cretaceous-Tertiary granitics.

Production: Yes, small amount, $11 \mathrm{oz} \mathrm{Au/T}, 29 \mathrm{oz}$. Ag/T, 19\% Cu, produced in 1907.

References: U.S.G.S., 1979, CRIB Mineral Resources file 12, 
$\bullet$

0 
Record 1155, p. 3006-3008; Keith, 1974.

\section{Buster Lode Prospect}

Location: $\quad 31^{\circ} 39^{\prime} 54^{\prime \prime} \mathrm{N}, 111^{\circ} 23^{\prime} \mathrm{W}$

Sec. 25, T20S, R9E.

Cormodities: W, Au, Ag.

Ore Materials: Wolframite.

Deposit Description:

Small, located in barren quartz plugs.

Geology: Mineralization in Cretaceous-Tertiary granite and sediments, a number of shallow and deep workings on hanging wall of contact show only sparse mineralization; no evidence for good mineralization.

Production: Yes, small amount.

References: U.S.G.S., 1972, CRIB Mineral Resources file 12, Record 1622, p. 4232-4233.

5. Corona Group

Location:

Commodity:

Ore Materials: Pyrite, gold.

Deposit Description:

$32^{\circ} 00^{\prime} 31^{\prime \prime N}, 111^{\circ} 49^{\prime} 23^{\prime \prime} \mathrm{W}$

Sec. 27, TI6S, R5E.

$\mathrm{Au}$.

Smal1, NW-trending, $60^{\circ} \mathrm{SW}$ dipping, vein shaped, underground workings, inclined shaft.

Geology: Mineralization in Mesozoic diorite porphyry and slate.

Production: Yes, small amount.

References: U.S.G.S., 1979, CRIB Mineral Resources file 12, Record 1157, p. 3012-3014; Stipp et al., 1967.

\section{General Electric Mine}

Synonym Names: Grande Lode; Immense Lode; General Electric Mine I,

Location: II III, IV, V, Las Guijas Group.

Sec. 25, T2OS, R9E.

Commodities: W(major product); $\mathrm{Ag}, \mathrm{Au}, \mathrm{Cu}$ (minor); $\mathrm{Fe}, \mathrm{Pb}, \mathrm{Zn}$, Mn, $F$ (occurrence).

Ore Materials: Wolframite with pyrite, chalcopyrite, galena and bornite.

Deposit Description:

Medium, $\mathrm{N} 65-80^{\circ} \mathrm{W}$ trending, $78^{\circ} \mathrm{N}$ dipping, ore occurs sporadically in quartz veins, underground workings.

Geology: Mineralization in volcanic breccia associated with Cretaceous-Tertiary granite, mineralization occurred at contact of granite with breccia, N65 W fault zone.

Production: Yes, small amount, 2000 tons of AuAgCu ore, 155,000 pounds $\mathrm{WO}_{3}$ concentrate.

References: U.S.G.S., 1981 , CRIB Mineral Resources file 12, Record 1621, p. 4229-4231; Keith, 1974.

\section{Vindicator Group}

Synonym Names: Stewart-Fernstrom (Carboloy Group; Union Nos. 1-3; 
$\bullet$

0

• 


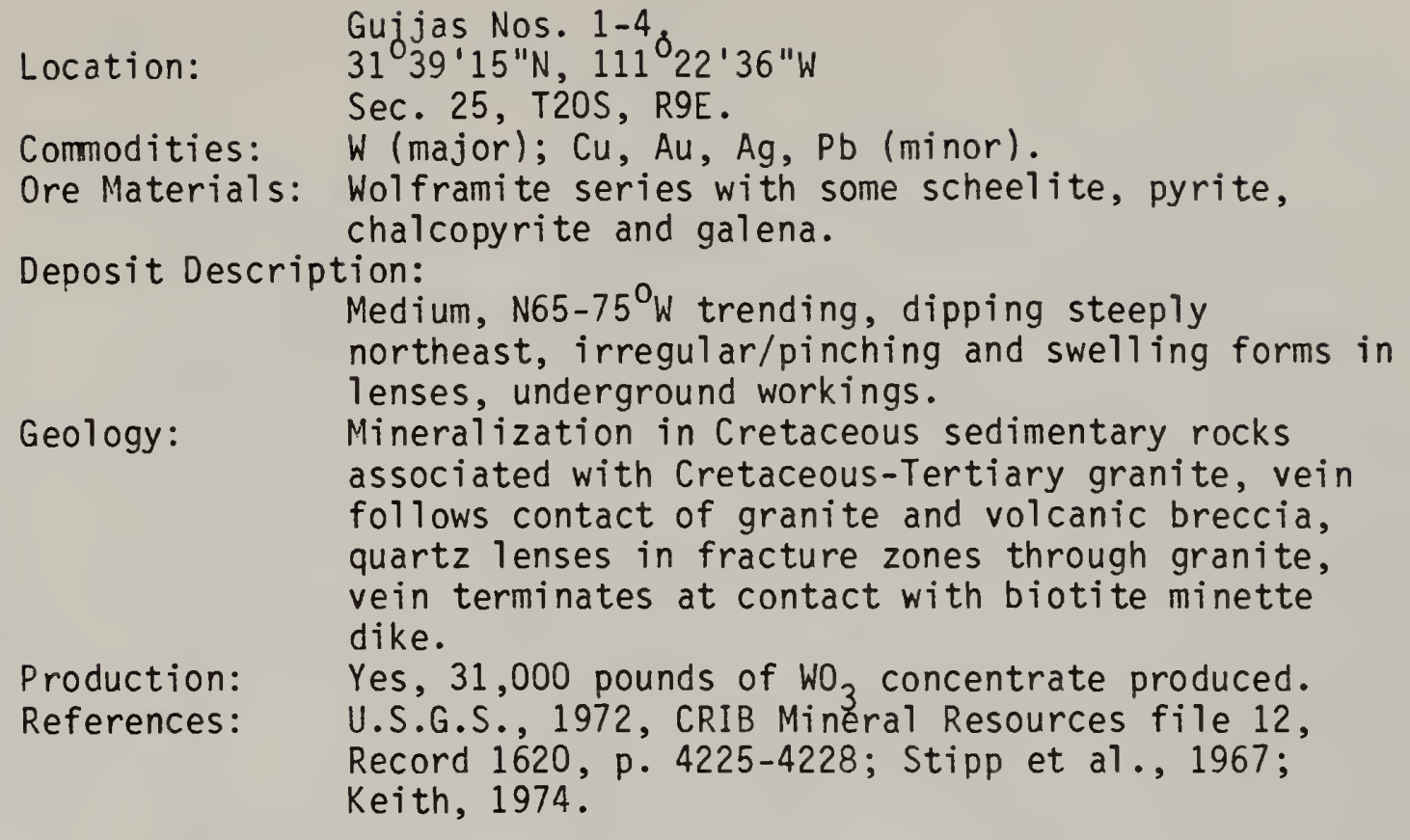

\section{Obregon Claims}

Location:

$31^{\mathrm{O}} 39^{\prime} \mathrm{N}, 111^{\mathrm{O}} 22^{\prime} 12^{\prime \prime} \mathrm{W}$

Sec. 25, 36, T20S, R9E.

Commodity:

W.

Ore Materials: Unknown.

Deposit Description:

Small.

Geology: Unknown.

Production: Yes, small amount.

References: $\quad$ U.S.G.S., 1972, CRIB Mineral Resources file 12 , Record 1619 , p. 4223-4224.

\section{Badger Mine \\ Location:}

$31^{\circ} 59^{\prime} 33^{\prime \prime} \mathrm{N}, 111^{\circ} 49^{\prime} 13^{\prime \prime} \mathrm{W}$

Commodities:

SE $1 / 4 \mathrm{Sec} .34, \mathrm{~T} 16 \mathrm{~S}, \mathrm{R} 5 \mathrm{E}$.

Ore Materials: Auriferous iron oxides.

Deposit Description:

Smal1, $N 70^{\circ} \mathrm{E}$ trending. Irregular sugary quartz-calcite vein with spotty oxidized pyrite, showing enriched gold and silver values in iron oxides near the surface. underground workings consisting of relatively shallow inclined shaft.

Geology:

Production: Mineralization in Cretaceous-Tertiary granitic intrusive. Sericitized and silicified wall rock with oxidation near the surface. References: U.S.G.S., 1979, CRIB Mineral Resources file 12 , Record 1161, p. 3023-3025; Keith, 1974.

\section{Bonanza Mine}

Synonym Name:

Location:

$$
\begin{aligned}
& \text { SRK. } \\
& 32^{\circ}{ }^{\prime} 0^{\prime} 22^{\prime \prime} N, 111^{\circ} 31^{\prime} 09^{\prime \prime} W \\
& \text { W central Sec. } 26, \mathrm{~T} 16 \mathrm{~S}, \mathrm{R} 8 \mathrm{E} .
\end{aligned}
$$




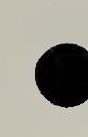

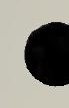

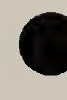


Commodities: $\mathrm{Cu}$ (major product); $\mathrm{Ag}, \mathrm{Au}, \mathrm{Zn}$, Mo (minor products).

Ore Materials: Pyrite, chalcopyrite, bornite, covellite and chalcocite (major); molybdenite and sphalerite

Deposit Description: (minor).

Sma11, pyrometosomatic, high grade deposit, underground shaft and adit operations.

Geology: $\quad$ Mineralization in Paleozoic limestone associated with Cretaceous-Tertiary aplitic to pegmatitic quartz monzonite.

Production: Yes, 700 tons of ore from 1909-1951.

References: U.S.G.S., 1979, CRIB Mineral Resources file 12, Record 1163, p. 3029-3031; Stipp et a1., 1967; Keith, 1974.

12. Calabi Placers

Location:

$31^{0} 58^{\prime} 54^{\prime \prime} \mathrm{N}, 111^{\circ} 48^{\prime} 35^{\prime \prime} \mathrm{W}$

Commodity:

Sec. 3, T17S, R5E.

Ore Materials: Gold.

Deposit Description:

Smal1, placer, surface workings.

Geology: Mineralization in Quaternary gravels.

Production: Yes, small amount.

References: $\quad$ U.S.G.S., 1979, CRIB Mineral Resources file 12 , Record 1170, p. 3051-3052.

13. Lucido Claim Group

Synonym Name: Golden Star.

Location:

$31^{\circ} 59^{\prime} 08^{\prime \prime} \mathrm{N}, 111^{\circ} 49^{\prime} 01^{\prime \prime} \mathrm{W}$

NE $1 / 4$ Sec. 3, T17S, R5E.

Commodities: $\mathrm{Au}, \mathrm{Ag}$ (major products); $\mathrm{Cu}$ (minor product).

Cre Materials: Gold and silver (major); oxidized copper (minor).

Deposit Description:

Small, irregular, lensing shaped deposit in a vein/shear zone, surface and underground workings of inclined shaft and trenches.

Geology: Mineralization in Mesozoic diorite.

Production: $\quad$ Yes, 100 tons of ore averaging $0.4 \mathrm{oz}$. Au/T.

References: U.S.G.S., 1979, CRIB Mineral Resources file 12, Record 1171, p. 3053-3055; Stipp et al., 1967; Keith, 1974.

15. Ventana Mine Group

Location:

$31^{0} 46^{\prime} 51^{\prime \prime} \mathrm{N}, 111^{\circ} 39^{\prime} 44^{\prime \prime} \mathrm{W}$

Sec. 18, TI9S, R7E.

Commodities: $\mathrm{Cu}, \mathrm{Ag}, \mathrm{Au}$ (major products); $\mathrm{Pb}, \mathrm{Zn}, \mathrm{Mn}$ (minor products).

Ore Materials: Base metal sulfides.

Deposit Description:

Small deposit in a vein/shear zone, surface and underground workings.

Geology: Mineralization in Cretaceous volcanics and sediments (metamorphosed) associated with Cretaceous-Tertiary granitic intrusive. 


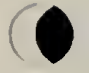

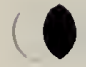

( 
Production: Worked sporadically to 1954 , produced 185 tons of ore averaging about $1.3 \% \mathrm{Cu}, 2 \mathrm{oz} . \mathrm{Ag} / \mathrm{T}$ and $0.7 \mathrm{oz}$. $\mathrm{Au} / \mathrm{T}$.

References: U.S.G.S., 1979, CRIB Mineral Resources file 12 , Record 1250, p. 3286-3288; Keith, 1974.

16. Iowana Mine

Location:

$31^{\circ} 43^{\prime} 57^{\prime \prime N}, 111^{\circ} 35^{\prime} 03^{\prime \prime} \mathrm{W}$

Sec. 36, T19S, R7E.

Cormodities: $\mathrm{Au}, \mathrm{Ag}$ (major products); $\mathrm{Pb}, \mathrm{Cu}$ (minor products); $\mathrm{Zn}$ (potential); W (occurrence).

Ore Materials: Gold and silver (major); base metal sulfides and

Deposit Description: wolframite (minor).

Small, lensing in a vein/shear zone, underground workings consisting of shallow shafts and tunnels.

Geology:

Mineralization in Cretaceous sediments (partly metamorphosed) associated with Cretaceous-Tertiary granite and diorite porphyry dikes.

Production: Yes, 100 tons of ore averaging $1 \mathrm{oz}$. Au/T and $16 \mathrm{oz}$. $\mathrm{Ag} / \mathrm{T}$.

References: U.S.G.S., 1979, CRIB Mineral Resources file 12, Record 1251, p. 3289-3291; Stipp et al., 1967; Keith, 1974.

\section{Jupiter Mine}

Location:

$31^{\circ} 44^{\prime} 05^{\prime \prime N}, 111^{\circ} 35^{\prime} 13^{\prime \prime} \mathrm{W}$

Sec. 36, T19S, R7E.

Cormodities: $\mathrm{Au}, \mathrm{Ag}$ (major products); $\mathrm{Pb}, \mathrm{Cu}$ (minor products); $\mathrm{Zn}$ (potential).

Ore Materials: Auriferous-argentiferous pyrite (major); base metal Deposit Description: sulfides (minor).

Small deposit in a vein/shear zone, shafts and tunnels, and underground workings.

Geology:

Mineralization in Cretaceous metamorphosed sediments associated with Cretaceous-Tertiary granite and diorite dikes.

Production: Yes, produced about 400 tons of ore averging $0.7 \mathrm{oz}$. $\mathrm{Au} / \mathrm{T}, 12 \mathrm{0z} . \mathrm{Ag} / \mathrm{T}$.

References: U.S.G.S., 1979, CRIB Mineral Resources file 12, Record 1252, p. 3292-3294; Stipp et al., 1967; Keith, 1974.

18. Edna J. Placer

Synonym Name:

Location:

Baboquivari Placers

$31^{\circ} 43^{\prime} 33^{\prime \prime} \mathrm{N}, 111^{8} 33^{\prime} 34^{\prime \prime} \mathrm{W}$

Sec. 31, 32, T19S, R8E,

Commodity:

Sec. 5, 6, T2OS, R\&E.

Ore Materials: Gold.

Deposit Description:

Smal1, E-trending, gravel bar placer.

Geology: Mineralization in Quaternary gravel resting on granite pediment. 
$\bullet$

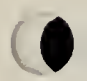

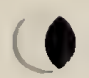


Production: Yes, a few tens of ounces of gold recovered.

References: U.S.G.S., 1972, CRIB Mineral Resources file 12, Record 1253, p. 3295-3297; Keith, 1974; Johnson, 1972.

\section{Arizona Molybdenum Mine}

$\begin{array}{ll}\text { Location: } & 31^{\circ} 43^{\prime} 11^{\prime \prime N}, 111^{\circ} 35^{\prime} 54^{\prime \prime} W \\ & N \text { cen. Sec } 2, T 20 S \text {, R7E. }\end{array}$

Commodities: Mo (major product); $\mathrm{Cu}, \mathrm{Ag}, \mathrm{Au}, \mathrm{Pb}$ (occurrence).

Ore Materials: Base metal sulfides and molybdenite (major); galena

Deposit Description: (minor).

\section{Sma11, NW trending, lensing in pegmatitic}

Geology: veins/dikes, surface and underground workings. Mineralization in Cretaceous-Paleocene granite associated with Cretaceous-Paleocene pegmatitic veins, dikes.

Production: Yes, small amount.

References: U.S.G.S., 1979, CRIB Mineral Resources file 12, Record 1262, p. 3322-3324; Stipp et a1., 1967; Keith, 1974 .

20. Emmett and Elgin Mine

Location: $31^{\circ} 42^{\prime} 47^{\prime \prime} \mathrm{N}, 111^{\circ} 39^{\prime} 19^{\prime \prime} \mathrm{W}$

Sec. $3, \mathrm{~T} 20 \mathrm{~S}, \mathrm{R} 7 \mathrm{E}$.

Commodities: Au (major product); $\mathrm{Ag}, \mathrm{Cu}$ (minor products).

Ore Materials: Auriferous pyrite (major); base metal sulfides (minor).

Deposit Description:

Small, irregular shaped in shear zones, shallow workings.

Geology: Mineralization in Cretaceous sediments (metamorphosed) associated with Cretaceous-Tertiary granitic intrusive.

Production: Yes, 150 tons of ore averaging $1 \mathrm{oz}$. Au/T, minor $\mathrm{Ag}$, $\mathrm{Cu}$.

References: $\quad$ U.S.G.S., 1979, CRIB Mineral Resources file 12, Record 1263, p. 3325-3327; Keith, 1974.

21. Gold King Mine

Location:

$31^{\circ} 42^{\prime} 27^{\prime \prime} \mathrm{N}, 111^{\circ} 36^{\prime} 44^{\prime \prime} \mathrm{W}$

NE $1 / 4 \mathrm{Sec} .10, \mathrm{~T} 20 \mathrm{~S}, \mathrm{R} 7 \mathrm{E}$.

Commodities: $\mathrm{Au}, \mathrm{Ag}$ (major products); $\mathrm{Pb}, \mathrm{Cu}$ (minor products); $\mathrm{Zn}$ (potential); Be, Mn (occurrence).

Ore Materials: Base metal oxides and sulfides.

Deposit Description:

Sma11, in a vein/shear zone, underground workings of shafts, adits and pits.

Geology: Mineralization in Cretaceous metamorphosed sediments associated with Cretaceous-Tertiary granite porphyry dikes.

Production: Yes, 500 tons of ore averaging $1 \mathrm{oz}$. Au/T, $12 \mathrm{oz}$. $\mathrm{Ag} / \mathrm{T}$.

References: U.S.G.S., 1979, CRIB Mineral Resources file 12, Record 1264, p. 3328-3330; Stipp et al., 1967; 


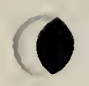

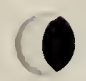

( 


\section{Keith, 1974.}

\section{Papago Chief Mine}

Synonym Name: Napolean.

Location:

$31^{\circ} 40^{\prime} 33^{\prime \prime} \mathrm{N}, 111^{0} 37^{\prime} 42^{\prime \prime} \mathrm{W}$

Sec. 21, T20S, R7E.

Commodities: $\mathrm{Cu}, \mathrm{Ag}$ (major products); $\mathrm{Au}, \mathrm{Pb}$ (minor products); $\mathrm{Zn}$ (potential); U (occurrence).

Ore Materials: Base metal sulfides, metatorbenite.

Deposit Description:

Smal1, E-W trending, veins, underground workings.

Geology:

Mineralization in Cretaceous sediments (partly

metamorphosed) associated with Cretaceous-Tertiary

granite and diorite dikes.

Production: Yes, 4500 tons of ore at $2 \% \mathrm{Cu}, 5.6 \mathrm{oz}$. Ag/T, 0.04 Oz. Au/T.

References: U.S.G.S., 1981, CRIB Mineral Resources file 12 , Record 1265, p. 3331-3333; Keith, 1974.

\section{Berkley Mine}

Location:

$31^{\circ} 40^{\prime} 40^{\prime \prime N}, 111^{\circ} 37^{\prime} 34^{\prime \prime} \mathrm{W}$

Sec. 21, T20S, R7E.

Commodities: $\mathrm{Cu}, \mathrm{Ag}$ (major products); $\mathrm{Au}$ (minor products); $\mathrm{Pb}, \mathrm{Zn}$ (potential).

Ore Materials: Pyrite, base metal sulfides.

Deposit Description:

Small, in a shear zone/vein, shallow workings, type unknown.

Geology:

Mineralization in Cretaceous sediments (partly metamorphosed) associated with Cretaceous-Tertiary dikes.

Production: Yes, 1936-1937 200 tons of ore averaging $2.5 \% \mathrm{Cu}$, $0.04 \mathrm{Oz} \mathrm{Au/T}$ and $6.5 \mathrm{oz}$. Ag/T shipped.

References: U.S.G.S., 1979, CRIB Mineral Resources file 12 , Record 1266, p. 3334-3336; Keith, 1974.

25. Las Guijas Tungsten Placers
Location:
$31^{8} 39^{\prime} 48^{\prime \prime} \mathrm{N}, 111^{\circ} 22^{\prime} 09^{\prime \prime} \mathrm{W}$
Sec. $12,23,24,25$, T2ON, R9E.

Commodity:

W.

Ore Materials: Wolframite and scheelite.

Deposit Description:

Smal1, placers, surface workings. Dry and wet placer operations.

Geology: Mineralization in Quaternary stream gravels, alluvium associated with Cretaceous-Tertiary quartz veins.

Production: Yes, few tons of wolframite concentrates produced during WWI.

References: $\quad$ U.S.G.S., 1979, CRIB Mineral Resources file 12 , Record 1268, p. 3340-3342; Keith, 1974.

26. Liberty Mine

Location:

$31^{\circ} 41^{\prime} 38^{\prime \prime} \mathrm{N}, 111^{\circ} 19^{\prime} 09^{\prime \prime} \mathrm{W}$

NE $1 / 4 \mathrm{Sec} .16$, T2OS, R10E. 

Commodities: $\mathrm{Ag}$ (major product); $\mathrm{Au}, \mathrm{Pb}, \mathrm{Cu}$ (minor products). Ore Materials: Argentiferous galena.

Deposit Description:

Small, oxidized,irregular and spotty in a vein/shear zone, surface and underground workings.

Geology: Mineralization in Cretaceous andesite.

Production: Yes, late $1800^{\prime}$ s and early 1900's, 100 tons of ore.

References: U.S.G.S., 1979, CRIB Mineral Resources file 12 , Record 1270, p. 3346-3348; Keith, 1974.

\section{Silver Hill Mine}

Synonym Name: Gold Coin.

Location:

$31^{\circ} 41^{\prime} 15^{\prime \prime} \mathrm{N}, 111^{\circ} 20^{\prime} 05^{\prime \prime} \mathrm{W}$

E cen. Sec. 17, T20S, R10E.

Commodities: $\mathrm{Ag}$ (major product); $\mathrm{Pb}, \mathrm{Cu}, \mathrm{Au}, \mathrm{Zn}, \mathrm{Hg}$ (minor products).

Ore Materials: Argentiferous base metal sulfides (major);

Deposit Description:

tetrahedrite, cinnabar.

Smal1, oxidized, irregular lensing in a vein/shear zone, underground workings.

Geology: Mineralization in Cretaceous-Tertiary diorite associated with Cretaceous-Tertiary diorite and andesite porphyry.

Production: Yes, sporadic operation from 1800 's to 1930 's, producing some 50 tons of ore.

References: U.S.G.S., 1979, CRIB Mineral Resources file 12, Record 1271, p. 3349-3351; Keith, 1974.

28. New Colorado Mine

Location:

$31^{\circ} 41^{\prime} 21^{\prime \prime} \mathrm{N}, 111^{\circ} 20^{\prime} 16^{\prime \prime} \mathrm{W}$

Sec. 17, T2OS, R10E.

Commodities: $\mathrm{Ag}, \mathrm{Au}, \mathrm{Pb}, \mathrm{Cu}$ (major products); $\mathrm{Zn}$ (minor product); $\mathrm{Hg}$ (occurrence).

Ore Materials: Argentiferous galena, freibergite, copper carbonates

Deposit Description: and oxides, sphalerite (major); cinnabar (minor).

Smal1, partly oxidized, shaped irregularly in a vein/shear zone, surface and underground workings.

Geology: Mineralization in Cretaceous andesite porphyry.

Production: Yes, small amount.

References: U.S.G.S., 1979, CRIB Mineral Resources file 12, Record 1272, p. 3352-3354.

29. Mary G. Mine

Synonym Name: Location:

Mary E. Princess Group $31^{\circ} 40^{\prime} 27^{\prime \prime} \mathrm{N}, 111^{\mathrm{O}} 18^{\prime} 54^{\prime \prime}$

Sec. 21, T2OS, R10E.

Commodities: $\mathrm{Ag}$ (major product); $\mathrm{Pb}, \mathrm{Cu}$ (minor products); $\mathrm{Au}, \mathrm{Zn}$, $\mathrm{Hg}$ (ocurrence).

Ore Materials: Silver, galena, sphalerite, malachite, mercury, Deposit Description: tetrahedrite, cinnabar, anglesite.

Smal1, $N 10^{\circ}$ E trending $45^{\circ} \mathrm{W}$ dipping, irregular, lensing form in a vein, underground 


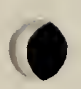

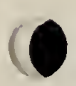

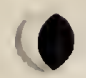




$\begin{array}{ll} & \text { workings. } \\ \text { Geology: } & \text { Mineralization in Cretaceous andesite porphyry. } \\ \text { Production: } & \text { Yes, } 800 \text { tons of ore produced. } \\ \text { References: } & \text { U.S.G.S., 1981, CRIB Mineral Resources file 12, } \\ & \text { Record 1273, p. 3355-3357; Keith, 1974. }\end{array}$

\section{Lesjimfre Claims}

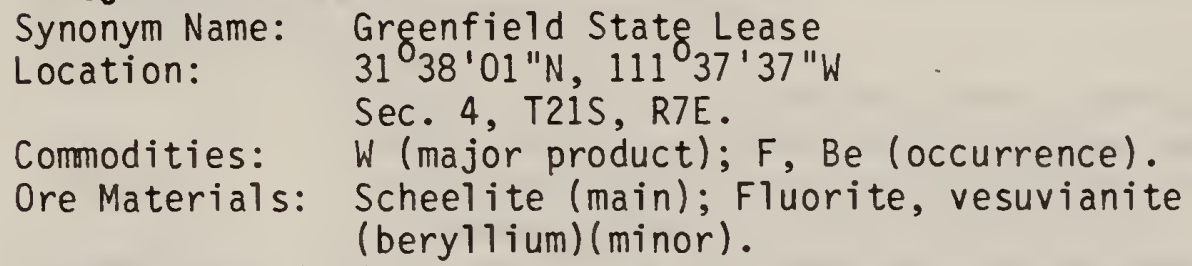

Smail, E-W trending $60^{\circ} \mathrm{N}$ dipping, sporadic in shear zones. Surface and underground workings. Geology: Mineralization in Cretaceous quartzite schistic structure associated with Cretaceous-Tertiary pegmatite dike, porphyritic granite and phonolite porphyry.

Production: Yes, 2 tons of tungsten concentrate produced. References: U.S.G.S., 1979, CRIB Mineral Resources file 12, Record 1275, p. 3361-3363; Keith, 1974.

\section{More Mine}

Location:

Commodities: $\mathrm{Cu}$ (major product); $\mathrm{Au}, \mathrm{Ag}$ (minor product).

Ore Materials: Oxidized copper.

Deposit Description:

Sma11, located in a shear zone, surface workings consisting of open pit and leaching operations.

Geology: Mineralization in Cretaceous sediments associated

with Cretaceous-Tertiary granitic intrusive.

Production: Yes, 1967 produced 100 tons of ore averaging $2 \% \mathrm{Cu}$, $4 \mathrm{oz}$. Ag/T, trace Au.

References: U.S.G.S., 1979, CRIB Mineral Resources file 12, Record 1276, p. 3364-3366; Keith, 1974.

\section{Albatros Mine}

Synonym Names: Gnome King; Albatross Gold Mines.

Location:

$31^{\circ} 37^{\prime} 06^{\prime \prime} \mathrm{N}, 111^{\prime} 22^{\prime} 12^{\prime \prime} \mathrm{W}$

NE $1 / 4 \mathrm{Sec} .12$, T21S, R9E.

Commodities: $\mathrm{Au}, \mathrm{Ag}$ (major products); $\mathrm{Cu}, \mathrm{Pb}$ (minor products); $\mathrm{Zn}$ (potential).

Ore Materials: Argentiferous-auriferous galena (major); sphalerite Deposit Description: and chalcopyrite (minor).

Small, oxidation, enrichment near the surface, irregular lenses in a vein/shear zone, underground workings.

Geology: Mineralization in quartz filled fissure veins cutting Cretaceous-Paleocene granite.

Production: Yes.

References: U.S.G.S., 1981, CRIB Mineral Resources file 12, Record 1278, p. 3370-3372; Stipp et al., 1967; 
$\bullet$

• 
Keith, 1974.

\section{Buena Vista Mine Group}

Synonym Names: Golden Star, Gold Rim, Rebecca.

Location:

$31^{\circ} 36^{\prime} 50^{\prime \prime} \mathrm{N}, 111^{\circ} 19^{\prime} 37^{\prime \prime} \mathrm{W}$

Sec. 4, 9, 16, T21S, R1OE.

Commodities: $\mathrm{Ag}, \mathrm{Au}$ (major products); $\mathrm{Cu}, \mathrm{Pb}$ (minor products).

Ore Materials: Base metal sulfides.

Deposit Description:

Small, numerous, weathered veins, irregular and spotty in a vein/shear zone, shallow workings.

Geology: Mineralization in Cretaceous-Tertiary granitic intrusive, fissure zone in granitics.

Production: Yes, in 1930 's produced 400 tons of ore.

References: U.S.G.S., 1979, CRIB Mineral Resources file 12, Record 1281, p. 3379-3381; Keith, 1974.

34. Arivaca King Mine

Synonym Name: Chapman.

Location:

$31^{\circ} 37^{\prime} 31^{\prime \prime N}, 111^{\circ} 20^{\prime} 09^{\prime \prime} \mathrm{W}$

Sec. 5, T21S, R10E.

Commodities: $\mathrm{Au}, \mathrm{Ag}$ (major product); $\mathrm{Pb}, \mathrm{Cu}$ (minor product).

Ore Materials: Base metal sulfides.

Deposit Description:

Small, irregular, in a vein/shear zone, relatively shall ow workings.

Geology: $\quad$ Mineralization in Cretaceous-Tertiary granitic intrusive.

Production: Yes, small amount.

References: U.S.G.S., 1979, CRIB Mineral Resources file 12,

Record 1282, p. 3382-3384; Stipp et al., 1967.

35. Backbone Mine

Location:

$31^{\circ} 36^{\prime} 52^{\prime \prime} \mathrm{N}, 111^{\circ} 20^{\prime} 28^{\prime \prime} \mathrm{W}$.

Commodities: $\mathrm{Au}, \mathrm{Ag}$ (major products); $\mathrm{Pb}, \mathrm{Cu}$ (minor products); $\mathrm{Zn}$ (potential).

Ore Materials: Auriferous-argentiferous galena (major); sphalerite

Deposit Description: and chalcopyrite (minor).

Small, near surface enrichment, irregular lenses in a vein/shear zone, shaft workings.

Geology: Mineralization in Cretaceous-Tertiary granitics.

Production: yes, 1930's and 1940's 140 tons of ore produced.

References: U.S.G.S., 1979, CRIB Mineral Resources file 12, Record 1283, p. 3385-3387; Keith, 1974.

36. Mamoth Group

Location:

Commodities:

$31^{\circ} 36^{\prime} 32^{\prime \prime} \mathrm{N}, 111^{\circ} 21^{\prime} 33^{\prime \prime} \mathrm{W}$

Sec. 7, T21S, R10E.

Ore Materials:

Deposit Description:

Small, vein, surface workings.

Geology:

Mineralization in Jurassic granite.

Production: Yes, small amount. 
References: U.S.G.S., 1981, CRIB Mineral Resources file 12 , Record 1290, p. 3405-3407; Stipp et al., 1967.

37. Elzo \#4 Mine Location:

$31^{0} 36^{\prime} 58^{\prime \prime} \mathrm{N}, 111^{\circ} 20^{\prime} 30^{\prime \prime} \mathrm{W}$

Sec. 8, T21S, RIOE.

Commodities: $\mathrm{Au}$ (major product); $\mathrm{Ag}$ (minor product); $\mathrm{Pb}$ (occurrence).

Ore Materials: Unknown.

Deposit Description:

Smal1, vein, surface workings.

Geology: Mineralization in Jurassic granite.

Production: Yes, small amount.

References: $\quad$ U.S.G.S., 1981, CRIB Mineral Resources file 12 , Record 1291, p. 3408-3410.

38. Golden Star Mine

Location:

$31^{\circ} 35^{\prime} \mathrm{N}, 111^{\circ} 20^{\prime} \mathrm{W}$

Sec. 9, T21S, RIOE.

Commodities: $\mathrm{Au}, \mathrm{Ag}$ (major products); $\mathrm{Cu}$ (minor product).

Ore Materials: Unknown.

Deposit Description:

Sma11, vein, surface workings.

Geology:

Production:

Mineralization in Jurassic (?) granite.

References:

Yes, small amount.

U.S.G.S., 1981, CRIB Mineral Resources file 12 ,

Record 1292, p. 3411-3413.

39. Jean E. Group

Synonym Name:

Location:

Black Bear Nos. 1 and 2 .

$32^{\circ} 01^{\prime} 44^{\prime \prime} \mathrm{N}, 111^{\circ} 35^{\prime} 50^{\prime \prime} \mathrm{W}$

Sec. 13, T16S, R7E.

Commodities: $M n$ (major product); Cu, $\mathrm{Zn}$, Fe (occurrences).

Ore Materials: Manganese oxides; wad manganese.

Deposit Description:

Smal1, $\mathrm{N} 50-60^{\circ} \mathrm{W}$ trending, steeply northeast

dipping, numerous fractures in zone contain narrow, discontinuous, high-grade veinlets of hard manganese oxides with occasional replacements of softer wad manganese in shattered areas between fractures, surface and underground workings.

Geology: Mineralization in Mesozoic rhyolite porphyry.

Production: Yes, 100 tons of ore, 1954-1955.

References: $\quad$ U.S.G.S., 1972, CRIB Mineral Resources file 12 ,

Record 1515, p. 3909-3912; Keith, 1974.

\section{Black Hawk Group (nos. 1, 2 and 3)}

Synonym Names: Black Eagle nos, 1 and 2; Blue Devil nos. 1 and 2. Location: $32^{\circ} 01^{\prime} 48^{\prime \prime} \mathrm{N}, 111^{\circ} 36^{\prime} 11^{\prime \prime} \mathrm{W}$

Commodity: Sec. 14, T16S, R7E.

Ore Materials: Manganese oxides; soft wad manganese. Deposit Description:

Smail, $N 50-60^{\circ} \mathrm{W}$ trending, vertical to steep NE dipping, irregular veinlets in fracture zone. There 


$\begin{array}{ll}\text { Geology: } & \text { Morkings. } \\ & \text { Mineralization in Mesozoic rhyolite porphyry, } \\ & \text { covered by alluvium. } \\ \text { Production: } & 46 \text { tons of sorted } 20 \% \text { Mn ore shipped in } 1955, \\ \text { References: } & \text { U.S.G.S. 1972, CRIB Mineral Resources file i2, } \\ & \text { Record 3913, p. 3913-3915; Stipp et al., 1967; } \\ & \text { Keith, 1974. }\end{array}$

41. Jaeger Group Mine

Synonym Name: $31^{\circ} 59^{\prime} 05^{\prime \prime} \mathrm{N}, 111^{\circ} 48^{\prime} 47^{\prime \prime} \mathrm{W}$

Commodities: Au (major product); $\mathrm{Ag}$ (minor product); Cu.

Ore Materials: Gold in quartz-carbonate veins, minor pyrite, chalcopyrite.

Deposit Description:

are two parallel fracture zones 300 feet apart containing discontinuous, narrow stringers of hard manganese oxides in most fracture planes, which show gradual replacement outward from the walls and incomplete replacement of softer wad manganese in shattered areas between fractures. Surface workings. fracture zone probably extends to east where it is covered by alluvium.
Small, eastward trending, vertical dip, several narrow quartz veins form the lode, underground workings.
Geology: Mineralization in Jurassic diorite associated with Jurassic diorite to basic dikes.
Production: Yes, 2800 tons of ore from 1930-1943.
References: $\quad$ U.S.G.S., 1981, CRIB Mineral Resources file 12, Record 1521, p. 3926-3928; Stipp et al., 1967; Keith, 1974.

42. Lone Eagle Mine

Location:

$31^{\circ} 58^{\prime} 06^{\prime \prime} \mathrm{N}, 111^{\circ} 41^{\prime} 45^{\prime \prime} \mathrm{W}$

Commodity:

Sec. 1, T17S, R6E.

Ore Materials: Unknown.

Deposit Description:

Smal1, $\mathrm{N} 10^{\circ} \mathrm{E}$ trending, $60^{\circ} \mathrm{E}$ dipping, ore is in gouge in bedding plane fault, in a shear zone, surface workings.

Geology:

Mineralization in Mesozoic quartzite. There is granular gougy material between the hanging wall of

Production: $\quad$ quartzite and metamorl amount.

References: U.S.G.S., 1972, CRIB Mineral Resources file 12, Record 1522, p. 3929-3931.

44. Southside Mine

Location:

$31^{\circ} 56^{\prime} 42^{\prime \prime} \mathrm{N}, 111^{\circ} 41^{\prime} 17^{\prime \prime} \mathrm{W}$

Commodity: Sec. 13, T17S, R6E.

Ore Materials: Scheelite.

Deposit Description:

Smal1, N65 ${ }^{\circ}$ E trending, $55^{\circ} \mathrm{SE}$ dipping, 
-

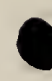
0 
located in a shear zone, surface workings.

Geology: Mineralization in Mesozoig quartzite, quartzite strikes $\mathrm{N} 80^{\circ} \mathrm{W}$ and dips $70^{\circ} \mathrm{N}$.

Production: Yes, small amount.

References: U.S.G.S., 1972, CRIB Mineral Resources file 12, Record 1524, p. 3935-3937.

\section{Calvert Prospects}

Synonym Name: Nelson's Pride Mine.

Location:

Commodity:

$31^{\circ} 57^{\prime} 04^{\prime \prime} \mathrm{N}, 111^{\circ} 41^{\prime} 25^{\prime \prime} \mathrm{W}$.

Ore Materials: Scheelite.

Deposit Description:

Small, $57^{\circ} \mathrm{E}$ trending, $80^{\circ} \mathrm{N}$ dipping, located

in a shear zone, surface and underground workings

consisting of pits, one shaft and one

diamond-drilled hole.

Geology: Mineralization in Mesozoic quartzite, epidote and manganese occur on fracture planes, rock is dense and compact leaving little room for tungsten mineralization.

Production: Yes, small amount.

References: U.S.G.S., 1972, CRIB Mineral Resources file 12, Record 1525, p. 3938-3940; Stipp et al., 1967.

48. Independence Group

Synonym Name: Independence no.1 and 2; New Dragon no. 4.

Location:

$31^{\circ} 56^{\prime} \mathrm{N}, 111^{\circ} 41^{\prime} 11^{\prime \prime} \mathrm{W}$

Sec. 24, T17S, R6E.

Commodities: W (main product); $\mathrm{Au}, \mathrm{Ag}, \mathrm{Cu}$ (occurrences).

Ore Materials: Scheelite, chrysocolla, malachite and limonite.

Deposit Description:

Small, $\mathrm{N} 10^{\circ} \mathrm{W}$ trending, $70^{\circ} \mathrm{E}$ dipping, narrow deposit in shear zone, surface and underground workings.

Geology: $\quad$ Rock is altered and friable and contains coatings of copper oxides.

Production: Yes, small amount.

References: U.S.G.S., 1972, CRIB Mineral Resources file 12, Record 1528, p. 3946-3948.

\section{Rushbeg Prospect}

Synonym Name:

Location:

Birthday Claim.

$31^{\circ} 56^{\prime} 12^{\prime \prime} \mathrm{N}, 111^{\circ} 40^{\prime} 49^{\prime \prime} \mathrm{W}$

Sec. 19, T17S, R7E.

Commodity:

W.

Ore Materials: Scheelite.

Deposit Description:

Smail, $\mathrm{N}^{\circ} 0^{\circ} \mathrm{W}$ trending, $30^{\circ} \mathrm{W}$ dipping, surface workings.

Geology: Mineralization in Mesozoic quartzite, scheelite-bearing band of hydrothermally al tered material, band is overlain by massive quartzite and overlain by sheared and shattered quartzite.

Production: Yes, small amount. 
•

0

0 
References: U.S.G.S., 1972, CRIB Mineral Resources file 12, Record 1529, p. 3949-3951.

50. Yellow Star Mine

Synonym Name: Yellow Dragon no. 1 and 2; New Dragon nos. 1 and 2 Claims.

Location: $\quad 31^{8} 55^{\prime} 47^{\prime \prime} \mathrm{N}, 111^{\circ} 41^{\prime} 01^{\prime \prime W}$.

Sec. 19, T17S, R7E,

Commodity:

Sec. 24, T17S, R6E.

Ore Materials: Scheelite.

Deposit Description:

Small, SE trending, dip varies, one ore body became

flat lying at the 60 foot depth; on opposite side of the ridge from this main ore body, another zone of mineralization was mined which consisted of nearly vertical southeast trending shears containing numerous narrow stringers in a mineralized fault, surface and underground workings.

Geology: Mineralization in Cretaceous quartzite.

Production: Yes, 700 tons of tungsten ore.

References: U.S.G.S., 1972, CRIB Mineral Resources file 12, Record 1530, p. 3952-3954; Keith, 1974.

51. Jezebel Mine

Location:

$31^{\circ} 55^{\prime} 35^{\prime \prime N}, 111^{\circ} 40^{\prime} 32^{\prime \prime} \mathrm{W}$

Commodity:

Sec. 19, TI7S, R7E.

Ore Materials: Unknown.

Deposit Description:

Smail, 10 to $15^{\circ} \mathrm{SE}$ dip, lens form in a shear zone, the greatest concentration of scheelite was in the bottom 12 to 18 inches of mineralized zone, where alteration has been greatest and the siliceous material is vuggy and granular.

Geology: Mineralization in Cretaceous quartzite.

Production: Yes, about 600 tons of tungsten ore produced in mid-1950's.

References: U.S.G.S., 1972, CRIB Mineral Resources file 12, Record 1531, p. 3955-3957; Keith, 1974.

\section{Sparks Mine}

Synonym Name:

Location:

Commodity:

Ore Materials: Scheelite.

Deposit Description:

Juanita no. 9.

$31^{0} 54^{\prime} 47^{\prime \prime} \mathrm{N}, 111^{\circ} 40^{\prime} 14^{\prime \prime} \mathrm{W}$

Sec. $29,30,31$, T17S, R7E.

W.

Smail, $520^{\circ} \mathrm{W}$ trending, $70^{\circ} \mathrm{SE}$ dipping, lens

shaped in a shear zone, there is scheelite

mineralization in fracture zone, surface and underground workings.

Geology: Mineralization in Cretaceous hornfels.

Production: Yes.

References: U.S.G.S., 1972, CRIB Mineral Resources file 12, 


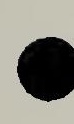

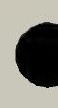

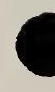


Record 1532, p. 3958-3960; Keith, 1974.

54. Brown Prospect

Synonym Name:

Location:

Commodity:

Ore Materials:

Deposit Description:

Big Juanita Group:

$31^{\circ} 54^{\prime} 52^{\prime \prime} \mathrm{N}, 111^{\circ} 40^{\prime} 01^{\prime \prime} \mathrm{W}$

Sec. 29, 30, T17S, R7E.

W.

Scheelite.

Sma11, NW dipping, deposit in a shear zone, surface workings.

Geology:

Production:

References:

Mineralization in Cretaceous quartzite cut by aplite dikes.

Yes, 50 pounds of $62 \%$ tungsten.

U.S.G.S., 1972, CRIB Mineral Resources file 12, Record 1534, p. 3963-3965; Stipp et a1., 1967;

Keith, 1974.

55. Last Chance Mine

Location:

$31^{\circ} 54^{\prime} 57^{\prime \prime} \mathrm{N}, 111^{\circ} 40^{\prime} 33^{\prime \prime} \mathrm{W}$

Sec. 30, T17S, R7E.

Commodity:

W.

Ore Materials: Scheelite.

Deposit Description:

Small, east-west trending, vertical to east dipping, surface and underground workings.

Geology:

Mineralization in Cretaceous quartzite, ore in metamorphosed band appears originally to have been limestone interbedded with sandstone layers.

Production: Yes, small amount.

References: U.S.G.S., 1972, CRIB Mineral Resources file 12, Record 1535, p. 3966-3968.

56. San Juan Mine

Location:

$31^{\circ} 55^{\prime} 06^{\prime \prime} \mathrm{N}, 111^{\circ} 40^{\prime} 13^{\prime \prime} \mathrm{W}$

Commodity:

Sec. 30, T17S, R7E.

Ore Materials:

W.

Deposit Description:

Smail, NE trending, $45^{\circ}$ SE dipping,

lens/discontinuous band shape in a shear zone, surface and underground workings.

Geology: Mineralization in Cretaceous quartzite, mineralization mostly confined to one band.

Production: Yes, 8000 pounds of tungsten concentrate produced in 1954 and 1957.

References: $\quad$ U.S.G.S., 1972, CRIB Mineral Resources file 12, Record 1536, p. 3969-3971; Keith, 1974.

\section{Big Banana Mine}

Synonym Name:

Location: Big Banana nos. $1,2,3$ Claims; Maud E. Claim.

Sec. 32, T17S, R7E.

Commodities: W (major); Cu, Mo, F (occurrence).

Ore Materials: Molybdenum-bearing scheelite. 
-

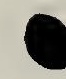

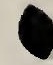


Deposit Description:

Small, N10-20 $\mathrm{W}$ trending, eastern dip, surface and underground workings.

Geology: Mineralization in Cretaceous quartzite associated with Cretaceous-Tertiary(?) metamorphosed rhyolite, tensional shears in major northwest striking fault zone.

Production: Yes, 20,000 pounds of tungsten concentrates produced.

References: $\quad$ U.S.G.S., 1972, CRIB Mineral Resources file 12, Record 1537, p. 3972-3974.

58. Black Dragon Group

$\begin{array}{ll}\text { Location: } & 31^{0} 51^{\prime} 23^{\prime \prime} \mathrm{N}, 111^{\circ} 35^{\prime} 58^{\prime \prime} \mathrm{W} \\ & \mathrm{Sec} .15,22, \mathrm{~T} 18 \mathrm{~S}, \mathrm{R} 7 \mathrm{E} .\end{array}$

Comodity: $\mathrm{Mn}$.

Ore Materials: Manganese oxides, pyrolusite.

Deposit Description:

Small, north-south trending, irregular fracture fillings in a vein/shear zone, discontinuous manganese mnerals are present in fracture zone, surface workings.

Geology: Mineralization in Mesozoic rhyolite associated with Tertiary rhyolite.

Production: Yes, 65 long tons of sorted $\mathrm{Mn}$ ore and 19 tons of $\mathrm{Mn}$ concentrate.

References: $\quad$ U.S.G.S., 1972, CRIB Mineral Resources file 12, Record 1555, p. 4015-4018; Keith, 1974.

59. Allison Mine

Synonym Name: Chance; El Oro; 01d Gold.

Location:

$31^{\circ} 49^{\prime} 01^{\prime \prime} \mathrm{N}, 111^{\circ} 37^{\prime} 58^{\prime \prime} \mathrm{N}$.

Commodities: $\mathrm{Au}$ (major product); $\mathrm{Ag}$, quartz, $\mathrm{Cu}, \mathrm{Pb}$ (minor products); Mn (occurrence).

Ore Materials: Native gold, argentite (main); silver-gold chlorides

Deposit Description: (minor).

Small, eastward trending, $50^{\circ} \mathrm{SW}$ dipping, located in a vein/shear zone, underground workings.

Geology: Mineralization in Miocene conglomerate associated with Tertiary andesites and rhyolites. Portions of vein containing abundant manganese and iron oxides have the richest ore.

Production: Yes, total recorded production 47,000 tons of ore, averaging $0.22 \mathrm{oz}$. $\mathrm{Au} / \mathrm{T}, 2.7 \mathrm{oz}$. $\mathrm{Ag} / \mathrm{T}$, minor $\mathrm{Cu}, \mathrm{Pb}$. Worked for silica in early $1960^{\prime} s$ (flux).

References: U.S.G.S., 1981, CRIB Mineral Resources file 12, Record 1556, p. 4018-4021; Stipp et al., 1967; Keith, 1974; Fair, 1965.

60. Giant Claims Synonym Names: Location:

Giant nos. 3-10; Grand Mountain Claim.

$31^{\circ} 39^{\prime} 36^{\prime \prime} \mathrm{N}, 111^{\circ} 40^{\prime} 28^{\prime \prime} \mathrm{W}$

Sec. 24, 25, T20S, R6E,

Sec. 19, 30, T20S, R7E. 
2

0

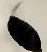


Commodities: Mo, W (minor products); $\mathrm{Cu}, \mathrm{Ag}$ (occurrence).

Ore Materials: Molybdenum-bearing scheelite.

Deposit Description:

Smal1, northerly trending, east to west dipping, irregular shape in a lens, surface workings.

Geology: Mineralization in Cretaceous quartzite associated with aplite dikes, scheelite is in discontinuous lenses in quartzite beds that have probably been faulted with considerable horizontal displacement of various segments.

Production: Yes, 20 tons of low-grade copper-silver ore, 50 tons of tungsten ore produced in 1957.

References: U.S.G.S., 1972, CRIB Mineral Resources file 12 , Record 1613, p. 4205-4207; Keith, 1974.

\section{Gold Bullion Mine}

Synonym Name: Banes 1 and Banes 2 Claims; Last Chance; Tellurium Claim Group.

Location: $\quad 31^{8} 43^{\prime} 24^{\prime \prime} \mathrm{N}, 111^{\circ} 35^{\prime} 47^{\prime \prime} \mathrm{W}$

Sec. 2, T2OS, R7E

Sec. 35, T19S, R7E.

Commodities: $\mathrm{Au}, \mathrm{Mo}$ (major products); $\mathrm{Ag}, \mathrm{Cu}, \mathrm{Pb}$ (minor products); Zn (occurrence).

Ore Materials: Auriferous pyrite (major); chalcopyrite, galena, Deposit Description: sphalerite, and molybdenite (minor).

Smail, $N 70^{\circ} \mathrm{W}$ trending, $70-40^{\circ} \mathrm{N}$ dipping, deposit is quartz veins ranging in size and trend, the deposit pinches and swells in a vein/shear zone, underground workings.

Geology: Mineralization in Cretaceous sediments, cut by aplite granite.

Production: Yes, 3100 tons produced.

References: U.S.G.S., 1972, CRIB Mineral Resources file 12, Record 1614, p. 4208-4211; Stipp et al., 1967 ;

Arizona Bureau of Mines, 1969; Keith, 1974.

\section{Baboquivari Mine}

Synonymn Name: Black Diamond; Red and Black Chief.

Location:

$31^{\circ} 42^{\prime} 27^{\prime \prime} \mathrm{N}, 111^{0} 36^{\prime} 06^{\prime \prime} \mathrm{W}$

Sec. 11, T2OS, R7E.

Comodities: $\quad M n$ (major product); $\mathrm{Fe}, \mathrm{Cu}, \mathrm{Ag}, \mathrm{Au}$ (occurrence).

Ore Materials: Pyrolusite, psilomelane, some rhodonite.

Deposit Description:

Smal1, east-west trending, north to vertical

dipping, iregular and discontinuous veinlets from a

fraction of an inch to a foot or more wide in sporadic areas 1,500 feet or more along strike of fracture zone.

Geology: Mineralization in shattered andesite dike cutting

Production: Yes, small amount.

References: U.S.G.S., 1972, CRIB Mineral Resources file 12, Record 1616, p. 4215-4217; Stipp et a1., 1967 ; Keith, 1974 . 
•

$\bullet$ 
65. Black Gold Mine

Location:

$31^{\circ} 41^{\prime} 42^{\prime \prime} \mathrm{N}, 111^{\circ} 23^{\prime} \mathrm{W}$

NW $1 / 4 \mathrm{Sec} .13, \mathrm{~T} 20 \mathrm{~S}$, R9E.

Commodities: W (minor product); $\mathrm{Au}, \mathrm{Ag}, \mathrm{Pb}, \mathrm{Zn}, \mathrm{Cu}$ (occurrence).

Ore Materials: Wolframite, scheelite, pyrite, galena, sphalerite,

Deposit Description: chalcopyrite.

Small, narrow, lensing, branching in a vein, underground workings.

Geology: Mineralization in Cretaceous andesite.

Production: Yes, late 1930 's 10,000 pounds of picked tungsten concentrates produced.

References: U.S.G.S., 1972, CRIB Mineral Resources file 12, Record 1618, p. 4220-4222; Stipp et al., 1967;

Keith, 1974.

104. La Guijas Gold Placers

Location:

Sec. 25, T20S, R9E,

Sec. $30,31,32$, T2OS, R10E.

Commodities: Au (major); $\mathrm{Ag}, \mathrm{Hg}$ (minor).

Deposit Description:

Placer deposit, fine gold with few nuggets.

Geol ogy:

In gravels on pediment slopes, old terraces or

"mesas", and in various gulches and washes along Las Guijas Wash at or near true or false bedrock. Often admixed with $\mathrm{cl}$ ay.

Production: $\quad 1,000 \mathrm{oz}$. Au, some Ag.

References: Keith, 1974; Johnson, 1972.

105. Silver Giant Mine

Location: NE $1 / 4 \mathrm{Sec} .10, \mathrm{~T} 16 \mathrm{~S}$, R5E.

Commodities: $\mathrm{Ag}$ (major); $\mathrm{Cu}$ (minor).

Deposit Description:

Quartz vein along fracture zone.

Geology: Quartz vein cuts Cretaceous-Tertiary quartz monzonite.

Production: $\quad$ Few tons of ore averaging $19 \mathrm{oz} . \mathrm{Ag} / \mathrm{T}$.

References: Keith, 1974.

\section{Known Prospects, Mineralized Areas, and Geothermal Resources with No Recorded Production}

10. Roadside Mine

Location:

$32^{\circ} 02^{\prime} 43^{\prime \prime} \mathrm{N}, 111^{\circ} 30^{\prime} 33^{\prime \prime} \mathrm{W}$,

$W$ cen. Sec. 11, T16S, R8E.

Commodities: $\mathrm{Cu}, \mathrm{Ag}$ (main commodities); $\mathrm{Au}, \mathrm{Hg}$ (minor commodities).

Ore Materials: Native copper, copper carbonates, copper oxides, sulfides, tetrahedrite, schwatzite, cinnabar and

Deposit Description: native mercury.

Small, streaks in a disseminated/shear zone. Oxidation to 800 feet. Underground, shaft workings.

Geology: Mineralization in Mesozoic andesitic volcanics and 
( 
arenitic sediments associated with

aplitic-pegmatitic quartz monzonite. Along the fault the zone is cut by cross-fracture zones.

Production: None.

References: $\quad$ U.S.G.S., 1979, CRIB Mineral Resources file 12, Record 1162, p. 3026-3028; Stipp et al., 1967;

Keith, 1974.

\section{El Conquistadors Claims}

Location: $\quad 31^{\circ} 58^{\prime} 26^{\prime \prime} \mathrm{N}, 111^{\circ} 30^{\prime} 16^{\prime \prime} \mathrm{W}$

Commodity: U.

Ore Materials: Unknown.

Deposit Description:

Smal1, NE trending, $20^{\circ} \mathrm{SE}$ dipping, pegmatite deposit, surface workings.

Geology:

Mineralization in Cretaceous-Tertiary biotite

References: U.S.G.S., 1979, CRIB Mineral Resources file 12, Record 1175, p. 3065-3067.

24. Lobos Group

Location:

$31^{\circ} 38^{\prime} 39^{\prime \prime} \mathrm{N}, 111^{\circ} 40^{\prime} 18^{\prime \prime} \mathrm{W}$

Sec. 31, T20S, R7E.

Commodities: $U$ (major commodity); Cu (minor commodity).

Ore Materials: Euxenite, secondary uranium minerals.

Deposit Description:

Small, vein/disseminated, surface workings.

Geology: Mineralization in Cretaceous-Tertiary quartzite (schist) associated with Tertiary aplite-andesite dikes (hornfels).

Production: None.

References: $\quad$ U.S.G.S., 1979, CRIB Mineral Resources file 12, Record 1267, p. 3337-3339.

43. Mego nos. 1 and 2 prospects

Location: $\quad 31^{\circ} 58^{\prime} 50^{\prime \prime} \mathrm{N}, 111^{\circ} 41^{\prime} 39^{\prime \prime} \mathrm{W}$

Commodity: W.

Sec. 11, T17S, R6E.

Ore Materials: Scheelite.

Deposit Description:

Geology:

Small, surface workings.

Production: None.

References: $\quad$ U.S.G.S., 1972, CRIB Mineral Resources file 12, Record 1523, p. 3932-3934.

\section{Calvert Prospects}

Synonym Name: Terry Marie nos. 1 and 2 Prospects.

Location:

$31^{\circ} 57^{\prime} \mathrm{N}, 111^{\circ} 41^{\prime} 14^{\prime \prime} \mathrm{W}$

Commodity: Sec. 13, T17S, R6E.

Ore Materials: Unknown.

Deposit Description: 
.

6 
Sma 11, $N 70^{\circ} \mathrm{W}$ trending, located in a shear zone, surface workings.

Geology: Mineralization in Cretaceous quartzite associated with thin aplite dikes, formation is somewhat schistose, feldspathic quartzitic rock.

Production: None.

References: U.S.G.S., 1972, CRIB Mineral Resources file 12, Record 1526, p. 3941-3943.

47. Cable and Gajewski Claim

Location: $\quad 31^{\circ} 56^{\prime} 10^{\prime \prime} \mathrm{N}, 111^{\circ} 41^{\prime} 12^{\prime \prime} \mathrm{W}$

Commodity: $\quad W$.

Sec. 24, T17S, R6E.

Ore Materials: Unknown.

Deposit Description:

Smail, N75 E trending, $75^{\circ}$ SE dipping, located in a shear zone, surface workings.

Geology: Mineralization in Mesozoic metamorphic rock.

Production: None.

References: U.S.G.S., 1972, CRIB Mineral Resources file 12, Record 1527, p. 3944-3945; Stipp et a1., 1967.

53. Linda Claim

Location:

$31^{\circ} 54^{\prime} 50^{\prime \prime} \mathrm{N}, 111^{\circ} 39^{\prime} 38^{\prime \prime} \mathrm{W}$

SeC. 29, TITS, R7E.

Commodity:

W.

Ore Materials: Molybdenum bearing scheelite.

Deposit Description:

Geology:

Production:

Sma11, deposit type unknown.

References:

Unknown.

None.

U.S.G.S., 1972, CRIB Mineral Resources file 12, Record 1533, p. 3961-3962.

62. Circle Claims

Location:

Commodity:

$31^{\circ} 43^{\prime} 08^{\prime \prime} \mathrm{N}, 111^{\circ} 35^{\prime} 37^{\prime \prime} \mathrm{W}$

Sec. 2, T2OS, R7E.

Ore Materials: Wolframite, sparse scheelite, some pyrite.

Deposit Description:

Smail, 10-20 $\mathrm{W}$ dipping, vein consists of a dull white quartz, surface workings.

Geology:

Steep sides of Schaffer Canyon consist of a faulted complex of siliceous sedimentary beds and volcanic rocks, intruded by dikes of acidic to intermediate composition.

Production: None.

References: U.S.G.S., 1972, CRIB Mineral Resources file 12, Record 1615, p. 4212-4214.

64. Utah Prospect

Location:

$31^{\circ} 39^{\prime} 29^{\prime \prime} \mathrm{N}, 111^{\circ} 35^{\prime} 53^{\prime \prime} \mathrm{W}$

Commodity:

Sec. 26, T20S, R7E.

Ore Materials: Unknown. 
$C$

( 
Deposit Description:

Small, located in a tactite zone, surface and underground workings.

Geology: Mineralization in Mesozoic silicified limestone.

Production: None.

References: U.S.G.S., 1972, CRIB Mineral Resources file 12, Record 1617, p. 4218-4219.

66. Unnamed Silica (industrial) Occurrence

Location: Sec. 33, T18S, R7E.

Comodity: Si.

Production: Unknown.

References: McCrory and O'Haire, 1965; Stipp et al., 1967.

67. Unnamed Mercury Occurrence

Location: Sec. 17, T20S, R10E.

Commodity: $\mathrm{Hg}$.

Production: Unknown.

References: Stipp et al., 1967.

68. Unnamed Silver and Copper Occurrence

Location: Sec. 13, T16S, R5E.

Commodity: $\mathrm{Ag}, \mathrm{Cu}$.

Production: Unknown.

References: $\quad$ Stipp et al., 1967.

69. Unnamed Mineral Occurrence

Location: Sec. 23, T16S, R5E.

Commodity: Unknown.

Production: Unknown.

References: Stipp et al., 1967.

70. Unnamed Silver and Gold Occurrence

Location: Sec. 11, T21S, R9E.

Commodities: $\mathrm{Ag}, \mathrm{Au}$.

Production: Unknown.

References: Stipp et al., 1967.

71. Unnamed Copper Occurrence

Location: Sec. 14, T16S, R6E.

Commodity: Cu.

Production: Unknown.

References: $\quad$ Stipp et al., 1967.

72. Unnamed Tungsten Occurrence

Location: Sec. 13, T16S, R6E.

Commodity: W.

Production: Unknown.

References: Stipp et al., 1967.

73. Unnamed Tungsten and Copper Occurrence

Location: Sec. 36, T20S, R9E.

Commodities: $\quad W, \mathrm{Cu}$.

Production: Unknown.

References: $\quad$ Stipp et al., 1967. 
$\sigma$

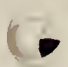


74. Unnamed Mineral Occurrence
Location:
Sec. 35, T20S, R9E.
Commodity:
Unknown.
Production:
Unknown.
References:
Stipp et al., 1967.

75. Unnamed Gold, Copper and Silver Occurrence

Location: Sec. 14, T16S, R8E.

Commodities: $\mathrm{Au}, \mathrm{Cu}, \mathrm{Ag}$.

Production: Unknown.

References: $\quad$ Stipp et al., 1967.

76. Unnamed Manganese Occurrence
Location:
Commodity:
Sec. 13, T16S, R8E.
Production:
$\mathrm{Mn}$.
References:
Unknown.
Stipp et a1., 1967.

77. Unnamed Mineral Occurrence
Location:
Commodity:
Sec. 26, T20S, R9E.
Production:
Unknown.
References:
Unknown.
Stipp et a7., 1967.

78. Unnamed Molybdenum Occurrence
Location:
Commodity:
Sec. 32, T16S, R8E.
Production:
Mo.
References:
Unknown.
Stipp et al., 1967.

79. Unnamed Lead Occurrence
Location:
Commodity:
Sec. 35, T16S, R5E.
Production:
$\mathrm{Pb}$.
References:
Unknown.
Stipp et al., 1967.

80. Unnamed Mineral Occurrence
Location:
Commodity:
Sec. 12, T20S, R9E.
Production:
Unknown.
References:
Unknown.
Stipp et al., 1967.

81. Unnamed Tungsten Occurrence
Location:
Commodity:
Sec. 23, T20S, R6E.
Production:
W.
Unknown.
References:
Stipp et al., 1967.

82. Unnamed Tungsten Occurrence
Location:
Commodity:
Sec. 33, T20S, R7E.
Production:
W.
References:
Unknown.
Stipp et al., 1967. 
.

6 
83. Unnamed Uranium Occurrence

Location: $\quad$ Sec. 21, T20S, R7E.

Commodity: $\quad U$.

Production: Unknown.

References: $\quad$ Stipp et al., 1967.

84. Unnamed Tungsten Occurrence

Location: Sec. 26, T17S, R6E.

Commodity: W.

Production: Unknown.

References: $\quad$ Stipp et al., 1967.

85. Unnamed Mineral Occurrence

Location: $\quad$ Sec. 7, T20S, R8E.

Commodity: Unknown.

Production: Unknown.

References: $\quad$ Stipp et a1., 1967.

86. Unnamed Fluorite Occurrence

Location: Sec. 5, T17S, R10E.

Commodity: $\quad F$.

Production: Unknown.

References: $\quad$ Stipp et al., 1967.

87. Unnamed Mineral Occurrence

Location: $\quad$ Sec. 9, T18S, R7E.

Commodity: Unknown.

Production: Unknown.

References: $\quad$ Stipp et a1., 1967.

88. Unnamed Manganese Occurrence

Location: Sec. 21, T18S, R7E.

Commodity: $\quad M n$.

Production: Unknown.

References: $\quad$ Stipp et al., 1967.

89. Unnamed Mineral Occurrence

Location: Sec. 34, T20S, R7E.

Commodity: Unknown.

Production: Unknown.

References: $\quad$ Stipp et a1., 1967.

90. Unnamed Mineral Occurrence

Location: Sec. 29, T20S, R7E.

Commodity: Unknown.

Production: Unknown.

References: $\quad$ Stipp et a1., 1967.

91. Windy Claims

Location:

Sec. 24, T18S, R7E.

Commodity:

Be.

Ore Materials: Beryl.

Deposit Description:

Vein.

Geology: Beryl in 3 foot thick quartz veins cutting granite. 
c.

( 
Production: Unknown.

References: $\quad$ Stipp et a1., 1967; Arizona Bureau of Mines, 1969.

92. Contreras Canyon

Location: $\quad$ Sec. 30, T18S, R8E.

Commodity: Be.

Ore Materials: Beryl.

Deposit Description:

Geology: $\quad$ Bein. $\quad$ Bery in quartz vein intrusive into granite.

Production: Unknown.

References: $\quad$ Stipp et a1., 1967; Arizona Bureau of Mines, 1969.

93. Unnamed Gold Occurrence

Location: Sec. 31, T19S, R9E.

Commodity: Au.

Production: Unknown.

References: Stipp et a1., 1967.

94. Unnamed Tungsten Occurrence

Location: $\quad$ Sec. 23, T19S, R8E.

Comodity: W.

Production: Unknown.

References: $\quad$ Stipp et al., 1967.

95. Unnamed Mineral Occurrence

Location: $\quad$ Sec. 31, 32, T19S, R8E.

Commodity: Unknown.

Production: Unknown.

References: Stipp et al., 1967.

96. Unnamed Mineral Occurrence

Location: Sec. 28, T20S, R7E.

Commodity: Unknown.

Production: Unknown.

References: Stipp et al., 1967.

97. Unnamed Mineral Occurrence

Location: Sec. 23, T20S, R7E.

Commodity: Unknown.

Production: Unknown.

References: Stipp et al., 1967.

98. Unnamed Silver and Gold Occurrence

Location: Sec. 12, T19S, R7E.

Commodities: $\mathrm{Ag}, \mathrm{Au}$.

Production: Unknown.

References: Stipp et al., 1967.

99. Unnamed Mineral Occurrence

Location: Sec. 16, T20S, R7E.

Commodity: Unknown.

Production: Unknown.

References: Stipp et a1., 1967. 
$\sigma$ 
100. Unnamed Tungsten Occurrence
Location:
Sec. 1, T20S, R7E.
Cormodity:
W.
Production:
Unknown.
References:
Stipp et a1., 1967.

101. Unnamed Mineral Occurrence
Location:
Sec. 13, T20S, R7E.
Commodity:
Unknown.
Production:
Unknown.
References: Stipp et al., 1967.

102. Unnamed Manganese Occurrence
Location:
Commodity:
Sec. 3, T20S, R7E.
Production:
$\mathrm{Mn}$.
References:
Unknown.
Stipp et al., 1967.

103. Unnamed Mineral Occurrence
Location:
Commodity:
Sec. 17, T20S, R7E.
Production:
Unknown.
References:
Unknown.
Stipp et a1., 1967.

106. Unnamed Bismuth Occurrence

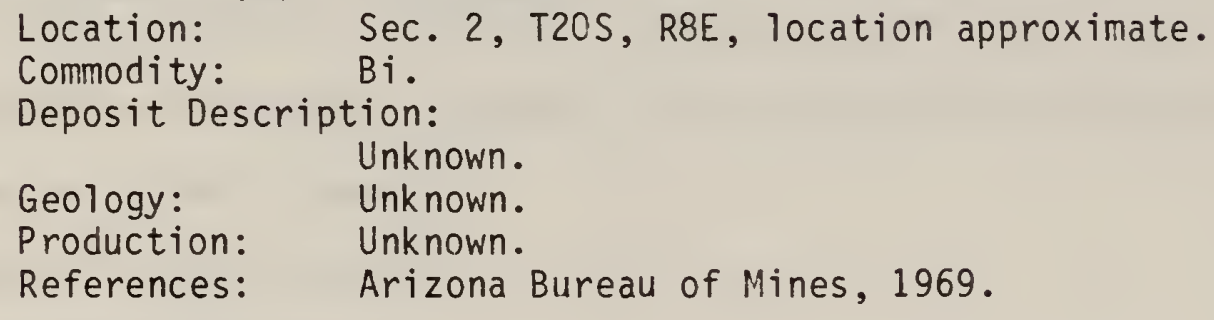

107. Gismo Group

Location: Sec. 5, T21S, R10E.

Commodities: U (major commodity); $\mathrm{Cu}, \mathrm{Fe}$ (minor commodities).

Ore Materials: Uraninite, kasolite, schroekingerite.

Deposit Description:

Fault-fissure vein.

Geology: In granite.

Production: Unknown.

References: Peirce et al., 1970.

\section{Mining Claims, Leases, and Material Sites}

There are numerous mining claims within the Kitt Peak GRA. According to the BLM records (as of June, 1982), in the Coyote Mountains WSA and surrounding area, the highest density of claims is in the northern part of the WSA. North of the WSA are 31 patented claims. There is one patented claim within the Baboquivari Peak South WSA (commodities unknown), and one 
co 
adjacent to the southern end of the WSA. There are two patented claims west of this WSA, also. The claim density, i.e., the number of claims per square mile (section), is shown in figure 6 and more detailed records are included in table 2 .

In spite of our efforts, we were unahle to determine the specific types of deposits or mineral commodities for which these claims were filed.

Within the Kitt Peak GRA there are two silica sites which lie to the east of the Baboquivari Peak South WSA (59 and 66). To the authors' knowledge there are no other materials sites within the GRA that are near or within the two WSAs.

\section{Mineral Deposit Types}

Geological environments to be considered as potentially favorable for the occurrence of mineral or energy resources include the following:

Paleozoic and Mesozoic sediments and metamorphosed equivalents, Mesozoic plutonic rocks,

Mesozoic volcanic rocks,

Laramide intrusive rocks,

Mid-Tertiary metamorphic rocks,

Mid-Tertiary volcanic rocks,

Mid-Tertiary sediments,

Late Tertiary sediments, and

Recent alluvium.

Geologic environments and associated mineral deposit types are shown in table 3.

\section{Paleozoic and Mesozoic Sediments}

Paleozoic and Mesozoic sedimentary rocks in southern Arizona have been considered potentially favorable for accumulation of hydrocarbons, especially 
G

6 
$\rightarrow \mathrm{Ag}_{3} 106$

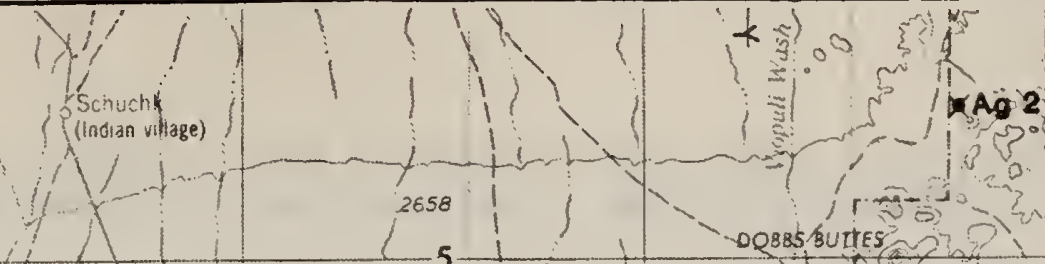

$\mathrm{AO}^{2} 2$

Sons

ris

31 Pat. Claims $493 \mathrm{mw} / \mathrm{m}$

$4 \mathrm{Cu} 3$

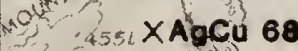

Cu $71 \times \quad \times W 72$

rountao

$r^{2} ?^{2}$

(6)

Au 4 1 69

$\times$ Aus 5

Aú 9.

$8 \times \mathrm{Pb} 79$

A4, 12

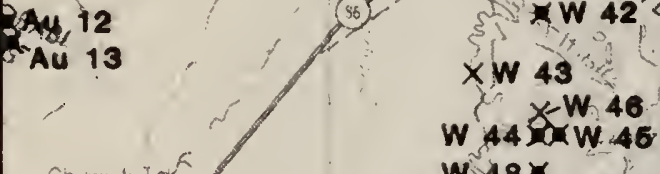

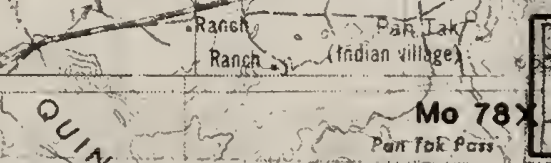

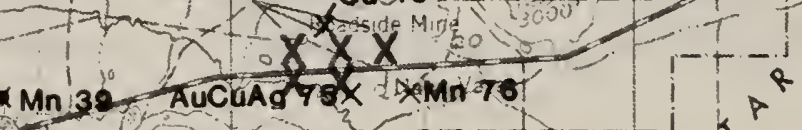

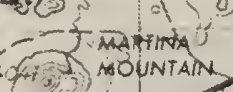
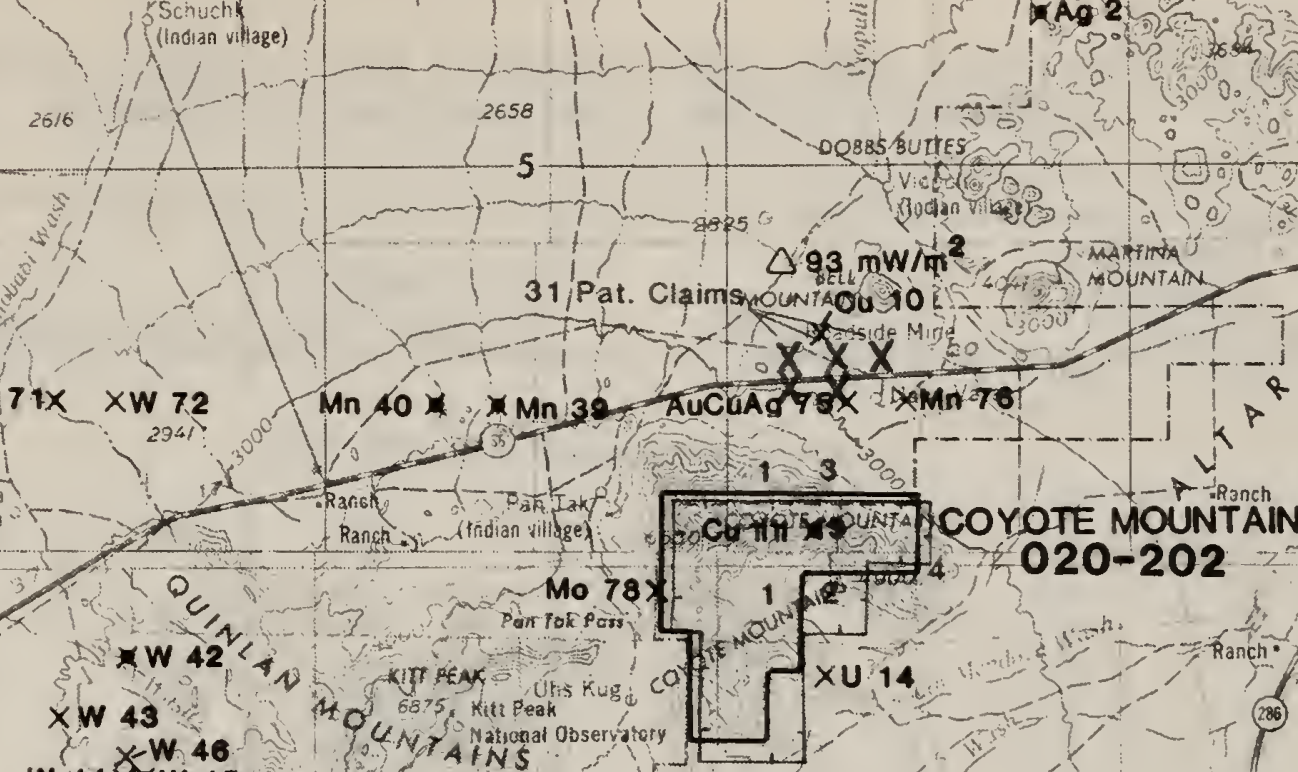

Y 5 .

W 44 S W 45

$w 48 x \times w 40$

$w 50$

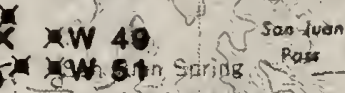

W $55 \div$ W 52

W 56 W-54XW 57
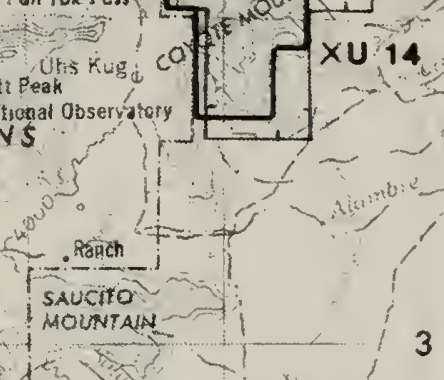

14

F 86 x

$=32^{\circ}$

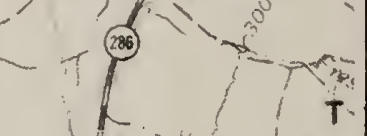

75

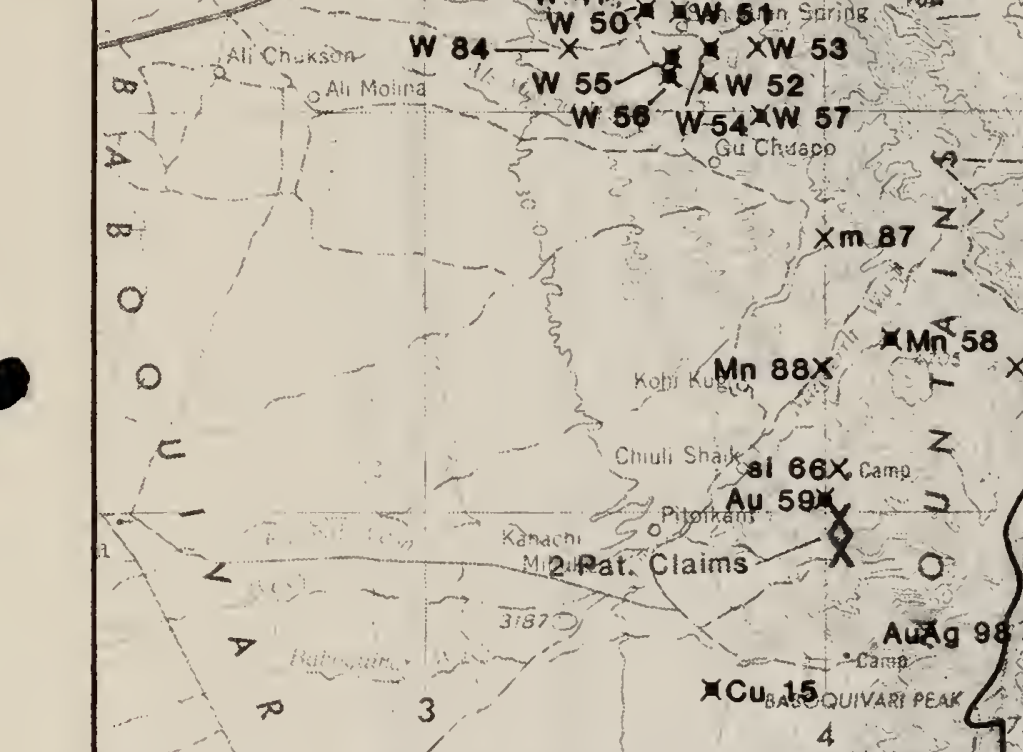

15.

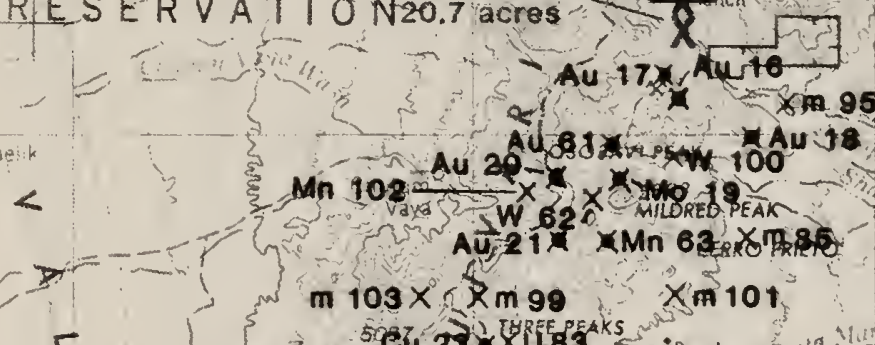

Au 17 Avis

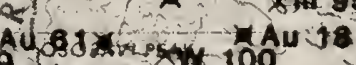

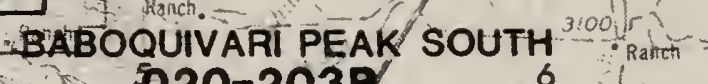

020-203B
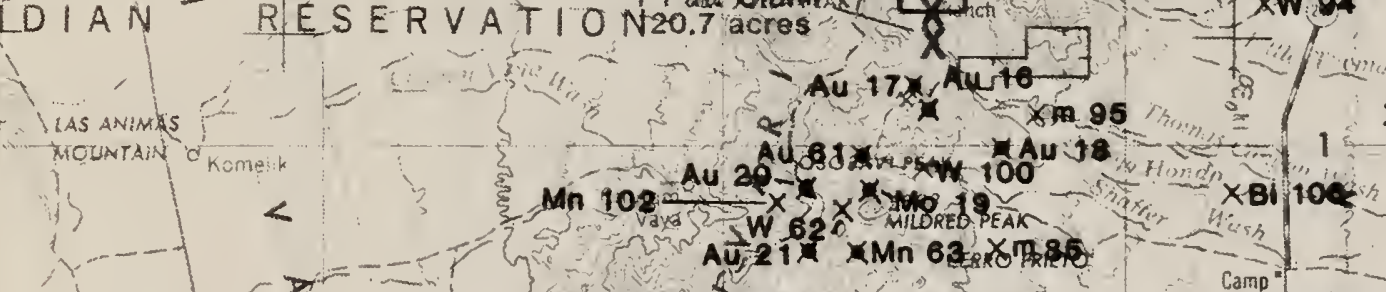

(t)

-

\section{$x w 81$}

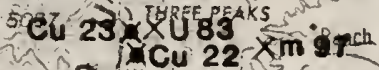

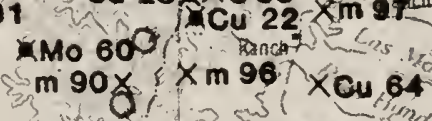

m

$\prec-27 \$ 6$

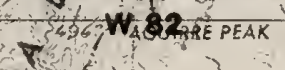

$\circ$

$111^{\circ} 45^{\prime}$ R $6 E$

R TE

R 8 E $111^{\circ} 30^{\circ}$

XAu 93

$\times B i f 100$

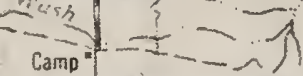

La Guktas Gold Placers

W65 $\mathrm{Ag} 2 \mathrm{Ag}^{2} \times$

$x \operatorname{mon}$

Figure 6 CLAIM DENSITY MAP, WITH OIL AND GAS LEASING STATUS, OF THE KITT PEAK AREA, ARIZONA.

Note: hachured lines are oil and gas leases; numbers are claims per section. 

TABLE 2

CLAIM DENSITY RECORDS IN THE WILDERNESS STUDY AREAS (WSA), KITT PEAK GRA ACCORDING TO BLM (JUNE 1982), ARIZONA STATE OFFICE
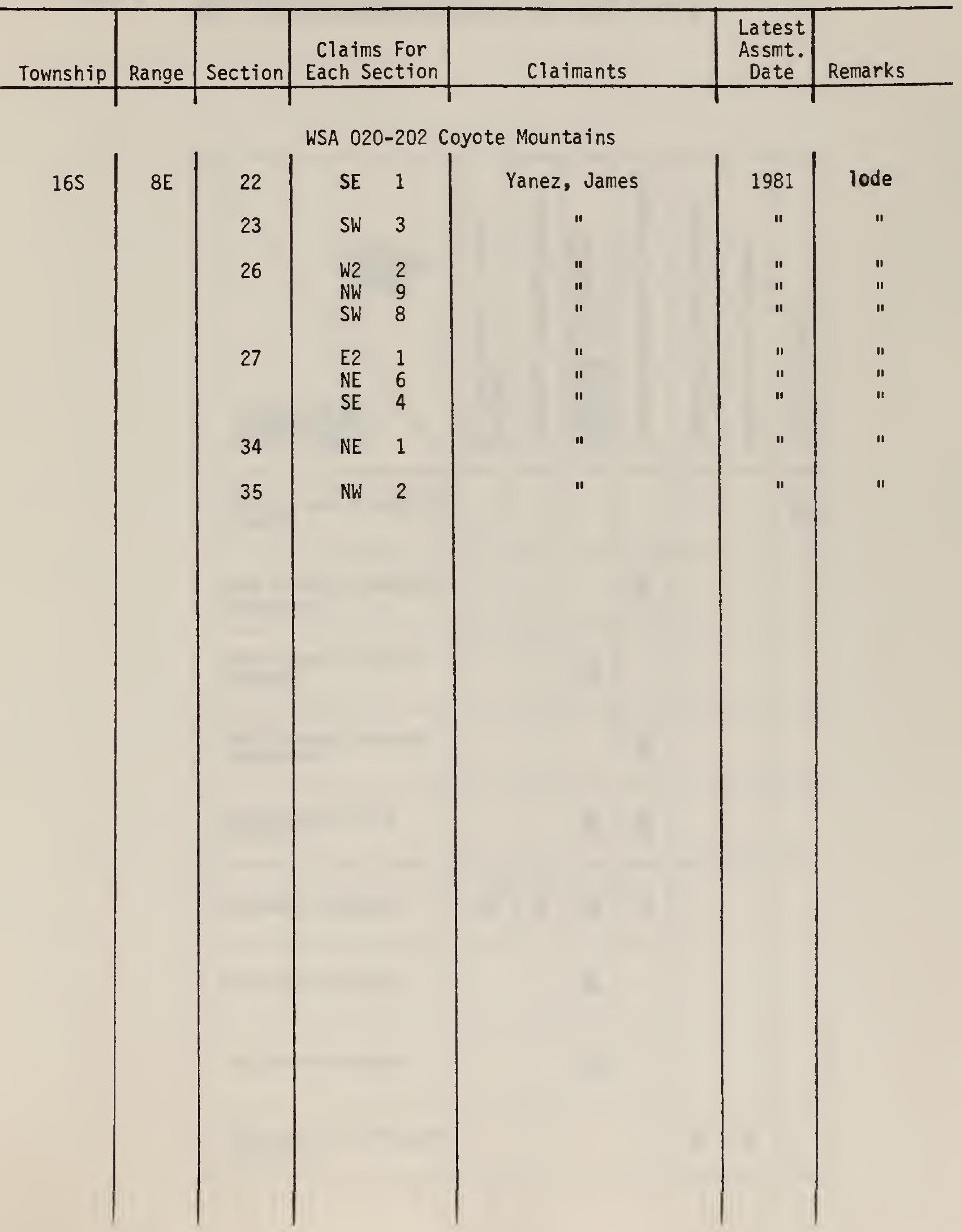
Table 3. GEOLOGICAL ENVIROMENTS OF THE KITT PEAK AREA AND ASSOCIATED MINERAL DEPOSIT TYPES

\begin{tabular}{|c|c|c|c|c|c|c|c|}
\hline $\begin{array}{l}\text { MINERAL } \\
\text { DEPOSIT } \\
\text { TYPE } \\
\text { GEOLOGICAL } \\
\text { ENVIROMENT - } \\
\text { HOST ROCKS }\end{array}$ & 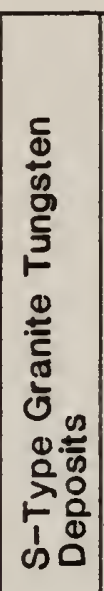 & 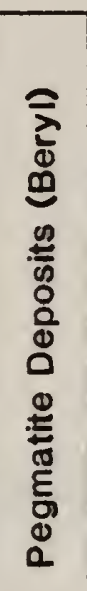 & 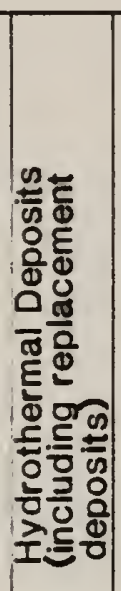 & 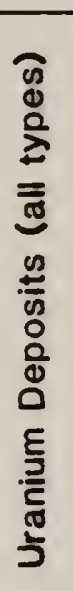 & 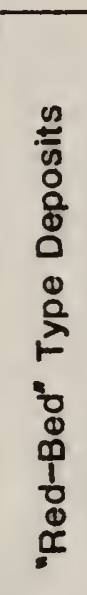 & 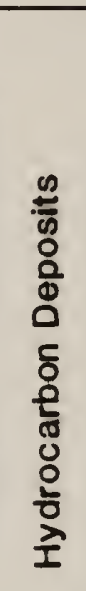 & $\begin{array}{l}\frac{n}{0} \\
\frac{0}{0} \\
\frac{0}{0} \\
0 \\
\frac{\Phi}{0} \\
\frac{\pi}{0}\end{array}$ \\
\hline $\begin{array}{l}\text { Tertiary and Quaternary } \\
\text { Alluvium }\end{array}$ & & & & & & & $\mathbf{X}$ \\
\hline $\begin{array}{l}\text { Late Tertiary Basin-Fill } \\
\text { Sediments }\end{array}$ & & & & $\mathbf{X}$ & & & \\
\hline $\begin{array}{l}\text { Mid-Tertiary Volcanic } \\
\text { Deposits }\end{array}$ & & & $\mathbf{X}$ & & & & \\
\hline $\begin{array}{l}\text { Mid-Tertiary Basin-Fill } \\
\text { Sediments }\end{array}$ & & & & $\mathbf{x}$ & & & \\
\hline $\begin{array}{l}\text { Metamorphic Core } \\
\text { Complex }\end{array}$ & & & $\mathbf{X}$ & $\mathbf{X}$ & & & \\
\hline Laramide Intrusives & $\mathbf{X}$ & $\mathbf{X}$ & $\mathbf{X}$ & $\mathbf{x}$ & & & \\
\hline Mesozoic Volcanics & & & $\mathbf{X}$ & & & & \\
\hline Mesozoic Intrusives & & & $\mathbf{X}$ & & & & \\
\hline $\begin{array}{l}\text { Paleozoic and Mesozoic } \\
\text { Sediments }\end{array}$ & & & & & $\mathbf{X}$ & $\mathbf{X}$ & \\
\hline
\end{tabular}





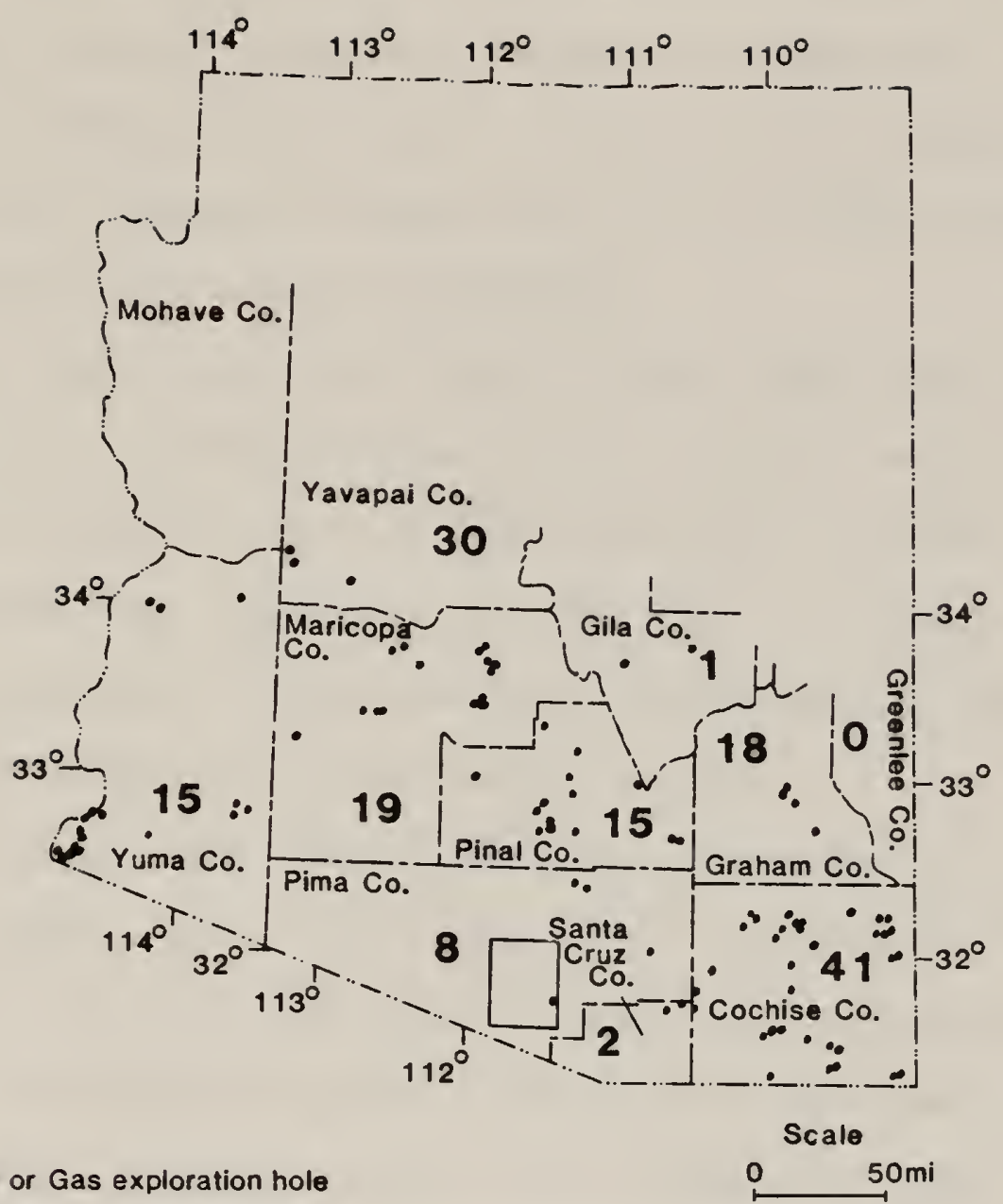

- Oil or Gas exploration hole

15 Number of holes in county

FIG.7 LOCATION OF OIL AND GAS EXPLORATION HOLES IN SOUTHERN ARIZONA, after Jones (1979). 
those sediments located in the Overthrust Belt (Peirce, 1982; Keith, 1980). All exploration holes drilled in the area to date, however, have been dry (Peirce, 1979; Keith, 1981; Peirce, 1982; see fig. 7). In the Kitt Peak GRA one dry well has been drilled in the southeastern part of the GRA (see fig. 7). The Phillips Petroleum Project and exploration geologists for southeastern Arizona feel there is little to no oil potential in the Kitt Peak GRA (J.N. Anderson and others, pers. comm., 1982), they have found that the crystalline rocks extend to great depth.

Mesozoic red beds within the GRA are potentially favorable for the occurrence of red-bed-type copper-silver deposits such as are present in Permian and Triassic rocks in central and northern New Mexico (LaPoint, 1979, $1974 \mathrm{a}, 1974 \mathrm{~b})$. No occurrences of this type are known, but red-beds are present in the central region near and in the Baboquivari Peak South WSA, and metamorphosed redbeds are present south of the WSA.

The Paleozoic and Mesozoic sedimentary rocks may act as host rocks for tungsten, copper, silver, gold, lead and zinc in metamorphic or hydrothermal ore deposits in which the fluids and metals were derived during dehydration reactions accompanying prograde metamorphism as described by Hutchinson and others (1980). Numerous tungsten and polymetallic deposits are hosted in Mesozoic sediments near and related to Laramide plutonism.

\section{Mesozoic Plutonic Rocks}

During the mid-Jurassic, a magmatic arc extended across the Kitt Peak GRA (Dickinson, 1981; see fig. 2A). Porphyry copper mineralization is associated with Jurassic igneous rocks at Bisbee east of the GRA; and according to Titley (1982), the Jurassic represents a metallogenic epoch in the southwest warranting exploration. However, there is no known porphyry mineralization within the area. Jurassic granitic plutons and Mesozoic 
diorites are responsible for at least five gold or gold-silver hydrothermal deposits within the $\operatorname{GRA}(5,13,36,37$ and 41$)$. These deposits are primarily gold-silver deposits, but in two copper is also present ( 13 and 41 ), and in one (37) lead is present.

\section{Mesozoic Volcanic Rocks}

Mesozoic volcanic rocks in southern Arizona are associated with gold-silver and base metal lode deposits, these are hosted primarily in Cretaceous intermediate and silicic volcanics within the GRA $(26,288,29$, 39, 63 and 65). The polymetallic deposits may be hydrothermal deposits related to the Cretaceous volcanism, or they may be hosted in the volcanics but deposited during the Laramide plutonic activity. There are two manganese deposits (40, northwest of the Coyote Mountains WSA, and 58, northwest of the Baboquivari Peak South WSA) hosted in the volcanics. Hewett and Fleischer (1960), in a regional study of manganese oxide vein deposits, concluded that most were formed from hydrothermal fluids associated with late stages of volcanic activity; it is likely that these deposits are of a similar nature. A small amount of manganese ore has been produced from these two deposits.

\section{Laramide Intrusive Rocks}

The Laramide was a time of emplacement of all but one (Bisbee) of the porphyry deposits in Arizona and adjacent New Mexico and Mexico. Of the 35 major porphyry copper deposits in this region, 32 lie to the southeast of the Holbrook Line where basement is Pinal Schist, and 3 lie to the northwest where basement consists of the Yavapai Series and gneissic-metavolcanic terrain (see fig. 2). The intrusives associated with the porphyry copper deposits were emplaced during the westward sweep of the magmatic arc (Clark et al., 1982; Damon et al., 1981) and possibly related to the decrease in the dip of the Benioff zone at this time (Coney and Reynolds, 1980). The 
0

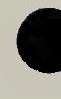

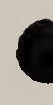


porphyry copper deposits appear to be aligned along northwest and east-northeast trends (see fig. 2; Heidrick and Titley, 1982). The northwesterly trend is sub-parallel to Mesozoic linear discontinuities in depositional patterns (Titley, 1976); the trend of Laramide basement-cored uplifts and thrust faults (Nielsen, 1979; Davis, 1981); the Texas zone of Schmitt (1966); and the trend of the Laramide magmatic arcs. The ENE trend is sub-parallel to Precambrian fold axes and to Laramide tensional features (Rehrig and Heidrick, 1976). The intrusions related to the porphyry copper deposits are small in area (seldom over $3 \mathrm{~km}^{2}$ ) and may have been emplaced along the NW and ENE structural intersections (Titley, 1981). None of the major northwest or east-northeast trends of porphyry copper deposits pass through the GRA, but porphyry copper deposits do ring the northern margin of the GRA (Wright and Haxel, 1982; Haxel et al., 1980). The Laramide rocks are host to or genetically related to numerous gold-silver, base metal and tungsten deposits of metamorphic or hydrothermal origin, but porphyry deposits within the GRA are not known.

The reason for the apparent lack of porphyry copper deposits within the GRA are not known, but could be the result of one or more of the following factors:

1. There are no Precambrian rocks within the GRA; whereas all of the porphyry copper deposits of the southwest contain Precambrian basement.

2. Most of the Laramide intrusives in this area are peraluminous and probably S-type granites. These are generally not associated with porphyry copper-molybdenum-gold deposits but rather with tin-tungsten deposits (Burnham, 1981).

3. Erosion during post-Laramide time may have progressed to deep levels removing the shallower portions of intrusives. The 
•

-

- 
presence of muscovite in several of the intrusives suggests that the level of exposure is indeed deep. The presence of tungsten mineralization also supports a relatively deep level of exposure because, as shown by Newberry and Einaudi (1981), tungsten skarns typically form at deep levels.

In light of the above discussion, it is considered that the GRA overall has a low favorability for the occurrence of porphyry copper deposits.

Silver-gold and base metal deposits are commonly hosted in Cretaceous sediments or volcanics, as are numerous tungsten deposits, and appear to be of either metamorphic or hydrothermal origin, formed during devolitilization of the pluton during cooling, or dewatering of the country rock during metamorphism. The majority of these deposits occur south of the Baboquivari Peak South WSA and southwest of the Coyote Mountains WSA.

Two beryl occurrences $(91$ and 92$)$ are present north of the Baboquivari Peak South WSA, in a northwesterly trending belt of Laramide pegmatites. These beryl-bearing pegmatites may extend southward into the WSA.

The Laramide S-type granites may also be a source rock for uranium. There is one uranium occurrence (107) in a vein deposit within Laramide granite; another uranium occurrence (14) just southeast of the coyote Mountains WSA may be related to Laramide pegmatites. Three uranium occurrences $(22,24$, and 83$)$ are hosted by Cretaceous sediments or schists; two of these are associated with Laramide granite, the third (83) is probably associated with Laramide granite.

\section{Mid-Tertiary Metamorphic Rocks}

The potential for mineral deposits associated with metamorphic core complexes is not well known as it is only during the last decade or so that the complexes themselves have been widely recognized. In an important work, 
-

-

- 
Coney and Reynolds (1980) and several co-workers attempted to assess uranium favorability of these complexes; and in so doing, they have also provided useful information on some other elements. Some important findings of this study, which also includes the report by Keith and Reynolds (1980), are as follows:

1. Uranium related to plutonic processes tends to be associated with potassium-rich rocks $\left(\mathrm{K}_{2} \mathrm{O}>4 \%\right)$.

2. Uranium related to metamorphic processes may be transported by fluids released through dehydration reactions. Geochemical studies by Keith and Reynolds (1980) show that mylonitization is not associated with any changes in $U$ or Th concentration. However, the rich uranium deposit of Graeber Lease in the Kettle metamorphic core complex, Washington, occurs in mylonitic gneisses and may be of metamorphic origin (Reynolds, 1980).

3. The dislocation surface and the underlying chloritic breccia represent a permeable horizon along which fluids migrated (Reynolds, 1980). Geochemical studies of metamorphic core complexes in the Rawhide Mountains in southwestern Arizona by Keith and Reynolds (1980) show that these rocks are enriched in $\mathrm{U}, \mathrm{Th}, \mathrm{Cu}, \mathrm{Zn}, \mathrm{Fe}, \mathrm{V}, \mathrm{Li}$, and $\mathrm{Cr}$ compared to the protolith, and contain uranium occurrences and more widespread hematite, limonite, $\mathrm{Cu}$, and $\mathrm{Au}$ mineralization. Coney and Reynolds (1980) consider that investigation of these zones downdip into the nearby basins may be worthwhile.

If the rocks of the Coyote Mountains do represent part of a metamorphic core complex, then there is potential for uranium, copper and gold mineralization in the area around the Ajo Road Fault. 
-

-

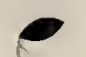




\section{Mid-Tertiary Volcanics}

In southern Arizona, southwestern New Mexico and Mexico, mid-Tertiary volcanics are very common, and contain gold-silver and base metal lode deposits (Damon et a1., 1981; Clark et al., 1982). The volcanics were erupted when the magmatic arc swept rather rapidly westward, possibly as a result of the steepening of the Benioff zone (Coney and Reynolds, 1977). In southwestern New Mexico, the deposits are associated with cauldrons from which voluminous ignimbrites and other volcanics were erupted (Elston, 1978). As yet, no such cauldrons have been positively identified in southern Arizona, but the voluminous ignimbrites and existing numerous deposits suggest that such cauldrons could be present.

The mid-Tertiary volcanic rocks within the GRA crop out along the western side of the Baboquivari and Quinlan Mountains and in the eastern and northeastern parts of the GRA. They range in composition from andesite to rhyolite, and include intrusives, flows and a variety of tuffs.

There is only one deposit which can be directly related to the Tertiary volcanics (59). It represents a late stage hydrothermal vein deposit containing gold, silver, copper, lead and manganese mineralization, and crops out east of the Baboquivari Peak South WSA.

\section{Mid-Tertiary Sediments}

Mid-Tertiary valley-fill sediments are widespread in southern Arizona, and since the discovery of the Anderson Mine (Sherborne et al., 1979) have become a prime target for uranium exploration.

In order to form a uranium deposit by the agency of circulating groundwater, or connate water, it is necessary to have adequate uranium source rocks, permeable sediments for the water to flow through, and a reductant to precipitate the uranium. Potentially suitable source rocks 
1 
within the GRA are the S-type Laramide granites and pegmatites, the Mesozoic and Tertiary volcanics and the chloritic breccias and detachment zone near the Ajo Road Fault. Suitable reductants may be present in conglomerates or fossil geothermal systems. There are no known active geothermal systems near either WSA.

\section{Late Tertiary Sediments}

Late Tertiary sediments are present in all basins formed as a result of Basin and Range faulting. The depths of these basins are indicated by contours shown in figure 3 and interpreted from gravity data by Oppenheimer and Sumner (1981). As in the case of the mid-Tertiary sediments, adequate source rocks are widespread, and permeable horizons are present. It is not known if extensive organic reductants are present within these sediments. Reducing geothermal waters are not prevalent in the area. There are no uranium occurrences to the authors' knowledge in the late Tertiary sediments.

\section{Recent Alluvium}

Aluvium formed in present day river valleys and pediments is a possible site for concentrations of placer gold and other heavy minerals.

Within the GRA, there are four placer deposits. A tungsten placer deposit (25) and a gold, silver and mercury placer deposit (104) are present in the southeastern corner of the GRA. Two gold placer deposits are also present, one is present south of the Baboquivari Peak South WSA (18); the other (12) is present near the western border of the GRA, west of the Coyote Mountains WSA. The two placers in the southeastern corner of the GRA, in the Las Guijas Mountains, produced the most. 1,000 ounces of gold and some silver was mined at site 104 (Las Guijas Gold Placers), and a few tons of wolframite concentrate has been produced from site 25 (Las Guijas Tungsten Placers). 
-

-

• 


\section{Active Geothermal Systems}

To the authors' knowledge, there are no geothermal wells or springs within the GRA. There is a low temperature geothermal field to the east of the GRA that crosses into the GRA in the vicinity of the Black Hills.

\section{Mineral Economics}

The assessment of the geological, energy and mineral resources favorability should rely upon not only geology, but must also be concerned with economic factors and priorities. Discovery, recovery, cost of production of the resource from sources with varying qualities and/or concentrations are included in those considerations. Special consideration must be given to the strategic and critical minerals and metals. As this project is of limited scope, and because of special difficulties in southwestern Arizona, economic analyses of various commodities can only be discussed briefly.

Some factors especially important to the evaluation of the mineral and energy resources of southwestern Arizona include the following:

1. The geology of the Kitt Peak GRA is very complex and detailed information on the geology and mineral deposits of the WSAS is, in part, limited. This is multiplied by recent and ongoing reinterpretations of the geology of the Basin and Range in Arizona. in order to interpret the geology of the WSAs, and thus be able to project the types of mineral deposits that may be present in those areas, it is necessary to apply information about known areas of apparently similar geology to the interpretation of the geology of the WSAs. A wide variety of possibilities must be considered and, therefore, discussions of mineral economics must be considered 
-

-

○ 


\section{tentative.}

2. Contributing to the problems listed above, and creating some other distinct difficulties, are the ruggedness and roadless nature of the WSAs. Roadlessness, a criterion for WSAs, inhibits exploration and development of mineral resources due to poor access, distance to market, and other factors which increase the expense and difficulty of geological and mineral exploration.

3. A great number of commodities, including strategic and critical minerals and metals, are known to occur in the WSAs and their surrounding areas.

4. Considering all the above mentioned problems, it is very possible that sophisticated methods currently used by professional geologic explorationists have not been fully employed in southwestern Arizona. Most of the mines and occurrences in the GRA were discovered many years ago by prospectors using simple techniques.

Gold and molybdenum are the only non-strategic metals found in the two WSAs. The future demand for both these commodities is quite dependent on worldwide economic conditions. If the economy rebounds, molybdenum should make a comeback. Gold, however, will increase in value if economic conditions decline.

There has been much recent speculation about the potential for oil and gas occurrences in the Basin and Range of southern Arizona. It has been suggested that the Overthrust Belt, related to $0 i 1$ occurrences from Canada to Utah, extends into Arizona as a wide NW-SE trending belt curling around the Colorado Plateau in the Basin and Range area (Peirce, 1982; Anschutz, 1980 ). The theory states that around $60 \mathrm{~m} \cdot \mathrm{y} \cdot \mathrm{B} . \mathrm{P}$. older crystalline rocks thrust over 
-

-

- 
younger, possibly oil-rich, strata (Peirce, 1982). The complex structures, including Basin and Range faults, found in southern Arizona coupled with the high temperatures created by igneous activity since that time dim the possibility of preservation of $0 i 1$ and gas. Peirce (1982) states if the Overthrust Belt exists, or ever has existed, in Arizona, geolgic complexity obscures it and drilling has not yet resolved the issue. Anschutz (1980) suggests that the Overthrust Belt could become the most important oil and gas province to be discovered in th last 20 to 30 years, but also states that it is one of the most difficult and expensive areas to explore and develop. Phillips Petroleum Co. geologists in charge of oil exploration for this part of southern Arizona now feel chances for oil and gas discoveries are minimal (J.N. Anderson and others, pers. comm.).

\section{Strategic and Critical Minerals and Metals}

The strategic metal silver occurs in both WSAs. Zinc, lead and copper also occur in the Coyote Mountain WSA. Beryllium and tungsten could also occur in the WSAs.

Zinc has a variety of industrial applications, the most important being zinc-base alloy die castings, galvanizing iron and steel products, and brass production. Much of the lead used in the United States is consumed in the manufacture of storage batteries and as a gasoline additive, although use in gasoline is not as important as it once was. Use in ammunition and solder is also important, increasingly so during wartime. More silver is consumed in photography in the United States in one year than this country produces during that time (Brobst and Pratt, 1973). Tungsten, which in addition to use in steel and chemicals, also enjoys use in non-ferrous alloys and as tungsten carbide. Copper, although considered a strategic and critical metal, occurs in abundance in Arizona. 
-

-

- 
In summary, it must be noted that the Kitt Peak GRA contains a large number of mineral occurrences and many different commodities. Deposits of strategic and critical commodities, some of which have produced, are known to occur in the WSAs and surrounding parts of the GRA. Further exploration could lead to the discovery of potentially important deposits in the GRA and WSAs.

THE GEOLOGY, ENERGY AND MINERAL RESOURCES

OF THE WILDERNESS STUDY AREAS

In this section the individual WSAs are discussed with respect to physiography, geology, mineral occurrences, resources potential and recommendations for further work. The classification of resource potential and level of confidence is according to the scheme provided by the Bureau of Land Management (attachment 9, dated March 24, 1982) and given below. Classification of resources within and surrounding the WSAs of the Kitt Peak GRA is summarized in figures 8 through 10 .

\section{Classification Scheme}

1. The geologic environment and the inferred geologic processes do not indicate favorability for accumulation of mineral resources.

2. The geologic environment and the inferred geologic processes indicate low favorability for accumulation of mineral resources.

3. The geologic environment, the inferred geologic processes, and the reported mineral occurrences indicate moderate favorability for accumulation of mineral resources.

4. The geologic environment, the inferred geologic processes, the reported mineral occurrences, and the known mines or deposits 
-

-

- 

Au 104 
-

-

- 


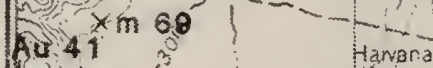

QAú 9

$x \rightarrow P B D>9$

Powit?

Au 13

Adas 68

cut $71 x-x w_{2947} 72$.

Mn $40 \times$ un 20 AuCuAa $75 x$ d\%

$\int_{k}^{+}$

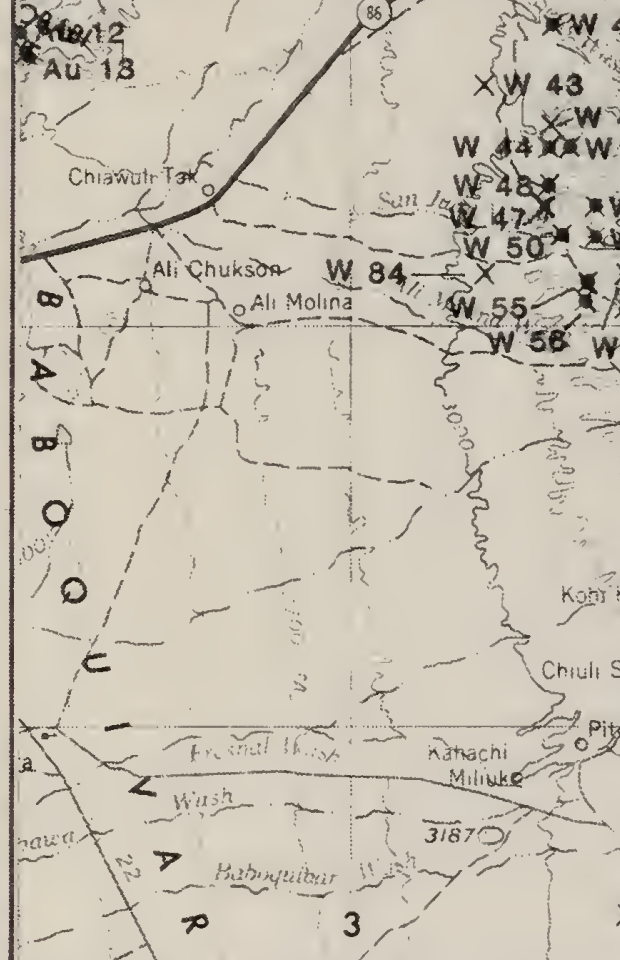

31. IDIAN - RIESERVATION

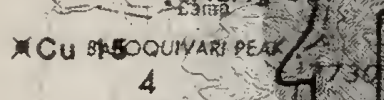
0 ests kut unak Unt do $1+4-3-B$

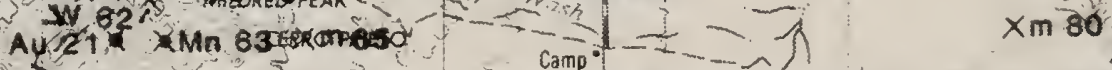

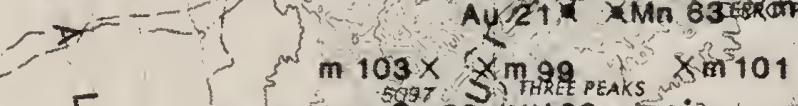

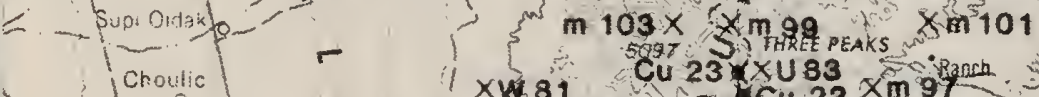

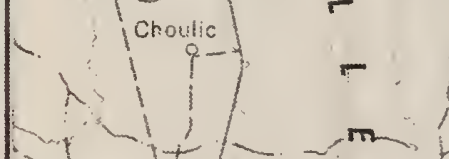
$x+81$

Mi 60 O Cu $22 \times m 97$

m $90 \%$ र

$x \cup 64$ X $40 \times 89$

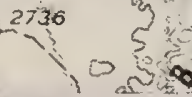

TTण 45 P $6 E$

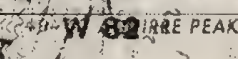

R TE

R $8 \mathrm{E}$ Tन $30^{\circ}$

La güili Gold Placers

$+65 \times \mathrm{Ag} 26$ 
-

-

$\ldots$

- 


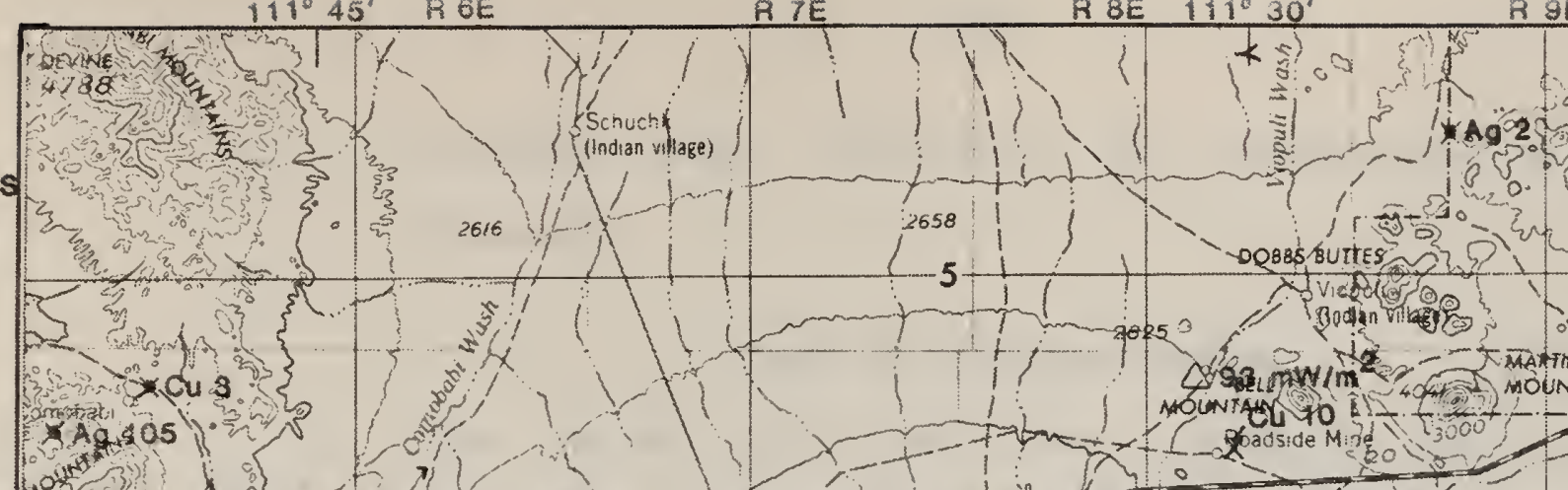

A TE

Q gE

$T 168$

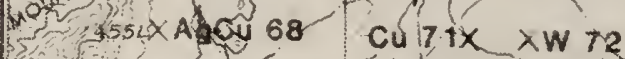

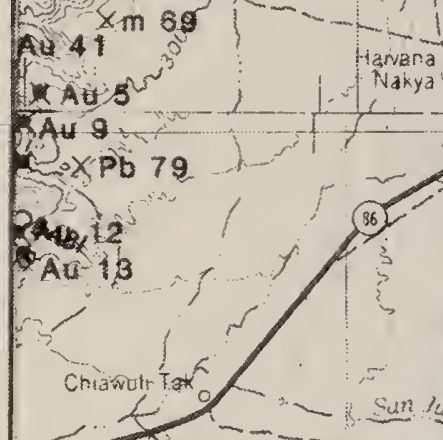

- Ali chuksor W

( $34-15$

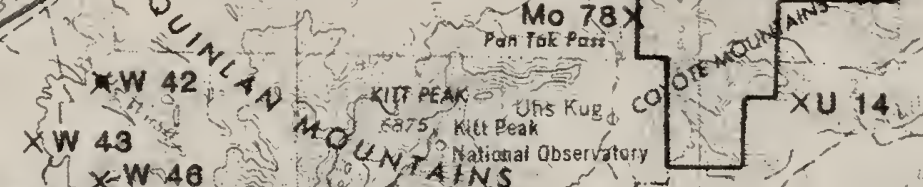

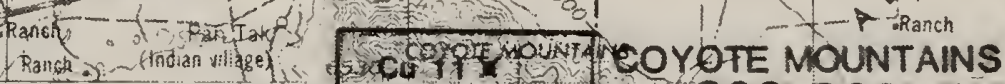

W A4 CXW WE

12 $48 x$

1 47 . 4 ह

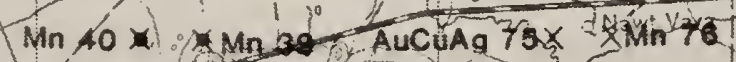

and 1

$15 S$

$x^{2} \mid$ i

Nat

$\$$

8 
-

- 
indicate high favorability for accumulation of mineral resources.

\section{Level of Confidence Scheme}

A. The available data are either insufficient and/or cannot be considered as direct evidence to support or refute the possible existence of mineral resources within the respective area.

B. The available data provide indirect evidence to support or refute the possible existence of mineral resources.

c. The available data provide direct evidence but are quantitatively minimal to support or refute the possible existence of mineral resources.

D. The available data provide abundant direct and indirect evidence to support or refute the possible existence of mineral resources.

\section{The Coyote Mountains WSA (020-202)}

\section{Physiography}

The WSA lies in the Coyote Mountains at the northern end of the Baboquivari range. The topography is mostly mountainous with the northeast corner having gentler slopes. Maximum relief in the WSA is about 3500 feet.

\section{Geology}

Jurassic granitic rocks are the oldest rocks in the Coyote Mountains WSA. In the southern part of the WSA, the Jurassic intrusives consist of hornblende- and/or biotite-bearing granodiorite; monzonite and monzogranite; and syenogranite. In the northeast part of the WSA are Jurassic sphene- and epidote-bearing hornblende-biotite quartz diorite, hornblende-epidote diorite 
-

-

- 
and augite hornblendite. In fault contact with the Jurassic rocks are dacitic flows and interbedded mudstone, siltstone, sandstone, conglomerate and breccia of the Mesozoic Roadside Formation, and a small outcropping of Cretaceous (?) Sand Wells sediments, including subordinate volcanics. Garnet-two-mica granites, aplite dikes and extensive pegmatites of the 58 m.y.B.P. Pan Tak Granite crop out over much of the WSA. Much of the pluton has been regionally metamorphosed; the older phases were affected by Laramide metamorphism and pegmatites and Paleozoic sediments of the northern Coyote Mountains underwent penetrative deformation during the mid-Tertiary orogeny. There is sound evidence that rocks of the Coyote Mountains are a metamorphic core complex. In addition to the above-mentioned mid-Tertary ductile deformation, the rocks in the vicinity of the Ajo Road Fault or Decollement, which runs through the eastern half of the WSA, are mylonitized and chloritic breccia underlies the fault near the northern border of the western part of the WSA. Upper plate rocks of the Roadside and Sand Wells Formations are shattered, sheared, faulted and gouged.

Quaternary alluvium underlies the northeast corner of the coyote Mountains WSA.

\section{Mineral Deposits}

One mineral deposit ( $C$ U 11) lies within the WSA and another occurrence (Mo 78) lies at the western boundary. A uranium occurrence (U 14) is located near the southeastern edge of the WSA.

The Bonanza Mine ( $\mathrm{Cu} 11$ ) is a small, high-grade pyrometosomatic deposit in metamorphosed Paleozoic limestone. Mineralization is associated with the intrusion of the Laramide Pan Tak Granite. The Bonanza Mine produced copper and silver and possibly gold, zinc and molybdenum; the mine yielded 700 tons of ore between 1909 and 1951. Mineralogy is pyrite, chalcopyrite, bornite, 
-

-

- 
covellite, chalcocite, molybdenite and sphalerite. Carrigan (1971) reports that other small replacement deposits occur in metamorphosed limestone and copper oxides are found along igneous-sedimentary contacts. Prior to 1928, ore mined averaged $10 \% \mathrm{Cu}$ and $1.5 \mathrm{oz}$. Ag/ton (Carrigan, 1971).

Mo 78 is an unnamed molybdenum occurrence for which no information is available. It is located in the Pan Tak Granite.

The El Conquistadors Claims ( $U$ 14) are uranium claims located in pegmatites of the Pan Tak Granite. NURE fieldwork failed to find mineralization in the area (Luning and Brouillard, 1982).

Several mineral deposits and occurrences are located in Mesozoic sediments and volcanics that are possibly the upper plate of a metamorphic core complex and mineralization may be related to that event.

\section{Land Classification for GEM Resources Potential \\ Metallic Minerals}

The part of the WSA underlain by the Laramide Pan Tak Granite and metasediments, Mesozoic diorites, and hornblendite, Mesozoic volcanics and sediments (area 1, fig. 8), all of which may be part of a metamorphic core complex, is classified as moderately favorable for the occurrence of metallic minerals at a confidence level of B. Metallics specifically considered in this classification are $\mathrm{Cu}, \mathrm{Ag}, \mathrm{Au}, \mathrm{Zn}, \mathrm{Mo}, \mathrm{Hg}, \mathrm{W}$ and $\mathrm{Sn}$.

The reasons for this classification are as follows:

1. A past producer of copper and silver ( $\mathrm{Cu} 11)$ is located in Laramide metasediments of the WSA. Additionally, a molybdenum occurrence is located in the Pan Tak Granite at the western boundary of the WSA.

2. Numerous tungsten occurrences, many of them past producers, are associated with Laramide S-type garnet-two-mica granites, 
-

-

e 
similar to the Pan Tak Granite, of the Quinlan, Comobabi, Baboquivari and Las Guijas Mountains. Tin is also often associated with S-type granites.

3. If the Coyote Mountains are indeed a metamorphic core complex, then mineralization may occur in the mylonitic zone (northern part of the Coyote Mountains) adjacent to the Ajo Road Fault, along the fault, and in the fractured and shattered upper plate rocks. Copper, silver, manganese, gold and mercury indeed occur in heavily fractured Roadside Formation rocks of the "upper plate" in areas north of the WSA.

4. Conversely, remobilization of elements in Laramide-age deposits may have occurred during the mid-Tertiary orogeny, leaving much of the WSA barren.

The southern part of the WSA, underlain by Jurassic monzonite, granodiorite, monzogranite and syenogranite (area 2 , fig. 8 ) is considered to be of low favorability for the occurrence of metallic minerals. Reasons for this classification are:

1. Few mineral occurrences in the GRA are related to the Jurassic intrusives and none of these occurrences are in or near the WSA.

2. The Jurassic granitic rocks are not good hosts for younger mineralization.

\section{Uranium}

The area around occurrence $U 14$ (area 4, fig. 9) is classified as moderately favorable for uranium at a confidence level of $B$. Reasons include:

1. A uranium occurrence (14) is reported in pegmatites of the Pan 
-

- 
Tak Granite in this area.

2. NURE workers were unable to locate this deposit; perhaps there is no mineralization. However, many uranium occurrences reported in the Nogales quadrangle were not visited or not found during the NURE study. It is possible that attempts to locate this and other occurrences were not thorough.

The rest of the Coyote Mountains WSA north of the contact between Jurassic monzonites and associated intrusives and Laramide Pan Tak Granite (area 5, fig. 9) is of low favorability for the occurrence of uranium at a confidence level of $B$. The reasons for this classification are as follows:

1. Pegmatites are al so located in this area.

2. Mylonites and chloritic breccias of core rocks, and upper plate rocks of other metamorphic core complexes are known to contain anomalously high levels of $U$ and other elements, and uranium deposits.

3. However, no occurrences are reported in rocks of this part of the WSA.

\section{Other Resources}

The WSA is considered unfavorable for the occurrence of other resources.

\section{The Baboquivari Peak South WSA (020-203B)}

\section{Physiography}

The Baboquivari Peak South WSA lies in the central Baboquivari Mountains. Slopes are quite steep and the total relief of the WSA is approximately 3100 feet.

\section{Geology}

The WSA is underlain by rocks ranging in age from early Jurassic to 
-

-

- 
Laramide. The oldest rocks are rhyodacitic to andesitic volcanics and interbedded quartzite, arkose and conglomerate of the Ali Molina Formation. Conformably overlying the Ali Molina rocks are the redbeds and intermediate volcanic flows of the Pitoikam Formation. The Mulberry Wash Volcanic Formation unconformably overlies the Pitoikam Formation and consists of latitic and rhyodacitic to andesitic flows, tuffs, and volcanic breccias, conglomerate, arkose, shale, mudstone, marl and limestone. All three units are early Jurassic in age and the three units underly most of the WSA lunit Mzs, see fig. 3). The very westernmost part of the WSA is underlain by the Jurassic Baboquivari Granite, a coarse-grained, reddish, porphyritic granite, which is in fault contact with the older Jurassic rocks. The late Jurassic or Cretaceous Chiuli Shaik Formation overlies the Jurassic pluton in the western part of the WSA; the northern extension of the contact between the two units is a fault. The Chiuli Shaik Formation consists of andesite flows, breccias, rhyolitic tuffs, and sub-volcanic intrusions. The youngest rocks in the WSA, potentially beryl-bearing Laramide pegmatites, crop out in the northern tip of the WSA and are intrusive into the early Jurassic volcanics and sediments. Sections of two major faults are located in the western part of the WSA (see fig. 3 ).

\section{Mineral Deposits}

An unamed silver and gold occurrence (AuAg 98) is located in the central western part of the Baboquivari Peak South WSA and apparently is in the late Mesozoic Chiuli Shaik volcanics. The Iowana Mine (Au 16) and the Jupiter Mine (Au 17) are located less than two miles south of the WSA. Both are past producers of gold and silver and averaged 16 and $12 \mathrm{oz}$. $\mathrm{Ag}$ per ton, respectively. Lead, copper and zinc sulfides, and wolframite also occur. The hydrothermal mineralization is related to Laramide dikes. Occurrence 98 
0

0

- 
may be similar.

Two beryl occurrences, the Windy Claims ( $\mathrm{Be} 91)$ and Contreras Canyon (Be 92) are located close to the northern end of the WSA, and the beryl-bearing pegmatite underlies the northern corner of the WSA.

\section{Land Classification for GEM Resources Potential}

\section{Metallic Minerals}

The entire WSA (area 3 , fig.8) is classified as moderately favorable for the occurrence of metallic minerals at a confidence level of $B$. The reasons for this classification are as follows:

1. One gold and silver occurrence is located within the WSA and several others are located a few miles to the south of the WSA occur in rocks that also underlie the WSA.

2. However, little is known about the single mineral occurrence in the WSA.

3. Potentially favorable geologic environments are found in the WSA, including Mesozoic volcanic rocks and Laramide intrusives, which could be related to hydrothermal mineralization, and Mesozoic sediments, including red beds and limestones, which could host red bed type copper + silver and pyrometasomatic replacement deposits, respectively. A Tertiary intrusive of unknown nature lies immediately west of the WSA and could also be a source of metallic minerals.

\section{Uranium}

The entire WSA (area 5, fig. 9) is of low favorability for the occurrence of uranium resources. The reasons are as follows:

1. No uranium mineralization is reported to occur in the WSA. However, 
0

○

- 
2. Two uranium occurrences are located to the south in metamorphosed equivalents of Mesozoic sediments and volcanics which crop out in the WSA.

3. Laramide pegmatites, which crop out at the northern end and surround the eastern edge of the WSA, could be good sources of uranium.

\section{Non-metallic Minerals}

Areas in and around the WSA which are underlain by Laramide-age pegmatites (area 6, fig. 10) are classified as moderately favorable for the occurrence of non-metallic minerlas, specifically beryl, at a confidence level of $C$. The reasons are:

1. Two beryl occurrences are located in Laramide pegmatites near the northern corner of the WSA. One (Be 92) is less than a mile from the WSA.

2. Beryl could occur in other areas where the same pegmatites crop out.

\section{Other Resources}

The WSA is considered unfavorable for the occurrence of other resources.

Recommendations for Further Work:

Coyote Mountains HSA (020-202) and

Baboquivari Peak South WSA (020-203B)

For areas 1 (Coyote Mountains WSA) and $\underline{3}$ (Baboquivari Peak South WSA), it is recommended that field-checking for the presence of extensive hydrothermal alteration be performed.

Additionally, for area 1 it is recomended that the dislocation surface (Ajo Road Fault), and underlying chloritic breccia and mylonite be sampled for geochemistry and analysed for $\mathrm{Cu}, \mathrm{Au}, \mathrm{Ag}, \mathrm{Zn}, \mathrm{Fe}, \mathrm{V}, \mathrm{Li}, \mathrm{Cr}, \mathrm{U}$ and $\mathrm{Th}$ to 
0

○

- 
check for enrichment.

occurrence $U 14$ in area 4 should be visited and checked for uranium mineralization and higher than normal levels of radiation. If mineralization and/or high radiation levels are encountered, a detailed descriptin of the geology of the area should be done.

For areas 4,5 and 6 , pegmatites should be checked for the occurrence of rare non-metallic minerals such as beryl. In addition, if significant uranium indications are encountered in area 4 , area 5 should be checked for similar geologic environments. 
0

○

- 


\section{REFERENCES}

Anschutz, P.F., 1980, The overthrust belt: Will it double U.S. gas reserves?: World 0i1, January 1980, p. 111-116.

Arizona Bureau of Mines, 1969, Mineral and water resources of Arizona: Arizona Bureau of Mines Buletin 180,638 p.

Arizona Department of Mineral Resources, 1981, Directory of active mines in Arizona: Arizona Department of Mineral Resources Open-File Report D-13(81), $21 \mathrm{p}$.

Brobst, D.A. and Pratt, W.P., 1973, United States Mineral Resources: U.S. Geological Survey Professional Paper 820, $722 \mathrm{p}$.

Bryant, D.L., 1968, Diagnostic characteristics of the Paleozoic formations of southeastern Arizona, in Titley, S.R., ed., Southern Arizona Guidebook III: Arizona Geological Society, p. 33-47.

Burchfiel, B.C., 1979, Geologic history of the central western United States, in Ridge, J.D., ed., Papers on mineral deposits of western North America: Nevada Bureau of Mines and Geology Report 33, p. 1-12.

Burnham, W.C., 1981, Physiochemical constraints on porphyry mineralization, in Dickinson, W.R., and Payne, W.D., Relations of tectonics to ore deposits in the southern Cordillera: Arizona Geological Society Digest, vol. 14, p. 7177 .

Carrigan, F.J., 1971, A geologic investigation of contact metamorphic deposits in the Coyote Mountains, Pima County, Arizona (M.S. thesis): Tucson, University of Arizona, $67 \mathrm{p}$.

Chappel1, B.W., and White, A.J.R., 1974, Two contrasting granite types: Pacific Geology, vol. 8, p. 173-174.

Clark, K.F., Foster, C.T., and Damon, P.E., 1982, Cenozoic mineral deposits and subduction related magmatic arcs in Mexico: Geological Society of America Bulletin, v. 93, p. 533-544.

Coney, P.J., 1980, Cordilleran metamorphic core complexes - An overview: Geological Society of America Memoir 153, p. 7-31.

Coney, P.J., and Reynolds, S.J., 1980, Cordilleran metamorphic core complexes and their uranium favorability: U.S. Department of Energy Open-File Report GJBX-258(80).

Coney, P.J., and Reynolds, S.J., 1977, Cordilleran Benioff zones: Nature, v. 270 , p. 403-406.

Cooper, J.R., 1971, Mesozoic stratigraphy of the Sierrita Mountains, Pima County, Arizona: U.S. Geological Survey Professional Paper 658-D, $42 \mathrm{p}$.

Damon, P.E., and Mauger, R.L., 1966, Epeirogeny - orogeny viewed from the basin and Range Province: Transactions of the American Institute of Mining, Metallurgical and Petroleum Engineers, v. 235, p. 99-112. 
•

-

- 
Damon, P.E., Shafiqullah, M., and Clark, K.F., 1981, Age trends of igneous activity in relation to metallogenesis in the southern Cordillera, in Dickinson, W.R. and Payne, W.D., eds., Relations of tectonics to ore deposits in the southern Cordillera: Arizona Geological Society Digest, v. 14, p. 137-154.

Davis, G.H., 1981, Regional strain analysis of the superposed deformations in southwestern Arizona and the eastern Great Basin, in Dickinson, W.R. and Payne, W.D., eds., Relations of tectonics to ore deposits in the southern Cordillera: Arizona Geological Society Digest, v. 14, p. $155-172$.

Davis, G.H., Anderson, J.L., Frost, E.G., and Shackelford, T.J., 1980, Mylonitization and detachment faulting in the Whipple - Buckskin Rawhide Mountains terrain, southeastern California and western Arizona, in Crittendon, M.D. Jr., Coney, P.J., and Davis, G.H., Cordilleran metamorphic core complexes: Geological Society of America Memoir 153, p. 79-129.

Davis, G.H., and Coney, P.J., 1979, Geologic development of Cordilleran metamorphic core complexes: Geology, v. 7, p. 120-124.

Davis, G.H., Gardulski, A.F., and Anderson, T.H., 1981, Structural and structural-petrological characteristics of some metamorphic core complex terranes in southern Arizona and northern Sonora, in Ortlieb, Luc, and Roldau Q., Jaime, eds., Geology of northwestern Mexico and southern Arizona: Hermosillo, Sonora, Mexico, Estacion Regional del Noroeste Instituto de Geologia, U.N.A.M., Geological Society of America Cordilleran Section Metting Fieldtrip Guidebook, p. 323-365.

Dickinson, W.R., 1981, Plate tectonic evolution of the southern Cordillera, in Dickinson, W.R. and Payne, W.D., eds., Relations of tectonics to ore deposits in the southern Cordillera: Arizona Geological Society Digest, v. 14 , p. $113-135$.

Eberly, L.D. and Stanley, T.B. Jr., 1978, Cenozoic stratigraphy and geologic history of southwestern Arizona: Geological Society of America Bulletin, v. 89, p. 921-940.

Elston, W.E., 1978, Mid-Tertiary cauldrons and their relationship to mineral resources, southwestern New Mexico: A brief review: New Mexico Geological Society Special Publication 7, p. 107-113.

Elston, W.E. and Bornhorst, T.J., 1979, The Rio Grande rift in context of regional post-40 m.y. volcanic and tectonic events, in Riecker, R.E., ed., Rio Grande rift: Tectonics and magmatism: American Geophysical Union, p. 416-438.

Fenneman, H.M., 1931, Physiography of western United States: New York, McGraw-Hill, 534 p.

Fair, C.L., 1965, Geology of the Fresnal Canyon area, Baboquivari Muntains, Pima County, Arizona (PhD dissertation): Tucson, University of Arizona, $89 \mathrm{p}$. 
-

0

• 
Gardulski, A.F., 1980, A structural and petrologic analysis of a quartzite-pegmatite tectonite, Coyote Mountains, southern Arizona (M.S. thesis): Tucson, University of Arizona, $69 \mathrm{p}$.

Haxel, Gordon, Wright, J.E., May, D.J., and Tosdal, R.M., 1980, Reconaissance geology of the Mesozoic and lower Cenozoic rocks of the southern Papago Indian Reservation, Arizona: A preliminary report, in Jenney, J.P., and Stone, Claudia, eds., Studies in western Arizona: -Arizona Geological Society Digest, v. 12, p. 14-29.

Heidrick, T.L., and Titley, S.R., 1982, Fracture and dike patterns in Laramide plutons and their structural and tectonic implications, in Titley, S.R., ed., Advances in geology of the porphyry copper deposits:Tuscon, The University of Arizona Press, p. 73-91.

Heindl, L.A., 1965, Mesozoic formations in the Comobabi and Roskruge Mountains, Papago Indian Reservation, Arizona: U.S. Geological Survey Bulletin 1194-H, $15 \mathrm{p}$.

Heindl, L.A., and Fair, C.L., 1965, Mesozoic(?) rocks in the Baboquivari Mountains, Papago Indian Reservation, Arizona: U.S. Geological Survey Bulletin 1194-I, 12 p.

Heindl, L.A. and McClymonds, N.E., 1964, Younger Precambrian formations and the Bolsa quartzite of Cambrian age, Papago Indian Reservation, Arizona: U.S. Geological Survey Professional Paper 501-C, p. C43-C49.

Hewett, D.F. and Fleischer, M., 1960, Deposits of manganese oxides: Economic Geology, v. 55, p. 1-55.

Hutchinson, R.W., Fyfe, W.S., and Kerrich, R., 1980, Deep fluid penetration and ore deposition: Minerals Science Engineering, v. 12, no. 3, p. 107-120.

Johnson, M.G., 1972, Placer gold deposits of Arizona: U.S. Geological Survey Bulletin $1355,103 \mathrm{p}$.

Keith, S.B., 1981, The great southwestern Arizona overthrust oil and gas play: Arizona Bureau of Geology and Mineral Technology Fieldnotes, v. 11 , no. 1, p. 1 .

Keith, S.B., 1980, The great southwestern Arizona overthrust oil and gas play: Arizona Bureau of Geology and Mineral Technology Fieldnotes, v. 10 , no. 1, p. $1-3,6-8$.

Keith, S.B., 1974, Index of mining properties in Pima County, Arizona: Arizona Bureau of Mines Bulletin 189, $156 \mathrm{p}$.

Keith, S.B., and Reynolds, S.J., 1980, Geochemistry of Cordilleran metamorphic core complexes, in Coney, P.J. and Reynolds, S.J., Cordilleran metamorphic core complexes and their uranium favorability: U.S. Department of Energy Open-File Report GJBX-258(80), p. 274-303.

LaPoint, D.J., 1979, Geology, geochemistry, and petrology of sandstone copper 
0

0 
deposits in New Mexico (PhD thesis): Boulder, University of Colorado, $333 \mathrm{p}$.

LaPoint, D.J., 1974a, Possible source areas for sandstone copper deposits at the Scholle District, central New Mexico (abs.): New Mexico Geological Society, 25 th Field Conference Guidebook, p. 305-308.

LaPoint, D.J., 1974b, Genesis of sandstone-type copper deposits at the Scholle District, central New Mexico (abs.): Geological Society of America, Abstracts with Programs, vol. 6, p. 451-452.

Lowel1, J.D., 1974, Regional characteristics of porphyry copper deposits of the southwest: Economic Geology, v. 69, p. 601-617.

Luning, R.H., and Brouillard, L.A., 1982, National uranium resource evaluation, Nogales quadrangle, Arizona: U.S. Department of Energy Open-File Report PGJ/F-130(82), $70 \mathrm{p}$.

Min, M.M., 1965, Petrography and alteration of the Kitt Peak area, Pima County, Arizona (M.S. thesis): Tucson, University of Arizona, $90 \mathrm{p}$.

McCrory, F.J. and O'Haire, R.T., 1965, Map of known non-metallic mineral occurrences of Arizona: Arizona Bureau of Mines, scale 1:1,000,000.

Newberry, R.J., and Einaudi, M.T., 1981, Tectonic and geochemical setting of tungsten skarn mineralization in the Cordillera, in Dickinson, W.R. and Payne, W.D., Relations of tectonics to ore deposits in the southern Cordillera: Arizona Geological Society Digest, vol. 14, p. 99-111.

Nielsen, R.L., 1979, Regional tectonics and the emplacement of Laramide porphyry copper intrusions - Arizona - New Mexico, in Ridge, J.D., ed., Papers on mineral deposits of western North America: Nevada Bureau of Mines and Geology Report 33, p. 49-56.

Oppenheimer, J.M. and Sumner, J.S., 1981, Gravity modelling of the basins in the Basin and Range Province, Arizona: Arizona Geological Society Digest, v. 13, p. 111-116.

Peirce, H.W., 1982, The search for petroleum in Arizona: Arizona Bureau of Geology and Mineral Technology Fieldnotes, v. 12, no. 2, p. 1-5.

Peirce, H.W., 1979, Land: Arizona Bureau of Geology and Mineral Technology Fieldnotes, vol. 9, no. 3, p. 1-7, 13.

Peirce, H.W., 1976, Elements of Paleozoic tectonics in Arizona: Arizona Geological Society Digest, v. 10, p. 37-57.

Peirce, H.W., Keith, S.B., and Wilt, J.C., 1970, Coal, oil, natural gas, helium, and uranium in Arizona: Arizona Bureau of Mines Bulletin 182, p. 289 .

Rehrig, W.A. and Heidrick, T.L., 1976, Regional tectonic stress during the Laramide and late Tertiary intrusive periods, Basin and Range Province, Arizona, in Wilt, J.C. and Jenney, J.P., eds., Tectonic Digest: Arizona Geological Society Digest, v. 10, p. 205-228. 
-

0 
Rehrig, W.A., and Reynolds, S.J., 1980, Geologic and geochronologic reconnaissance of a northwest-trending zone of metamorphic core complexes, in Coney, P.J., and Reynolds, S.J., Cordilleran metamorphic core complexes and their uranium favorability: U.S. Department of Energy Open-File Report GJBX-258(80), p. 187-246.

Reynolds, S.J., 1980, A conceptual basis for the occurrence of uranium in Cordilleran metamorphic core complexes, in Coney, P.J. and Reynolds, S.J., Cordilleran metamorphic core complexes and their uranium favorability: U.S. Department of Energy Open-File Report GJBX-258(80), p. 187-246.

Scarborough, R.B. and Wilt, J.C., 1979, A study of uranium favorability of Cenozoic sedimentary rocks, Basin and Range Province, Arizona, Part I, General geology and chronology of pre-Late Miocene Cenozoic sedimentary rocks: The University of Arizona and U.S. Geological Survey Open-File Report 79-1429.

Schmitt, H.A., 1966, The porphyry copper deposits in their regional setting, in Titley, S.R. and Hicks, C.L., eds., Geology of the porphyry copper deposits, southwestern North America: Tucson, University of Arizona Press, p. 17-33.

Shafiqullah, M., Damon, P.E., Lynch, D.J., Reynolds, S.J., Rehrig, W.A., and Raymond, R.H., 1980, K-Ar geochronology and geologic history of southwestern Arizona and adjacent areas: Arizona Geological Society Digest, v. 12, p. 201-260.

Sherborne, J.E., Buckovic, W.A., Dewitt, D.B., Hellinger, T.S., Pavlak, S.J., 1979, Major uranium discovery in volcaniclastic sediments, Basin and Range province, Yavapai County, Arizona: American Association of Petroleum Geologists Bulletin, v. 63, p. 621-646.

Silver, L.T. and Anderson, T.H., 1974, Possible left-lateral early to middle Mesozoic disruption of the southwestern North American craton margin (abs.): Geological Society of America Abstracts with Programs, v. 6, p. 955-956.

Stipp, T.F., Hargler, L.B., Alto, B.R., and Sutherland, H.L., 1967, Reported occurrences of selected minerals in Arizona: U.S. Geological Survey Mineral Investigations Resources Map MR-46, scale 1:500,000, 2 sheets.

Teichert, C., 1965, Devonian rocks and paleogeography of central Arizona: U.S. Geological Survey Professional Paper 464, $181 \mathrm{p}$.

Titley, S.R., 1982, Geologic setting of the porphyry copper deposits, in Titley, S.R., ed., Advances in geology of porphyry copper deposits: Tucson, University of Arizona Press, p. 37-58.

Titley, S.R., 1981, Geological and geotectonic setting of porphyry copper deposits in the southern Cordillera, in Dickinson, W.R. and Payne, W.D., eds., Relations of tectonics to ore deposits in the southern Cordillera: Arizona Geological Society Digest, v. 14, p. 79-97. 
○

0

e 
Titley, S.R., 1976, Evidence for a Mesozoic linear tectonic pattern in southeastern Arizona: Arizona Geological Society Digest, v. 10, p. 71-101.

Tucker, W.C.Jr., 1980, Tectonic geomorphology of the Luke Air Force range, Arizona: Arizona Geological Society Digest, v. 10, p. 71-101.

U.S. Geological Survey, 1972 (some entries revised 1979, 1981), CRIB Mineral Resources file 12, (see individual mineral deposit descriptions for record and page numbers).

Wilson, E.D., Moore, R.T., and Cooper, J.R., 1969, Geological map of Arizona: Arizona Bureau of Mines and the U.S. Geological Survey, scale 1:500,000.

Witcher, J.C., Stone, C., and Mahman, W.R., 1982, Geothermal Resources of Arizona map: Arizona Bureau of Mines and Mineral Technology, scale $1: 500,000$.

Wright, J.E., and Haxel, Gordon, 1982, A garnet-two-mica granite, Coyote Mountains, southern Arizona: Geologic setting, uranium-lead isotopic systematics of zircon, and nature of the granite source region: Geological Society of America Bulletin, v. 93, p. 1176-1188. 
-

L. 